\title{
Pais e mães das camadas populares na escola pública fundamental: a participação fragmentada
}

\section{Introdução}

Desde sua emergência no cenário público nacional no início do século passado até os dias de hoje, as camadas populares ${ }^{1}$ têm mostrado formas de participação política distintas que acompanham as transformações econômicas, sociais e políticas por que passa o país ao longo desse período.

Embora as péssimas condições de vida que experimentavam os primeiros operários no começo do século 20 tivessem projetado na cena pública os trabalhadores das nascentes indústrias, o reconhecimento das camadas populares como um novo ator político, entre outros já existentes, se dá apenas no início da década de 30, marcado por dois eventos um em âmbito mundial e outro de caráter local - que irão promover as áreas urbanas, em detrimento das áreas rurais, como o local que sintetiza as condições econômicas e políticas do conjunto do país naquela época. Com efeito, a crise de 29 - que põe fim à primazia dos interesses agrários vinculados à economia de exportação do café - e a revolução de 30 - que abala a supremacia das oligarquias rurais na sociedade brasileira dão livre curso às mudanças sociais e econômicas associadas ao desenvolvimento industrial, levando à necessidade de incorporação das camadas populares ao processo político.

\footnotetext{
${ }^{1}$ Embora não utilize neste texto a mesma expressão utilizada por Francisco Weffort ('classes populares'), creio que posso aplicar o mesmo significado que o autor lhe emprestou: "Pode-se, sem dúvida, falar de classes populares ou de massas populares, expressões imprecisas mas de qualquer modo úteis para captar a homogeneidade possível a esse grande conjunto de pessoas que ocupam os escalões sociais e econômicos inferiores nas diversas áreas do sistema capitalista vigente no Brasil.” (Weffort, 1989, p.72)
} 
Assim, esses dois eventos fornecem as condições iniciais para um processo de democratização do Estado, em que as oligarquias rurais vão sendo paulatinamente deslocadas do poder político e as camadas médias urbanas, os setores ligados à industrialização e, particularmente, as camadas populares vão-se constituindo em variáveis importantes na disputa política na qual se equilibra o Estado.

Em face do escasso peso político que os grupos participantes do poder detinham no momento da revolução, não conseguindo fazer com que seus interesses pudessem ser alçados à condição de interesses de toda a nação, nenhum deles, por si só, pôde oferecer as bases de legitimidade do Estado brasileiro que se formava. Desse modo, a concepção de um Estado que não defendia os interesses de quaisquer dos grupos à exclusão dos demais, e se impunha, soberano, ao conjunto da sociedade, pôde efetivar-se, mas, por isso mesmo, não pôde deixar de arregimentar as únicas forças sociais que lhe dariam sustentação: as camadas populares.

É nessa condição que as camadas populares são reconhecidas - pela primeira vez - como um novo ator político. Na configuração que tomam no cenário nacional, no período que se estende de 1930 a 1964, a relação entre o Estado, através de seu líder, e as massas populares condiciona as potencialidades e os limites de sua participação, no âmbito do que a tradição histórica brasileira chamou de populismo.

Fomentando a exaltação do poder público representado pelo Estado, cujo líder mantinha relação direta com os indivíduos reunidos na massa, o populismo brasileiro reforçava a personalização do poder, eliminando as mediações políticas e sociais para que este se exercesse, mas nesse mesmo movimento era forçado a reconhecer as camadas populares 
como um novo parceiro político cujas reivindicações eram legítimas. Foi Weffort quem definiu:

"O populismo foi um modo determinado e concreto de manipulação das classes populares mas foi também um modo de expressão de suas insatisfações. Foi, ao mesmo tempo, uma forma de estruturação do poder para os grupos dominantes e a principal forma de expressão política da emergência popular no processo de desenvolvimento industrial e urbano. Foi um dos mecanismos através dos quais os grupos dominantes exerciam seu domínio mas foi também uma das maneiras através das quais esse domínio se encontrava potencialmente ameaçado." (Weffort, 1989, p.62-63)

Em meados da década de 60, a intensificação das crises econômicas, o aumento do custo de vida, as sucessivas greves de trabalhadores em todo o país, a organização dos trabalhadores do campo em ligas camponesas e em sindicatos rurais, e a exacerbação das posições nacionalistas assinalaram o agravamento dos problemas estruturais brasileiros e o esgotamento da manipulação populista. Todas as tentativas buscadas que procuraram manter aquele precário equilíbrio, e postergar a desintegração anunciada fracassaram, reduzindo as margens de compromisso entre os grupos que sustentavam o Estado e trazendo à luz um movimento popular de novo tipo. Quando, finalmente, Jango Goulart se decidiu pelas "reformas de base", ocasionou o colapso do regime populista.

O Golpe de 64, levado a cabo pelos militares, e que se autolegitimou sob o pretexto de restaurar a ordem e a paz social, de combater a corrupção e de retomar o crescimento econômico, acabou por provocar, com a determinação de expurgar o "populismo subversivo", a desmontagem daquela configuração que as camadas populares haviam tomado no cenário público do período populista, sem, contudo, conseguir anular completamente a presença popular na vida pública do país. 
O que se consumou com o Golpe militar foi uma aliança estratégica entre militares radicais e tecnoburocratas na qual ambos se legitimavam: os militares apoiando-se nos tecnocratas para fazer a economia funcionar e estes, por sua vez, apoiando-se nos militares para permanecer no poder. Desse modo, a tecnocracia militar consolidava o poder ditatorial à medida que o Executivo tinha êxito em sua política econômica. Como decorrência, no campo jurídico-político observou-se a suspensão dos direitos políticos e cassações de mandatos parlamentares, a extinção dos partidos com a eleição indireta para presidente da República, a intervenção nos sindicatos, o fechamento das entidades estudantis, o expurgo de professores, pesquisadores e estudantes das instituições de ensino e pesquisa, o recesso parlamentar e a concessão de poderes quase totais e absolutos ao Governo.

É nesse contexto, marcado por práticas de poder regidas por uma lógica que se orientava pela "despolitização", pela disciplinarização e pela privatização da vida social, que emergem os chamados movimentos sociais urbanos nos anos 70 e $80^{2}$, assinalando uma nova configuração das camadas populares na cena política do país ${ }^{3}$.

Essas novas formas de participação social e política das camadas populares surgiram a partir da não-aceitação das condições de vida geradas no processo de formação dos grandes centros urbanos do país, no âmbito das chamadas contradições urbanas. As grandes cidades, ao reunirem a mão-de-obra potencial e efetiva para as promissoras

\footnotetext{
2 Embora não desconheça a rubrica de "novos" movimentos sociais, mais abrangente, aplicada a mobilizações surgidas também a partir da década de 70, tais como os movimentos de mulheres, os movimentos ecologistas, os movimentos pacifistas, restrinjo-me, aqui, às mobilizações que congregaram as camadas populares, atingidas por problemas agudos de sobrevivência nas periferias das grandes cidades.

${ }^{3} \mathrm{O}$ que se segue são as características mais gerais dos movimentos sociais urbanos, ainda que os diferentes trabalhos sobre o tema tragam enfoques e destaques distintos e que, a partir da década de 80 , se observe uma inflexão na análise dos movimentos, marcada pela institucionalização da relação deles com as agências públicas.
} 
indústrias, ao mesmo tempo em que concorreram para o desenvolvimento do sistema capitalista de produção criaram necessidades a serem atendidas para que a força de trabalho pudesse se reproduzir. No entanto, o poder público orientou a sua ação para investimentos na infra-estrutura urbana que alimentaria a expansão industrial, em detrimento dos investimentos em serviços e equipamentos de consumo coletivo (água, luz, esgoto sanitário, asfalto, transporte, saúde, educação, etc.), imprescindíveis para a sobrevivência da população, e, conseqüentemente, para a reprodução da força de trabalho. Não priorizando arcar com os custos de reprodução da força de trabalho, a ação do poder público acabou por reforçar as precárias condições de vida dos trabalhadores, uma vez que as periferias urbanas eram áreas de moradia mais distantes dos locais de trabalho, para as quais os trabalhadores haviam-se deslocado após sua progressiva expulsão das áreas mais centrais, valorizadas pelo capital.

Portanto, foram as carências urbanas os móveis marcantes das mobilizações e das reivindicações realizadas pelos moradores das periferias em prol da melhoria de suas condições de vida.

Ao experimentarem um sentimento de desamparo diante da sociedade mais ampla, as camadas populares desenvolveram entre seus membros laços de solidariedade na luta pela sobrevivência diária: foram relações de vizinhança, de compadrio e de amizade que acabaram por dar origem às associações comunitárias, aos Clubes de Mães ${ }^{4}$, ao Movimento do Custo de Vida, contando nesse processo com as Comunidades Eclesiais

\footnotetext{
${ }^{4}$ Embora desde fins dos anos 50 já existissem clubes de mães e formas similares de organização de donas de casa, patrocinadas pela Prefeitura e por associações beneficentes, que tinham uma feição eminentemente assistencialista, a mudança de seu caráter, no início da década de 70, deve ser creditada à ação institucional da Igreja Católica - através da atuação dos agentes pastorais - que passou a valorizar a auto-organização e a luta contra a injustiça em detrimento do assistencialismo caritativo. (Sader, 1995)
} 
de Base (CEBs), organizações voluntárias essencialmente leigas apoiadas pela Igreja Católica.

Ratificando essas novas formas de sociabilidade, as CEBs consolidaram uma maneira de elaborar ações coletivas, ao evitar a institucionalização da representação e incentivar a participação permanente de todos, tanto na tomada de decisões quanto na execução das ações. Na discussão e na busca de soluções, à luz da doutrina cristã, para os problemas cotidianos que afligiam os moradores das periferias das metrópoles, as Comunidades Eclesiais de Base contribuíram para que as camadas populares pudessem direcionar a pressão coletiva para o Estado, identificado como o provedor da sociedade como um todo e como seu antagonista político.

O que importa destacar aqui são os significados que os movimentos sociais urbanos concretizaram no momento em que surgiram: embora tão localizados em suas reivindicações, esses movimentos se projetaram para além de seu âmbito ao assumirem um caráter simbólico na experiência compartilhada das várias faces da opressão vivida naqueles anos e na descoberta da ação coletiva como abertura de um espaço público sistematicamente negado pelo Estado.

Marcando uma ruptura com a história passada, os movimentos sociais urbanos redefiniram ambos os espaços, público e privado. Em sua configuração anterior, no âmbito do populismo, as camadas populares haviam sido incorporadas por um Estado que as havia utilizado, fazendo uso da noção de dádiva, para se equilibrar com os grupos no poder, e que, nessa condição, tinha galvanizado a esfera pública; em sua nova configuração, nas décadas de 70 e 80, no âmbito dos movimentos sociais urbanos, as 
camadas populares refundavam a esfera pública por meio da desestruturação dos espaços tradicionais da política (partidos e sindicatos), ao trazer para a vida coletiva as experiências individuais e fragmentadas da vida privada.

Recusando condições de vida experimentadas como situações de privação, de injustiça, de exploração e de opressão, as camadas populares elaboraram a noção de direitos e se fizeram reconhecer como sujeitos políticos nas lutas por suas reivindicações. Nas palavras de Vera Telles:

\begin{abstract}
"Os indicadores da novidade que os movimentos dos moradores de periferia pareciam revelar eram dados por práticas reivindicatórias que escapavam dos esquemas tradicionais do clientelismo político: por práticas associativas em que parecia ausente a ação diretiva e hegemônica de grupos organizados de esquerda; por formas de organização articuladas a partir de interesses imediatos referentes às condições de vida $\mathrm{e}$ moradia e desvinculadas de instituições do Estado e partidos oficiais." (Telles, 1987, p.56)
\end{abstract}

Desse modo, são as dimensões da vida cotidiana - o trabalho, a moradia, a educação, a saúde, os transportes, a luz, a água, etc. - que transformam a esfera privada em uma questão política e de politização, redefinindo o espaço público e permitindo às camadas populares recuperarem o significado da ação coletiva.

Nesse sentido, a luta por direitos empreendida pelas camadas populares recolocará o conflito no centro da vida social, obrigando o Estado a reconhecer como políticas ações que não se encontram institucionalizadas como relações de poder articuladas por ele.

Como bem observou Vera Telles:

"Foi sobretudo através das práticas desses movimentos, na nova visibilidade adquirida por eles, que pudemos repensar a noção de política. Não como algo que se reduz às relações de poder instituídas a nível do Estado, mas como práticas instituintes que criam e recriam os espaços para o seu exercício.” (Telles, 1984, p.29, grifos no original) 
Foram, portanto, essas práticas instituintes que, refundando a esfera pública pela sua ampliação, construíram os consensos éticos fundamentais para a ruptura com o estado de solidão e de isolamento que perpassava as lutas e as experiências de participação comunitárias e criaram novos espaços de reconhecimento popular, elaboraram inéditas identidades coletivas e afirmaram direitos.

No entanto, se essas práticas instituintes inauguraram uma nova noção de política, ao criarem os espaços para o seu exercício, elas mesmas, para serem reconhecidas, provocaram e demandaram a interlocução do Estado. No diálogo com o Estado, muitas vezes, a consecução das metas imediatas relativas ao objeto das lutas representou o fim da mobilização, uma vez que o Estado, sendo simultaneamente o alvo e o unificador dos movimentos sociais, fixava os limites dentro dos quais as ações reivindicativas se esgotavam. (Jacobi, 1987)

Em decorrência, por compartilharem o mesmo sistema de referimento, por se estabelecerem no mesmo campo simbólico, por se legitimarem como pólos de uma mesma relação, as camadas populares e o Estado se vincularam em um processo de mão dupla, no qual aquelas criaram as condições para interferir na dinâmica de funcionamento do Estado, e em que este, pressionado, teve de responder de alguma maneira às reivindicações para manter sob controle a situação.

Mas se foi dentro desse quadro, em que o resultado do conflito entre o movimento social e o sistema institucional foi uma síntese que transformou ambos (Silva e Ribeiro, 1985), e em que, portanto, os limites dos movimentos se apresentaram como estruturais 
por fazerem parte do próprio processo político, esses limites não se restringiram a esse processo, devendo-se, ainda, considerar os condicionantes conjunturais que determinaram a progressiva neutralização das mobilizações.

As mudanças políticas que ocorreram no país a partir dos primeiros anos da década de 80, que marcaram a redemocratização da sociedade brasileira, com o reaparecimento da atividade político-partidária, com a ascensão da oposição ao poder em diversos estados, e com a consequiente parcial incorporação das demandas das camadas populares, significaram para os movimentos sociais um dilema entre a continuidade da mobilização e sua institucionalização ${ }^{5}$.

Isto porque para as camadas populares, que haviam empreendido suas mobilizações em decorrência da precariedade ou da ausência de canais de representação, a presença e a atuação dos partidos significava a possibilidade de se obter eficácia política em suas demandas, uma vez que teriam acesso às estruturas estabelecidas. Por outro lado, essa aproximação com a representação política tradicional teve também o seu reverso: os próprios agentes das burocracias estatais e partidárias buscaram, em épocas de eleição, as lideranças dos movimentos para, por meio delas, expandirem sua influência, o que se traduziu, em muitos casos, no esfacelamento das comissões, no esvaziamento das associações comunitárias, em resumo, na desmobilização.

Para agravar esse quadro, mais recentemente, desde os anos 90, o modelo de desenvolvimento que se instaurou no país, na nova ordem político-econômica

\footnotetext{
${ }^{5}$ Vários estudiosos dos movimentos sociais apontaram, entre seus limites, a institucionalização de suas práticas: Cardoso (1984), Evers (1984), Silva e Ribeiro (1985), Cardoso (1987), Jacobi (1987), Telles (1987), Jacobi (1990), Cardoso (1994) e Gohn (1997).
} 
representada pela globalização, articula uma difícil conjuntura em que os movimentos dos trabalhadores vêem diminuído o seu poder de barganha, em face da redefinição do papel do setor informal do trabalho no processo produtivo; isto porque a pulverização da produção em uma infinidade de mercados, segundo a lógica do menor custo, acaba por desagregar os trabalhadores, modificando seus padrões de sociabilidade e consciência, num cenário em que o desemprego passa a ser considerado uma característica natural das sociedades competitivas.

O que se contabiliza, portanto, são evidências da deterioração das mobilizações coletivas, diante das dificuldades em articular as lutas das camadas populares e da descaracterização de seus organismos de representação.

Desse modo, no que diz respeito à participação política das camadas populares, se observa, por referência à ativa e visível participação nos movimentos sociais urbanos dos anos 70 e 80, uma relativa ausência de participação desde os anos 90. Contrapondose a um primeiro momento, em que a redescoberta de modos de participação nos movimentos sociais foi saudada pelos estudiosos como indício da capacidade de autoorganização e de auto-determinação das camadas populares em ruptura com uma participação, no âmbito do populismo, sob a tutela do governante, um segundo momento revela o desencanto e a desesperança que tomaram conta dos pesquisadores, em face da perda de dinamismo dos movimentos sociais.

No que se refere à participação das camadas populares na educação, registra-se, na literatura acadêmica da última década, uma ênfase maior nos estudos relativos à gestão do sistema de ensino através dos canais institucionais, em comparação com os estudos 
relativos à luta pelo acesso à educação e pela melhoria da qualidade do ensino ${ }^{6}$, sugerindo que os trabalhos acompanharam o movimento real em favor da intensificação da institucionalização dos movimentos.

Além disso, a notável expansão da matrícula no ensino fundamental regular e público nas duas últimas décadas ${ }^{7}$ também contribui para que se possa pensar que o significado dos movimentos se alterou, desvinculando-se da luta das camadas populares pelo acesso à educação na medida que vem sido atendida a demanda por mais vagas nas escolas.

Uma vez que as práticas instituintes que caracterizaram os movimentos sociais adquiriram uma marca de visibilidade - tornando públicas as experiências individuais da vida privada e subvertendo as esferas pública e privada - , e uma vez que se tem em conta uma possível crise que acomete as mobilizações coletivas, pode-se perguntar se isto se traduz em ausência de participação das camadas populares.

Esta pergunta também se aplica particularmente ao campo da educação, na medida que a luta pela democratização do acesso e a luta pela democratização da gestão tornaram visível a participação das camadas populares, ao viabilizarem uma participação homogênea e compacta, originada na convivência igualitária e de contestação dos movimentos sociais; em suma, uma participação comunitária.

\footnotetext{
${ }^{6}$ Levantamento por mim realizado das dissertações e teses no campo educacional que envolvem a participação das camadas populares mostra que, na última década, predominaram os estudos que tratam especificamente da democratização da gestão em relação aos estudos que tratam da democratização do acesso e da gestão: de 1991 a 1998, para cada três trabalhos que tratam da gestão do sistema de ensino através dos canais institucionais existe um que trata da luta pelo acesso à educação e pela melhoria da qualidade do ensino. Esse conjunto de trabalhos será analisado mais detidamente nos próximos dois capítulos.

${ }^{7}$ No período de 1975 a 1997 , a matrícula inicial total no ensino fundamental no país cresceu $75,1 \%$, correspondendo a um crescimento de "apenas" $45,3 \%$ na rede privada, comparativamente a um aumento da ordem de 179\% na rede pública. (Mansano, Oliveira e Camargo, 1999)
} 
A perspectiva que este trabalho apresenta é a de que o declínio de um padrão de engajamento coletivo não significa ausência de participação, pois práticas bastante ricas e bastante ativas de participação são observadas entre pais e mães de alunos das camadas populares. É Alberto Melucci quem fornece as pistas para compreender que a participação decorre das possibilidades que surgem nas relações que se estabelecem entre os atores sociais, não se mostrando homogênea e compacta - e, principalmente, visível - desde sempre. Para Melucci, a aparente unidade e homogeneidade com as quais os atores coletivos se apresentam na cena social "são sempre resultado de processos sociais que tornam possível, eventualmente, a formação de um sujeito coletivo" (Melucci, 1997a, p.13, meu grifo). Nesse sentido, um sujeito coletivo é uma conformação possível, mas não necessária, tendo em vista os inúmeros arranjos que se tem de realizar para que as diferentes orientações da ação, para que as diversas estruturas de relações possam se configurar como uma unidade. Proponho, então, que se considere as perspectivas do ator social para que se perceba outras formas de participação - que chamo, na falta de termo mais adequado, de participação fragmentada.

Para que se possa compreender a importância dessas outras formas de participação, o Capítulo 1 buscará mostrar que a participação é caracterizada por um conjunto de circunstâncias que se sucedem e que lhe dão a marca de um processo, enquanto o Capítulo 2 buscará indicar que aquelas circunstâncias, em decorrência de serem circunstâncias diversificadas, não se aplicam à idéia de um coletivo, à idéia de comunidade. 
Assim, o Capítulo 1 irá situar a participação dos pais e mães das camadas populares no contexto das análises que se fazem dos movimentos sociais relacionados à educação no Brasil e no âmbito da elaboração teórica que se realiza dos movimentos, com o propósito de evidenciar o caráter processual da participação.

O Capítulo 2 irá apontar a vinculação do conceito de comunidade com a ação coletiva e sua re-significação no contexto das determinações do poder político e da institucionalização dos movimentos sociais, com o propósito de dissipar a aparente homogeneidade do conceito, e abrir a possibilidade de se pensar outras formas de participação.

Finalmente, o Capítulo 3 - um estudo de caso - procurará mostrar aspectos diferenciados e heterogêneos da participação de pais e mães das camadas populares que revelam o caráter fragmentado da participação. 


\section{Capítulo 1}

\section{A participação dos paise mães, a luta por direitose os movimentos sociais}

\section{A particípação dos pais e mães e a luta por direitos}

A luta dos pais e das mães das camadas populares pela educação pública tem, no Brasil, uma longa e acidentada história, cujos primeiros registros coincidem com a intensificação do processo de urbanização, que ocorre principalmente na cidade de São Paulo, transformada no centro dinâmico do sistema capitalista do país em meados do século passado.

A deterioração das formas de produção no campo e o concomitante processo de industrialização, acelerando a urbanização dos precários núcleos de povoamento, acabam por provocar alteração na demanda social de educação, uma vez que as camadas médias e populares passam a exercer pressão constante sobre o sistema escolar para que este se expanda. Para que se tenha uma idéia do volume dessa demanda, entre 1920 e 1970, observou-se um aumento da matrícula escolar mais acentuado do que o próprio crescimento populacional, considerando-se a faixa etária de 5 a 19 anos em todo o país $\left(\right.$ Romanelli, 1989) ${ }^{8}$.

Todavia, em que pesem os esforços dos estratos médios e populares pelo acesso à educação, é no interior do próprio sistema educacional que suas aspirações serão

\footnotetext{
${ }^{8}$ Enquanto o índice de crescimento demográfico passou de 100, em 1920, para 276, em 1970, o índice de crescimento da matrícula escolar passou de 100 a 1653, no mesmo período. Tendo-se em conta que as elites brasileiras esforçaram-se por conter a pressão das camadas populares, concedendo-lhes parcimoniosamente unidades escolares, e que mesmo o crescimento da matrícula não significou pleno atendimento à população em idade escolar, pode-se avaliar - por aquela desproporção - o notável empenho dos estratos médios e populares na luta pela escola.
} 
frustradas. Para isso, concorreram a seletividade do sistema, que teve na repetência, na evasão e em uma educação livresca seus mecanismos legitimadores, e a expansão de um tipo de ensino - ensino secundário - que já não correspondia às novas necessidades criadas com a expansão econômica. Os dois arranjos, ao reforçarem as deficiências quantitativas e estruturais da expansão do ensino, não só não arrefeceram a pressão da demanda como ainda lhe deram continuidade. Nesse contexto, a orientação da demanda foi para que se aumentassem as vagas não apenas no ensino primário, mas, no que se refere ao ensino médio, também no seu ramo secundário, que conferia status e dava aos estratos médios e populares a possibilidade (ao menos imaginária) de ascensão social.

Um registro bastante significativo, e pioneiro, da pressão popular na luta pelo direito à educação foi realizado por Celso Beisiegel (1964), que mostrou a utilização das aspirações populares pela educação feita pelo deputado estadual no processo de democratização do ensino secundário no estado de São Paulo. Revela-nos o pesquisador que, em meados do século passado, diante do atendimento cada vez mais crescente da clientela potencial do ensino primário, as reivindicações de oportunidades educacionais nas áreas urbanas direcionam-se para o ensino secundário, apesar de sua inadequação para a preparação dos novos quadros profissionais indispensáveis à sociedade urbana e industrial. Em face dessa necessidade real sentida pela população, o deputado estadual paulista é pressionado pelas reivindicações de criação e instalação de ginásios nas diferentes localidades do interior do estado, e se aproveita da flexibilidade e da definição imprecisa dos critérios elaborados para aprovação de projetos de criação de ginásio no âmbito do poder legislativo para criar, aproximadamente, um ginásio em cada município do estado de São Paulo entre os anos de 1940 e 1962. 
De modo similar, Marília Spósito (1984) estuda a expansão da rede de ginásios públicos no município de São Paulo, entre os anos de 1945 e 1958, mostrando as condições contraditórias em que esta ocorreu. Nesse caso, as contradições não apenas se manifestavam na ausência de recursos financeiros e materiais que dessem conta da referida expansão, mas ainda na coexistência de orientações conflitantes nos setores ligados à educação em São Paulo. A pesquisadora observa que os movimentos de bairros, na busca de maiores oportunidades educacionais, pressionavam o poder público, que apelou para o recurso da instalação de classes noturnas e de ginásios noturnos em prédios de grupos escolares e para o desdobramento dos ginásios oficiais em outros estabelecimentos - as chamadas secções. Na capital, a conquista de ginásio estadual por parte dos membros das Sociedades Amigos de Bairros acabava por estimular aspirações difusas das populações da periferia, que não dispunham de alternativas educacionais após o curso primário. Nesse sentido, os ganhos políticos na concessão de uma rede de ginásios mobilizaram o prefeito, e depois governador Jânio Quadros, que incentivava as reivindicações populares, em que pesem as tentativas de contenção de abertura de escolas secundárias originadas na Assembléia Legislativa e nos órgãos técnicos da Secretaria da Educação e a opinião desfavorável de setores influentes da imprensa.

Tanto Beisiegel quanto Spósito, ao estudarem a expansão dos ginásios oficiais no estado de São Paulo, mostram que a demanda popular pelo ensino secundário esteve condicionada pelas transformações sócio-econômicas por que passou o país depois de 1930, e que teve como conseqüência um enorme crescimento das cidades. Orientada pela instalação e proliferação dos estabelecimentos industriais, a população das zonas rurais se dirige para os núcleos de povoamento localizados próximos às indústrias na 
cidade de São Paulo, contribuindo para o processo de adensamento populacional dessas novas áreas. No entanto, o descompasso entre o desenvolvimento econômico da metrópole e uma infra-estrutura de serviços coletivos urbanos fez da região da Grande São Paulo um local de carências para a população que aí habitava.

\section{As contradições urbanas e os movimentos sociais}

Com a intensificação do processo de industrialização que tem início por volta de 1950 , começa-se a agravar o problema de moradia das classes trabalhadoras. Impedidas de habitar as áreas mais centrais da cidade, devido ao alto preço dos terrenos, as classes trabalhadoras se voltam para as áreas periféricas, ocupando lotes de terreno desprovidos de qualquer melhoramento urbano. Tendo o encargo de construir suas próprias casas, os ocupantes desses lotes das áreas periféricas ainda não podiam dispor dos equipamentos e dos serviços que deveriam acompanhar os núcleos de habitação, tais como: água, luz, esgoto, transporte, escola, posto de saúde, policiamento e asfaltamento das ruas.

Como parte do processo de consolidação do capitalismo brasileiro, a atuação do poder público deveria garantir as condições que estivessem em seu âmbito para que o capital se reproduzisse, e o fez ao priorizar os serviços destinados à expansão da produção em detrimento dos serviços destinados a atender as necessidades de sobrevivência da população, diante da limitação dos recursos públicos.

As contradições urbanas, assim, expressam uma desigualdade na aplicação do fundo público, decorrente da primazia dada pelo financiamento estatal à reprodução do capital. A formação da metrópole, embora fosse conveniente para o desenvolvimento do 
capitalismo - devido à concentração física dos meios de produção, da força de trabalho, do mercado consumidor e dos serviços correlatos à circulação das mercadorias - , acabava por determinar um modelo de urbanização que infligia às classes trabalhadoras 9 um conjunto de carências sociais e urbanas e que se constituíam em necessidades derivadas da própria sobrevivência dessas classes nas condições geradas pelo próprio capitalismo.

Pressionado pela população das áreas periféricas da cidade - a mais atingida pela ausência de equipamentos e serviços públicos - , que via desmascarada a ideologia da igualdade social, ao Estado nada mais restava do que se preparar para o confronto. Nas palavras de José Álvaro Moisés:

\begin{abstract}
"Portanto, era inevitável que as contradições geradas pelo desenvolvimento urbano lançassem as classes populares em uma relação antagônica com o Estado. Este tinha que desempenhar, simultaneamente, funções contraditórias entre si, tais como: assegurar as condições de vida para o conjunto da população e, ao mesmo tempo, assegurar o uso desenfreado do solo, baseado na propriedade privada; manter as condições para o funcionamento da cidade, como lócus de atividades produtivas e de reprodução da população sem contar, entretanto, com os recursos necessários e os meios suficientes para criar e manter os serviços e equipamentos coletivos de que necessitava essa população; manter o caráter impositivo da concentração espacial das atividades produtivas, decidido descentralizadamente e, de outra forma, assegurar o controle e a coesão da população que de outro lado começava a negar aquela lógica pelas suas reivindicações, e assim por diante.” (Moisés, 1978, p.420-421)
\end{abstract}

Como desdobramento das contradições do capitalismo que se manifestam nas condições de vida na cidade, os movimentos sociais urbanos surgem com força no cenário urbanoindustrial na década de 70, num momento em que uma normatividade tecnocrática e

\footnotetext{
9 A expressão 'classes trabalhadoras' utilizada aqui pretende enfatizar, por correlação, o caráter contraditório da reprodução do capital no processo de urbanização. No entanto, estou de acordo com José Álvaro Moisés, que alerta para o conjunto dos estratos sociais atingidos pelas contradições urbanas: "Essa problemática [gerada pela questão urbana] surgiu na forma indireta dos efeitos dessas contradições, que se expressam no cotidiano das populações locais em sua condição de moradores, sejam operários, comerciários ou funcionários públicos.” (Moisés, 1978, p.VI)
} 
repressora, buscando encobrir a existência dos conflitos na sociedade, parecia despolitizar e privatizar a vida social no país (Telles, 1987).

Com efeito, o Golpe de 64, levado a cabo pelos militares, efetivou uma série de medidas que, no campo jurídico-político, se caracterizaram pela implantação de uma ditadura, com a supressão dos procedimentos regulares democráticos, e que corresponderam, no campo econômico, à concentração de poderes nas mãos de uma tecnoburocracia, decidida a reformar e modernizar as instituições econômicas. Assim, as medidas destinadas ao combate à inflação, à recuperação da confiança dos credores internacionais e à retomada do desenvolvimento, que se conjugavam às reformas destinadas ao reordenamento bancário, fiscal e administrativo - cujo objetivo era capacitar o Estado para intervir na economia - , puderam ser implementadas sem a impertinência de um Legislativo esvaziado de suas funções e tiveram, ante a sociedade mais abrangente, a garantia da força de um regime equipado com os instrumentos de exceção.

É nesse contexto que reaparecem as classes populares no cenário público, reestruturando os espaços tradicionais de se fazer política. Sob o aspecto sócio-político, os movimentos sociais urbanos surgem no Brasil, constituindo-se tanto de forma fragmentária quanto ao desamparo das forças externas (Brant, 1981). De forma fragmentária porque, segundo Vinícius Caldeira Brant (1981), em face da repressão à manifestação política dos interesses populares, com o bloqueio dos canais tradicionais de representação (partidos e sindicatos, por exemplo), a organização daqueles interesses tomou uma feição defensiva, diretamente relacionada com a sobrevivência diária (basicamente, demandas por equipamentos sociais urbanos, como água, luz, transporte, 
escola, etc.), beneficiando-se dos laços primários de solidariedade das relações de vizinhança, parentesco, compadrio ou amizade. Em contrapartida, ainda segundo Brant, a identidade dos movimentos foi preservada da influência das forças externas devido ao fato de o único partido legal de oposição no país na época não ter sido capaz de estabelecer vínculos de representação real com os movimentos populares e ainda pelo fato de os estudantes terem encontrado forte resistência à sua participação por parte das lideranças dos movimentos, temerosas de perder o controle de suas bases.

Sob o aspecto sócio-econômico, a emergência dos movimentos sociais urbanos no Brasil esteve condicionada à crise econômica dos anos 70, que forçou os movimentos a desenvolverem ao máximo seus recursos (e "reflexos") defensivos contra o Estado, levando-os a cuidar da própria sobrevivência (Weffort, 1996), em um contexto em que as ideologias - fossem elas concepções alternativas da economia, da sociedade ou do Estado - não eram acolhidas no meio social mais amplo.

\section{Movimentos sociais no Brasil: as díficuldades dos pesquisadores}

No Brasil dos anos 70 e 80 inúmeras foram as mobilizações populares que confrontaram o poder público, representante de um Estado comprometido com as condições gerais de reprodução do capital. Pela sua importância e pelo seu significado, era natural que os movimentos sociais se tornassem objeto de estudo de muitos pesquisadores que ofereceram interpretações diversas ao fenômeno. 
Sem pretender traçar um panorama completo e exaustivo das perspectivas em que o tema dos movimentos sociais foi tratado pelos pesquisadores, algumas abordagens se revelaram importantes pelo fato de provocarem um estimulante debate sobre a matéria, indicando, por essa via, a complexidade do fenômeno.

Por exemplo, em relação à centralidade do poder político na análise dos movimentos sociais do país, alguns estudiosos, ao lhe dar menor ênfase, apontaram os limites quanto ao alcance das reivindicações, enquanto outros, ao lhe conceder maior peso, destacaram as potencialidades das demandas dos movimentos.

A esse respeito, Eunice Durham (1984) considerava que a dinâmica interna dos movimentos colocava problemas para a atuação conjunta ampliada. Isto porque, segundo ela, a instituição de uma nova prática coletiva, em que a consulta direta e permanente dos participantes se torna procedimento rotineiro, limita seu acontecimento em pequenos grupos, uma vez que só nesses reduzidos agrupamentos é que se pode utilizar plenamente esse ritual. Além disso, Durham considerava também que o fato de as decisões serem tomadas invariavelmente por consenso favorecia cisões, multiplicando os grupos ao invés de ampliá-los. Em outras palavras: para ela, um dos limites impostos aos movimentos sociais dizia respeito à experiência da igualdade, que, quando restrita à prática da democracia direta, impede o exercício da democracia representativa pelos óbices que se interpõem à institucionalização de mecanismos de representação.

Em outra perspectiva, mas ainda no campo dos limites dos movimentos sociais, Pedro Jacobi (1987) observava que, no plano da realidade dos movimentos, havia uma 
dificuldade em regularizar as relações com o Estado por meio da negociação, o que comprometia seus próprios objetivos. De acordo com ele, essa dificuldade real correspondia, no plano das análises dos movimentos, a uma tendência à sobrevalorização do caráter espontâneo da mobilização.

A especificidade das demandas é outro limite que pesquisadores constatavam nos movimentos sociais urbanos. Segundo Vinícius Caldeira Brant (1981), era essa especificidade que permitia perceber a complexidade da relação Estado-movimentos e compreender até onde se estendia o âmbito de suas práticas. Ruth Cardoso (1984) assinalava nessa relação uma via de mão dupla: se, por um lado, o Estado, pressionado pelas mobilizações, tinha de dar uma resposta - e o fazia "de maneiras variadas, segundo a época, a conveniência política e o tipo de reivindicação" (p.228), evidenciando o amplo campo de manobra que possuía, que lhe possibilitava absorver efetivamente algumas demandas populares - , por outro, era o Estado que acabava criando expectativas de demanda e funcionando como um indutor de reivindicações ao formular projetos sociais específicos para certas áreas (especialmente as que eram consideradas politicamente prioritárias) e criar mecanismos para sua implementação. Desse modo, tanto num caso quanto no outro, o caráter específico e local das questões estava a indicar que as ações reivindicativas tinham limites bastante definidos, que se dirigiam ao Estado e se resolviam no próprio Estado.

Se, para alguns pesquisadores, os movimentos sociais urbanos podiam se ressentir, internamente, da dificuldade em institucionalizar mecanismos de representação, e, externamente, da dificuldade em regularizar as relações com o Estado por meio da 
negociação, para outros estudiosos, a absorção dos movimentos pela política tradicional também revelava, pelo reverso, a outra face de seus limites.

Quanto a esse aspecto, Tilman Evers (1984) criticava, nos estudos sobre os movimentos sociais, a constatação do progresso do movimento sob uma trajetória invariável, que partia de um estágio de manifestação cultural ainda pura, seguia pelas suas articulações sociais e chegava até a sua atuação política. Não desprezando a possibilidade de, nesse processo, haver um crescimento da consciência política, o pesquisador lembrava que outras formas e conteúdos de consciência social não eram valorizados nesse tipo de análise, tais como os laços de cooperação e solidariedade que recriavam sujeitos por meio de "fragmentos de uma vida social significativa". Em contraposição àquela visão evolucionista de percurso, para ele, toda essa construção fragmentária de uma vida expressiva individual e coletiva podia perder-se no momento em que o movimento ganhasse consciência política ao indicar seus líderes para candidatos pelos partidos estabelecidos.

Também para José de Souza Martins (1989), a crise maior que atingia em cheio as classes subalternas e comprometia suas possibilidades políticas advinha do "intelectual orgânico do partido, presente nos grupos populares", que se constituía no "principal fator de esvaziamento das lutas populares em favor das organizações, dos partidos e da centralidade política do Estado." (Martins, 1989, p.135) Fazendo referência particular aos partidos políticos de esquerda, Martins afirmava que estes pressupunham a insuficiência política dos movimentos sociais ao desencadearem uma ação aparelhista sobre os mesmos, esquecendo-se de que as lutas sociais eram o grande passo político no Brasil dos anos 70 e 80. 
Contrastando com o destaque dado às limitações dos movimentos sociais urbanos, vários analistas ressaltaram a contribuição que estes trouxeram ao processo de democratização da sociedade, valorizando, nos movimentos, suas potencialidades .

Ilse Scherer-Warren (1987), por exemplo, assinalava, nos movimentos sociais surgidos no Brasil dos anos 70 e 80 , uma reação às formas autoritárias e de repressão política, às formas centralizadoras do poder e, também, uma reação ao caráter excludente do modelo econômico adotado no país naquela época. Segundo ela, essa reação se expressava por meio da elaboração de uma "cultura crítica", que possibilitava a criação de formas comunitárias de participação direta das bases e a autonomia frente ao Estado e aos partidos, marcando uma ruptura com os esquemas populistas do passado.

Já Tilman Evers (1984) argumentava que o elemento "novo" dos chamados "novos movimentos sociais" residia no seu potencial de modificar os padrões sócio-culturais e sócio-psíquicos do cotidiano, revertendo uma estrutura de dominação que operava pela realização de incontáveis atos cotidianos de obediência irrefletida à ordem existente. Para ele, as estruturas não burocráticas e as formas coletivas de tomadas de decisões nos movimentos sociais inauguravam uma capacidade nova para criar e experimentar modos diferentes de relações sociais cotidianas, "podendo revelar-se como mais político do que a ação imediatamente orientada na direção das estruturas de poder existentes." (Evers, 1984, p.15)

Eunice Durham (1984) relacionava o aspecto democrático dos movimentos sociais à ênfase na igualdade na constituição da coletividade. Seja no modelo de organização 
formal, que exigia mecanismos de representação, seja no modelo de organização comunitário, que evitava a institucionalização da representação e exigia uma atuação permanente de todos, era a igualdade efetiva dos participantes do movimento que sustentava as reivindicações coletivas.

Se quanto ao âmbito das práticas dos movimentos sociais havia significativa concordância dos analistas em relação à sua extensão em benefício da democratização da sociedade, não se observava o mesmo quando se tratava de avaliar se os movimentos sociais contribuíam ou não para a democratização do Estado.

A esse respeito, Ruth Cardoso (1984), de posse dos dados apresentados na literatura sociológica, chegava à conclusão de que o efeito das pressões populares sobre o aparelho estatal em seu conjunto não era tão determinante na formulação de políticas públicas com finalidades sociais e que, portanto, tanto sua formulação quanto o controle das aplicações acabavam por escapar totalmente à esfera de ação dos movimentos sociais.

No mesmo sentido, Pedro Jacobi (1987) observava que os atores políticos singulares dos movimentos sociais urbanos pouca influência exerciam na mudança efetiva dos objetivos da política governamental, embora se considerasse seu estilo de atuação alternativa aos padrões institucionais existentes, acrescentando que, na maioria dos trabalhos sobre os movimentos sociais, privilegiava-se mais o que o Estado cedia do que efetivamente controlava. 
Em grande parte dos estudos sobre os movimentos sociais urbanos, a condição do Estado relativamente aos movimentos estava a indicar que o confronto se fazia com um inimigo. Luís Machado da Silva e Ana Clara Ribeiro (1985) destacavam dois pontos que adquiriam estatuto de pressuposto no paradigma consolidado dos movimentos sociais no Brasil: o Estado como inimigo e o impacto transformador das mobilizações populares, o que, segundo eles, impedia de apreender na burocracia pública suas características históricas e conjunturais, que a tornava capaz de transformar-se em confronto com as reivindicações.

Indo na mesma direção de Silva e Ribeiro, Pedro Jacobi (1990) não reconhecia a polarização como um conflito entre, de um lado, o movimento social - espaço de liberdade - e, de outro, o sistema institucional - lócus de controle e dominação dos grupos reivindicantes. Recusando-se a trabalhar com hipóteses unilaterais de fenômenos apreensíveis enquanto relações (Jacobi, 1987), o pesquisador compreendia o processo como uma síntese que transformava a ambos - movimentos e Estado - concebendo este último ainda na condição de interlocutor.

De modo análogo, Ruth Cardoso (1984) aludia ao Estado perante os movimentos sociais, como “inimigo e legitimador" (Cardoso, 1984, p.224), e Eunice Durham assinalava que se, no confronto, o Estado era legitimado, também no confronto legitimava-se o próprio movimento, "nessa relação especular aparentemente essencial a um processo no qual o que parece estar em jogo é uma nova forma de cidadania." (Durham, 1984, p.29) 
Diante do cenário de reflexão agitado, polêmico e, por vezes, contraditório que se criou em torno dos movimentos sociais urbanos, pode-se creditar à sua indubitável importância política as dificuldades encontradas para a interpretação do fenômeno, que, deve-se ressaltar, não se restringem às mencionadas aqui.

Uma das dificuldades mais significativas reside nas condições estruturais em que os movimentos emergem no Brasil, que se expressam nas distorções do modo de acumulação capitalista instalado em um país de economia periférica, determinando a precariedade das condições de reprodução da força de trabalho por meio do consumo coletivo de equipamentos e serviços urbanos, e que certamente contribuíram para a vinculação dos movimentos sociais com uma certa situação de classe.

De modo análogo, o contexto sócio-histórico do surgimento dos movimentos, exercendo influência sobre sua dinâmica, permitiu que se ampliasse o âmbito das práticas dos movimentos sociais, imputando-lhes uma importância estratégica nas transformações da sociedade e do próprio Estado capitalista.

Deixando em segundo plano ajuizar o mérito ou o demérito das interpretações dos movimentos sociais urbanos no Brasil, trata-se, antes, de compreender que essas interpretações correspondem a um determinado momento histórico, e que, portanto, são tributárias do contexto político e ideológico da época em que foram produzidas.

No que se refere, particularmente, aos movimentos sociais relacionados à educação, a análise da participação dos pais e mães de alunos das camadas populares, em linhas 
gerais, também seguiu a orientação dada no período, embora se registrem trabalhos que exploram aspectos da participação pouco convencionais ${ }^{10}$.

\section{A luta por direitos: movimentos sociais no Brasit e a educação}

No campo da educação, numerosos estudos ressaltaram o papel desempenhado pela população organizada na obtenção, na manutenção e no funcionamento das escolas públicas frente a um Estado que tenta gerenciar as contradições entre as necessidades criadas pelo sistema econômico que ajuda a conservar. Essas contradições, como vimos, que se manifestam em uma demanda crescente por serviços coletivos e por equipamentos urbanos e uma capacidade limitada de destinar recursos para o financiamento desses serviços e equipamentos, põem a nu a desigualdade no acesso ao ensino público como um dos aspectos de um modo de inserção na sociedade e no espaço urbano que faz parte de um conjunto muito amplo de carências a que estão submetidas as camadas populares.

Os estudos sobre os movimentos sociais urbanos que tratam especificamente das demandas no campo da educação, embora incluam essas demandas no contexto mais geral das necessidades de sobrevivência das camadas mais empobrecidas da população nas cidades, certamente não deixam de considerar a condição particular de pais e de mães que lutam pela educação de seus filhos.

\footnotetext{
${ }^{10}$ A compreensão do caráter histórico das interpretações dos movimentos sociais na educação é destacada, mais recentemente, por Nilton Bueno Fischer (2000), que, em face das modificações ocorridas nas últimas décadas no cenário político brasileiro, constata a superação das formas clássicas de análise por parte das ciências sociais e humanas.
} 
Desse modo, com o objetivo de verificar como a literatura sobre a participação de pais e mães de alunos das camadas populares registrou os modos em que se deu essa participação, e, mais ainda, como essa literatura analisou o processo da participação, considerei que deveria examinar trabalhos acadêmicos publicados - dissertações e teses - que dissessem respeito às mobilizações das camadas populares pela educação no Brasil.

Para essa tarefa procurei estabelecer fontes de referência que pudessem fornecer critérios para uma necessária seleção do material. Julguei adequadas, então, por sua atualidade, por sua abrangência e pelo caráter sistematizado das informações, duas fontes de referência: a base de dados organizada pela Associação Nacional de PósGraduação e Pesquisa em Educação (ANPEd) e sistematizada pela organização nãogovernamental Ação Educativa, e o levantamento bibliográfico realizado por Elie Ghanem Jr. sobre a participação popular na gestão escolar, editado, sob a forma de livro, também pela Ação Educativa (Ghanem Jr., 1995). Orientei-me, ainda, subsidiariamente, pelo artigo de Maria Malta Campos (1991), "As lutas sociais e a educação", que procede a uma revisão da literatura sobre os movimentos sociais urbanos por educação.

Levando em conta que a produção acadêmica nacional sobre a participação de pais e mães das camadas populares se encaminha, não apenas para o estudo das demandas pelo acesso à escola e pela melhoria do ensino, mas também para o estudo da gestão da educação, realizei um recorte para poder dar conta, na análise, dos aspectos particulares da participação de pais e mães no processo de democratização do acesso, e assim os 
destacar dos aspectos particulares da participação de pais e mães de alunos no processo de democratização da gestão.

Neste momento, então, trata-se de tomar para exame trabalhos que fazem referência à luta dos pais e mães das camadas populares pelo acesso à escola e pela melhoria do ensino no contexto dos movimentos sociais urbanos, isto é, trabalhos que tratam prioritariamente da luta pelo acesso à educação mas que também podem abordar dimensões da luta pela democratização da gestão. Em momento posterior (Capítulo 2), análise similar será realizada sobre trabalhos que se ocupam especificamente da participação dos pais e mães das camadas populares na gestão da educação pela via dos canais institucionais.

Em trabalho inovador sob muitos aspectos, Maria Malta Campos (1982) registrou a luta por educação elementar em dois bairros da cidade de São Paulo empreendida por dois grupos de mulheres, em que a opção metodológica pela pesquisa participante permitiu que "as formas individuais e coletivas pelas quais se manifesta o conflito entre a população e a escola [fossem] recuperadas e analisadas em conjunto" com o grupo de pesquisadoras (p.141). No confronto pôde-se evidenciar os mecanismos sutis utilizados pela escola tanto para selecionar e excluir os alunos do processo de escolarização quanto para obstar as tentativas de participação das mães na gestão da unidade escolar. O trabalho registrou, ainda, os embates que as mulheres realizaram com as autoridades governamentais - municipais e estaduais - em favor da educação de seus filhos, reivindicando, para um dos bairros, o ensino de segundo grau, e, para outro, as quatro últimas séries do primeiro grau. Toda essa luta chamou a atenção da autora para a promissora contrapartida dessa complexa e difícil interação da população com as 
autoridades responsáveis pelo ensino público: o aprendizado de luta e a elaboração de uma consciência crítica.

A luta por creches na cidade de São Paulo enquanto expressão de movimentos reivindicatórios engendrados pela problemática dos meios coletivos de consumo foi objeto de estudo de Maria da Glória Gohn (1985), que reconstituiu sua articulação inicial, de 1973 a 1979; seu confronto com o Estado, em fins da década de 70; e sua "captura" pelo mesmo Estado, a partir dos primeiros anos da década de 80. Surgindo a partir das Comunidades Eclesiais de Base, dos Clubes de Mães, do Movimento da Carestia, do Movimento da Anistia e dos movimentos feministas, o Movimento por Creches em São Paulo se articulou para interferir, primeiramente, na distribuição das unidades pelos bairros, e, posteriormente, na própria construção das unidades e no processo de recrutamento dos funcionários. Com a sucessão dos embates, a administração municipal utilizou-se das rotinas burocráticas para descaracterizar a dimensão política da luta, especificar os problemas e os remeter à tramitação no tempo, conseguindo, dessa forma, esvaziar a pressão social dos movimentos. Como uma conclusão mais geral do estudo, Gohn constata que os movimentos populares urbanos não têm existência independente - constituindo-se em relação ao Estado, à Igreja, ou a outra entidade da sociedade civil - , e que não têm trajetórias lineares de desenvolvimento, dependendo dos projetos políticos que suas práticas cotidianas delineiam.

Em continuidade à investigação do importante papel que os movimentos de bairro na busca de maiores oportunidades educacionais exerceram na expansão da rede de ginásios públicos no município de São Paulo entre os anos de 1945 a 1958 (Spósito, 
1984; tratado no item 1 deste capítulo), Marília Spósito (1993) analisou, em sua tese de doutoramento, as lutas populares por educação no mesmo município entre os anos de 1970 e 1985. Interessando-se, ainda, em estudar os mecanismos de interação que o sistema de ensino público vinha propondo aos seus usuários no âmbito da unidade escolar naqueles anos, Spósito mostra que as concepções de integração escola/usuários eram marcadas por uma forte despolitização das relações, transformadas em relações entre grupos privados, em que a chamada "comunidade" era instada a cooperar com a escola, de forma material e humana. Complementando o trabalho, o acompanhamento dos movimentos por educação originários da zona leste da cidade de São Paulo, surgidos no final da década de 70 , que aglutinaram grupos de mulheres de Clube de Mães e membros de Comunidades Eclesiais de Base, permitiu à pesquisadora desvendar as relações sociais que entreteciam, no cotidiano, a luta por educação.

A classe trabalhadora esteve no foco do estudo de Maria Stella Ribeiro (1986), que analisou o significado da luta pela escola, a partir da representação que os moradores do bairro Paulo VI, de Belo Horizonte/MG, faziam daquela instituição. Na condição de bairro da periferia, as lutas sociais aí localizadas vinham responder às necessidades de consumo coletivo de seus moradores, dentre as quais a luta pela escola representou, num primeiro momento, a luta por um direito vinculado ao mundo do trabalho. Desse modo, a escola, expressando a real interdependência entre as aspirações dos trabalhadores e suas condições de vida, foi percebida, primeiramente, como uma instituição que garantia a sua sobrevivência, por ser uma necessidade gerada pelas condições gerais de produção e por ser uma promessa de mobilidade social; num segundo momento, os objetivos da classe trabalhadora se tornaram predominantes, e a luta por uma nova proposta de escola a vinculou a uma concepção distinta das relações 
de produção, manifestando preocupação com a resolução de problemas que aconteciam no trabalho e com a segurança e a atualização do trabalhador.

Os movimentos sociais por educação escolar enquanto decorrência das chamadas contradições urbanas foram abordados por Rogério Cunha Campos (1989), em pesquisa realizada na área industrial de Belo Horizonte e Contagem, como instrumento de defesa da classe trabalhadora, sob um duplo aspecto: tanto no propósito de obter conhecimentos que permitiriam a seus filhos melhorar de vida, quanto no propósito de lutar pela posse da terra. Nesse último aspecto, Campos mostra que a conquista da escola significava uma mediação para a permanência, uma vez que os trabalhadores residentes nas vilas da região industrial resistiam às tentativas de expulsão com dois argumentos poderosos: a escola para os filhos e o trabalho para os adultos. Por outro lado, a reivindicação por educação escolar levava a outras reivindicações, tais como: transporte, asfalto, iluminação pública, segurança, revelando, para os próprios trabalhadores, que a democratização das oportunidades educacionais não se limitava a ela mesma, mas supunha a democratização de todos os aspectos implicados na vida das camadas mais empobrecidas da população na cidade, representada pelo acesso aos equipamentos sociais urbanos.

Tendo como referência a década de 70, em que a luta por educação escolar empreendida nas grandes cidades esteve associada aos moradores de bairros periféricos no empenho pela aplicação dos recursos públicos em serviços e equipamentos de consumo coletivo, Rogério Cunha Campos (1992) decidiu investigar, dez anos depois, em sua tese de doutoramento, a situação da escola pública a que tinha acesso as camadas subalternas da Região Metropolitana de Belo Horizonte e os movimentos por educação escolar, em 
continuidade a seu trabalho anterior. Detendo-se no período 1987-1989, na administração estadual de Newton Cardoso, o autor constatou a desestruturação do sistema público de ensino, com a atuação do Estado restringindo os direitos sociais, a que se opuseram as associações de moradores aliados aos trabalhadores do ensino. Estes, na avaliação de Campos, por sua crescente relevância política, podem desempenhar importante papel na produção de propostas alternativas para a educação escolar, inserindo-se no amplo espectro das lutas sociais urbanas contra a deterioração das condições coletivas de vida na cidade. Desse modo, o olhar prospectivo do autor leva-o a atribuir aos movimentos sociais de base local, constituídos já a partir da década de 70, o papel de sujeitos políticos da cidade.

Em pesquisa realizada na periferia do município de São Paulo, Sérgio Avancine (1990) acompanhou a trajetória de um grupo de mães desde suas primeiras articulações, no início dos anos 70, com as Comunidades Eclesiais de Base, até sua participação no Conselho de Escola de seus filhos, em meados dos anos 80. Assim, a inexistência de vagas em escolas dos bairros de Vila Remo e o completo descaso das autoridades governamentais pela manutenção dos poucos prédios escolares instalados levaram as mulheres dos Clubes de Mães a se dirigirem à opinião pública e a unificarem suas lutas em torno da questão escolar. Tomando uma escola da área como um caso em estudo, Avancine mostrou que, quando as mães conseguiram se fazer presentes em instância gestora da instituição escolar, essa presença foi objeto de permanente questionamento, ora pelos diretores que se sucediam, ora pelos professores mais conservadores. Nesse sentido, embora a presença de pais de alunos no Conselho de Escola tivesse sido duramente conquistada e tivesse o reconhecimento oficial dado pela legislação da época, a participação das mães no cotidiano da escola em questão era admitida, pela 
direção e pelos professores, essencialmente sob uma perspectiva utilitária, para resolver, por exemplo, problemas de segurança da escola e de relacionamento com jovens estudantes.

Maria das Graças Ribeiro (1990) focaliza as lutas por educação no movimento de bairros do Rio de Janeiro com o propósito de verificar como os militantes das associações de moradores filiadas à Federação das Associações de Moradores do Estado do Rio (Famerj) entendem a questão da educação pública escolar como uma de suas reivindicações e que tipo de ação desenvolvem em prol dela. Cobrindo o período de 1978 - quando foi fundada a Famerj - até meados de 1989, a autora constata que a escola, enquanto um dos equipamentos de consumo coletivo da população, estava entre os problemas específicos e imediatos que levaram grande parte dos militantes a procurar as associações de moradores. No entanto, porque a escola não era a prioridade principal para a população dos bairros pobres do Rio - sendo superada pela moradia, pelo saneamento, e pelo transporte - , as reivindicações de natureza mais qualitativa, relacionadas ao currículo escolar, à avaliação e à própria gestão ficavam restritas às lideranças do movimento. Nesse contexto, a autora propõe - apoiando-se no conceito de hegemonia de Gramsci - que as lideranças empenhem seus esforços na elaboração de uma nova cultura política, que sirva como um instrumento de emancipação das classes populares, levando-as, entre outros ganhos, a participar mais efetivamente da luta por educação.

Maria do Carmo Bomfim (1991) registra a luta dos trabalhadores dos bairros Lourival Parente e Vila São Francisco (Sul) pela escola pública em Teresina/PI como parte da luta das camadas populares por condições básicas de vida no espaço urbano destituído 
de meios coletivos de consumo. Nos embates, a presença de outros atores - agentes pastorais da Igreja Católica progressista, grupos de teatro, grupos de jovens, jovens do movimento estudantil, etc. - , ao lado dos próprios moradores, dá aos movimentos a feição de um jogo relacional com o poder hegemônico, em que as contradições e as mediações se fazem presentes. Embora se caracterizando como experiências de resistência e solidariedade diferenciadas, as lutas desenvolvidas pelos trabalhadores dos dois bairros terminam por provocar a expansão do atendimento da demanda escolar com a construção de prédios públicos, o que significou uma conquista para os moradores no que se refere ao acesso ao conhecimento e à possibilidade de ascensão social.

Indagando-se sobre a influência que lutas populares de bairro poderiam exercer sobre a participação na escola pública, Elie Ghanem Jr. (1992) decidiu investigar um importante movimento regional por moradias da periferia da cidade de São Paulo para saber se práticas desenvolvidas nas diversas formas de associativismo condicionavam uma intervenção planejada e organizada sobre as escolas oficiais. Uma significativa constatação do trabalho é a de que a precariedade dos serviços escolares na região praticamente não acarretava ações coletivas intencionalmente constituídas como tais, que se complementava com a absoluta inexistência de projetos de intervenção nas escolas próximas por parte das associações locais. Em conseqüência, a relação entre a instituição escolar e a associação popular degradava-se para uma forma de relação personalizada - de indivíduos usuários com a pessoa encarregada do serviço público que se articulava com a atitude refratária da direção da unidade escolar ao relacionamento com representantes de interesses da população local. Desse modo, os diretores puderam conduzir a participação dos usuários na escola de modo subordinado, basicamente sob a forma de prestação de serviços. 
Carlitos Fuchs (1992) buscou reconstituir as lutas dos trabalhadores pelo acesso à escola pública em São Leopoldo/RS, no contexto em que mais da metade da população não era natural do município, tendo passado por todos os problemas associados ao processo de expansão das periferias já aqui relatados. $\mathrm{O}$ estudo destaca a prática do mutirão como forma de cooperação trazida do meio rural para as vilas e bairros pelos migrantes que, na cidade, foi utilizado pelos órgãos públicos para compensar a retração do Estado na criação e na manutenção dos meios coletivos de consumo. Mostra, ainda, que a luta pela escola pública esteve condicionada à impossibilidade de os migrantes sustentarem as chamadas escolas comunitárias e também à sua percepção da educação escolar tanto como um direito social quanto como uma possibilidade de inserção mais favorável no mercado de trabalho. No que se refere às perspectivas que se apresentam aos trabalhadores, o autor ressalta a criação de uma nova sociabilidade, que pode contribuir para reforçar a noção de grupo e de classe aplicada à construção de uma inédita identidade de interesses.

Marcando uma diferença em relação aos trabalhos aqui apresentados, o Movimento Estadual Pró-Educação (MEPE), enquanto singular expressão das muitas lutas que a população de São Paulo empreendeu por educação, não esteve ligado às reivindicações de moradores de bairro. Composto, em sua origem, por um grupo de mães pertencentes a setores das classes médias, cujos filhos estudavam em escola pública da rede estadual, e que desejavam a melhoria da qualidade do ensino, o MEPE era resultado do interesse de algumas poucas moradoras, embora, mais tarde, a estas viessem se juntar setores organizados das classes populares. A trajetória do MEPE foi acompanhada por Cláudia Vianna (1992), desde seus primeiros momentos em 1988 até a etapa em que buscou 
permanência e consolidação dois anos mais tarde, após ter adquirido visibilidade social. A reconstituição da identidade do movimento, através da apreensão das relações significativas entre suas participantes - sua face interna - e através da interação com aqueles que se constituíram em seus adversários ou eventuais aliados - sua face externa - representou outro aspecto inovador do estudo, em que se reconhecia a solidariedade e o conflito como elementos significativos da dinâmica de construção da identidade coletiva.

O Movimento de Amigos de Bairros de Nova Iguaçu/RJ e sua luta por educação a partir dos primeiros anos da década de 80 foi o objeto de estudo de Márcio Vieira (1994). Surgido em 1976 como o maior movimento municipal de bairros do estado do Rio de Janeiro, o Movimento de Amigos de Bairros de Nova Iguaçu (MAB) tinha, entre suas reivindicações no campo da educação, o acesso a uma escola pública de qualidade, a democratização do ensino e o passe livre para o estudante. No início dos anos 80, sob uma conjuntura política mais favorável, o MAB encampou a luta por eleições diretas para diretor nas escolas públicas estaduais e municipais do Rio, juntamente com a Famerj - Federação das Associações de Moradores do Estado do Rio. No entanto, o próprio estabelecimento de uma democracia formal nos anos 80 contribuiu para que houvesse um arrefecimento das mobilizações, na medida que as reivindicações eram atendidas. Em decorrência, na década de 90, a atuação do MAB se modificou, com a adesão a movimentos como o da "Ética na Política" e o da "Campanha contra a Fome e pela Cidadania".

Tendo em vista verificar se as relações construídas nos processos de mobilização em uma unidade escolar da periferia de Diadema eram capazes de provocar alterações na 
função educativa da escola, Teise Garcia (1995) recuperou as representações dos atores - diretora, professores, funcionários, mães e alunos - a respeito de sua vivência no interior da unidade escolar para confrontá-las com a prática desses mesmos atores. A luta por um novo prédio escolar explicitou perspectivas diferenciadas em que a diretora, os professores e as mães se opuseram aos alunos, oposição que se acentuou com ocorrências de violência na escola, protagonizadas por um estudante. Assim, os episódios de violência acabaram por evidenciar as dificuldades que tinha a escola em gestar um projeto educativo direcionado a seus usuários. Como uma conclusão mais geral do trabalho, a autora constata que, na unidade escolar em questão, o esforço para mobilizar ganhava centralidade em detrimento da discussão sobre os objetivos e as funções da escola, que deveriam ter a criança e o jovem como elementos centrais do processo educativo.

O trabalho de Ana Maria Caldas (1995) buscou analisar a construção cotidiana do processo de gestão escolar articulada ao processo de luta por educação escolarizada e não-escolar em uma escola pública estadual da cidade de São Paulo. A partir da história da conquista das melhorias do bairro onde estava situada a escola, pôde-se rastrear os usos, as práticas e os saberes utilizados pelos grupos que interferiam no dia-a-dia da unidade escolar: as associações de moradores, o Clube de Mães, o Grupo de Jovens, o pároco local; desse modo, ao recuperar o sentido histórico das relações que mantinham, centradas na vida e nas necessidades da escola e do bairro, podia-se reconstruir alguns conteúdos sociais que uniam ou separavam tais grupos: “ [uma] escola com aula, com 'ensino forte', sem professores faltosos", e com flores; e uma forma de educação nãoescolar existente no bairro, a de uma entidade conveniada à Prefeitura. Em decorrência, a Reunião do Conselho de Escola constituía-se instância de gestão coletiva em que se 
lutava tanto pela educação escolarizada quanto pela educação não-escolar, e em que se trabalhava no limite do equilíbrio de forças entre o pessoal da escola e seus usuários.

A experiência de Terezinha Cravo como agente pastoral da Igreja Católica esteve na origem de seu estudo sobre a participação popular no bairro Maria Ortiz em Vitória/ES (Cravo, 1995). No início da década de 80, as lutas sociais nesse bairro de periferia coincidem com o surgimento de um projeto de urbanização do Banco Mundial, que requeria a criação de uma associação de moradores para acompanhá-lo. No período da urbanização, entre as principais reivindicações da Associação de Moradores estavam vagas em uma escola municipal e em uma creche que estava sendo construída. Na creche, em continuidade à forma de atuação coletiva assimilada na experiência do movimento social, ocorre a institucionalização da participação popular sob a forma de um modelo de gestão democrática restrita ao grupo dos funcionários. Mais tarde, este grupo vai perdendo a autonomia em conduzir a unidade pré-escolar, o que concorre para que a autora possa imputar às relações burocratizadas a culpa pelo fracasso de uma gestão democrática.

Marina Palhares (1995) analisa a luta por melhores condições de vida dos moradores de dois bairros populares da cidade de São Carlos/SP - em que se inclui a luta por educação - , constatando que as conquistas se deram através da articulação tensa entre duas lógicas: a lógica do direito e a lógica do favor. Com o auxílio do método da intervenção sociológica, a autora confrontou, na situação de laboratório, pessoas que manifestavam posições divergentes em relação às reivindicações, com o propósito de apreender as orientações dos projetos sociais que os interlocutores representavam, explicitando-as para eles próprios. Esse confronto revelou que "as relações entre 
moradores militantes, portadores de um projeto político que se contrapõe ao projeto político excludente [...], se imiscuem com as relações que estes mesmos moradores, exfuncionários, amigos, compadres, como pessoas, mantêm com as pessoas representantes do poder local: seus conhecidos, ex-patrões, amigos e compadres”. (p.8) Nesse sentido, as lógicas do direito e do favor, situando-se lado a lado, tensamente, concorrem para que a conquista de melhores condições de vida na cidade oriente a prática dos moradores, levando-os a construir uma maneira de "caminhar em direção à cidadania num universo relacional". (p.9)

O imaginário social da luta de um grupo de pais e mães pelo acesso a uma escola pública estadual de Salvador/BA constituiu-se objeto singular de investigação para Leliana Santos de Sousa (1996). Considerando que o imaginário é a alavanca propulsora da própria luta, porque está no discurso, nas relações sociais, no processo educativo, nas contradições de cada sujeito, a autora constata que ele se apresentou para esses pais e essas mães, primeiramente, como desejo de uma escola onde, de fato, seus filhos pudessem aprender. Uma vez conquistada a escola, foi a participação no cotidiano escolar que moveu esses pais e essas mães no propósito de ocupação do espaço institucional, cujos limites foram sendo colocados nas relações com o pessoal da escola através das representações reveladas e das representações que foram sendo construídas. Nesse sentido, o resultado da luta apontava para a implementação da gestão colegiada, como decorrência da transposição do imaginário do espaço privado para o espaço público, assumindo os pais e mães o papel social de pais e mães na escola pública.

A relação que se estabeleceu entre os governos municipais e as organizações de bairro em Cuiabá, no período de 1986 a 1996, sob o parâmetro das reivindicações populares 
por educação escolar; da análise das propostas e dos discursos relativos ao setor educacional e à participação popular contidos nos planos de governo; e da opinião de dirigentes de bairro, foi objeto de estudo de Imar Queiroz (1998). O acompanhamento de três gestões municipais, com perfis político-ideológicos distintos, levou o autor a constatar que o alto índice de reivindicações populares por educação escolar registrado nos jornais de Cuiabá correspondeu a um governo que não incentivou a participação direta, até mesmo desativando os espaços de participação popular criados na gestão anterior. Nos outros dois governos, a criação de canais privilegiados para a participação política das organizações de bairro ocasionou um arrefecimento das mobilizações populares por educação, chegando até, em um deles, a gerar uma crise entre o executivo e o legislativo devido à neutralização dos vereadores como mediadores entre o prefeito e a população.

O trabalho de Jaqueline Moll (1998) aborda a trajetória de um grupo popular na luta por escola em um bairro da periferia de Porto Alegre/RS, desde meados da década de 50, considerando as ligações possíveis entre a organização comunitária e os processos educativos que nela estão envolvidos. A autora observa que a luta por escola ocupa lugar central e "constelador" de significados no enfrentamento dos problemas sociais cotidianos, o que acaba por condicionar as interfaces entre a educação das crianças e jovens do bairro e a educação de adultos: assim, "as lutas travadas em torno da escola e o trabalho empenhado para sua criação, permanência, legalização, ampliação e sustentação produzem vínculos que a definem como traço identitário da comunidade e como referência concreta da legitimidade para ocupação do pedaço". (p.236) Conseqüentemente, é o espaço escolar que possibilita a remissão para o espaço urbano, onde se constituem os cidadãos, participantes e sujeitos coletivos da vida social. 
As dissertações e teses aqui apresentadas, ao incluírem em seu objeto de estudo a luta de pais e mães pelo acesso à educação e pela melhoria da qualidade do ensino no contexto dos movimentos sociais urbanos, fazem referência - ainda que, muitas vezes, não façam menção explícita - a uma identidade coletiva concebida de forma genérica. Assim, nos trabalhos, a identidade coletiva encontra-se referida a uma ação coletiva, que expressa um projeto compartilhado na defesa de interesses comuns, que implica também a existência de um interlocutor/opositor. Mas não se observa a identidade coletiva sendo definida em relação ao problema da ação coletiva, que, fazendo-a resultar das circunstâncias em que a ação coletiva ocorre, revelasse uma preocupação propriamente teórica com os movimentos sociais. A única exceção está no trabalho de Cláudia Vianna (1992) que, reconstituindo a identidade do Movimento Estadual Pró-Educação, através das relações significativas entre suas participantes e da interação com seus adversários ou eventuais aliados, recompõe, no Movimento, seu caráter de processo, e restabelece a identidade como uma instância em permanente construção.

Embora os trabalhos aqui arrolados digam respeito à participação de pais e mães na democratização do acesso à educação, parte deles ignora o papel do gênero na determinação de características mais específicas dos movimentos, confirmando observação feita por Marília Carvalho e Cláudia Vianna (1995). Desse modo, ainda que muitos trabalhos registrem a importância da participação feminina nas lutas, seus autores privilegiam o emprego do masculino genérico para se referirem aos pais e às mães, não atentando para a pseudoneutralização lingüística de termos como 'pais', ‘responsáveis', ou mesmo 'família'. Outros procedem à distinção de gênero, mas não o 
exploram em suas análises. No entanto, alguns trabalhos reconhecem a influência do gênero nas determinações sociais dos movimentos e o fazem assinalando que a presença da mulher dona-de-casa e mãe nos movimentos reivindicatórios promove a articulação dos espaços privado e público, conforme Campos, 1982; Spósito, 1993; Vianna, 1992; Palhares, 1995; e Moll, 1998.

\section{Movimentos sociais: a elaboração dos teóricos}

A preocupação epistemológica dos estudiosos dos movimentos sociais levou-os a examinar os movimentos com uma perspectiva eminentemente teórica, para privilegiar neles seus aspectos conceituais.

Assim, Marisa Revilla Blanco (1994), em artigo no qual procura precisar o conceito de movimento social, considera os movimentos sociais como "processos de construção social da realidade", que buscam (re)constituir uma identidade coletiva, "fora do âmbito da política institucional, e pelos quais se dota de sentido a ação individual e coletiva." (Revilla Blanco, 1994, p.181-182) Ao destacar o caráter processual dos movimentos sociais, a autora institui dois níveis de análise sob os quais, segundo ela, os movimentos devem ser estudados: os processos de identificação coletiva, que devem procurar investigar como os indivíduos constituem um "nós", sujeito da ação; e os processos de produção de sentido social da ação, que devem procurar estabelecer o significado que os atores atribuem à sua ação. Nas palavras de Revilla Blanco:

"Quando definimos o movimento social como um processo, estamos fazendo referência a um conceito aberto, inacabado, que parte do presente e se dirige para o futuro, a uma construção que se realiza no tempo. Estabelece-se, portanto, que uma análise do movimento social não pode abordá-lo partindo de uma concepção fixa, de interesses pré-estabelecidos e sujeitos a um padrão de preferências inalteráveis no tempo. Cada 
momento (definido por coordenadas espaço-temporais) do movimento articula o já dado (como passado no presente) e o que se está dando (o presente como futuro potencial)." (Revilla Blanco, 1994, p.201-202)

De modo análogo, para Norma Osores (1997), a identidade, ainda que seja o conjunto de representações do eu pelo qual o sujeito comprova que é sempre igual a si mesmo e diferente dos outros, não é uma entidade fixa e acabada. Isto porque as representações são categorias mentais - pelas quais o sujeito dá significado às múltiplas percepções, sensações e interações da vida cotidiana - que se formam através de um processo contínuo, que cada pessoa vai reajustando ao longo de sua vida, dando coerência à sua existência e estabelecendo uma ponte entre a experiência individual e a vida social.

As particulares caracterizações defendidas por Revilla Blanco dos movimentos sociais como processos e por Osores da identidade como construção histórica, que não se dão sob formas institucionalizadas, e que, portanto, não se deixam apreender em configurações estáveis e consolidadas, coincidem com a caracterização assumida por Alberto Melucci acerca dos movimentos sociais.

Para Melucci (1997a), deve-se considerar o movimento social sempre como um ponto de chegada e não como um ponto de partida. Isto significa dizer que a unidade e a homogeneidade com que os atores sociais se apresentam na cena social devem ser sempre tomados como resultado de processos sociais, decorrente do fato de que, em cada manifestação empírica de um fenômeno coletivo, estão sempre presentes muitos (e diversos) níveis da realidade social, muitas (e diversas) orientações da ação. Assim, torna-se relevante para a análise do movimento social compreender os processos pelos quais os indivíduos se envolvem na ação coletiva e os processos pelos quais se produz a unidade entre os diversos significados presentes em um fenômeno coletivo, para que se 
possa reconstituir sua integridade a partir dos elementos diferenciados que o compõem. Em resumo, para Melucci, o sujeito coletivo não é um dado porque a identidade coletiva é uma configuração possível, resultante de processos sociais diversificados.

\subsection{Identidade}

Em Il gioco dell'io, Melucci (1992) afirma que a identidade, seja aquela que diz respeito ao indivíduo seja aquela que se refere ao grupo, apresenta três características, a saber: continuidade de um sujeito ou de um grupo, para além das variações no tempo e das adaptações ao ambiente; delimitação desse sujeito ou grupo em relação aos outros sujeitos ou grupos; e capacidade de reconhecer-se e de ser reconhecido.

De acordo com Loredana Sciolla (1983), o termo 'identidade' começou a fazer parte do vocabulário contemporâneo, incorporando-se à linguagem política e à linguagem culta, como decorrência de sua difusão pelos meios de comunicação de massa. Sua propagação fez com que o termo adquirisse um significado auto-evidente que acabou por tornar dispensáveis especificações ou aprofundamentos semânticos; hoje, são expressões de uso corrente: crise de identidade, identidade religiosa, identidade feminina, a própria identidade pessoal, etc. No entanto, Sciolla alerta para o fato de que a noção de identidade remete a problemas bastante complexos, encontrando-se "no ponto de interseção de quase todas as ciências humanas e sociais: a filosofia, a psicologia, a antropologia, a história e a sociologia.” (Sciolla, 1983, p.8)

Deixando de lado as quatro primeiras abordagens - por não ser de interesse específico deste trabalho - , e me restringindo ao ponto de vista da sociologia, nesta, a reflexão sobre a identidade se coloca como uma possível solução para o problema posto pela 
relação indivíduo-sociedade, na forma de uma via para o restabelecimento da ligação entre dois pólos: o grau de liberdade do ator social - sua autonomia apoiada sobre a subjetividade - e as constrições impostas pela estrutura social - que o condiciona a ser apenas um elemento funcional no interior de um sistema orgânico.

Loredana Sciolla (1983), ao reconstituir as principais contribuições para se pensar o tema da identidade no campo da sociologia, considera como as três mais importantes correntes teóricas que ajudaram a elaborar o conceito: o interacionismo simbólico, o funcionalismo e a fenomenologia social (cf.Vianna, 1999).

No que se refere ao interacionismo simbólico, seus adeptos dão ênfase aos processos de interpretação em vigor na interação social, destacando os significados das coisas - tanto aqueles já estabelecidos no ambiente social quanto aqueles passíveis de manipulação e modificação por parte dos atores sociais - como resultado de um processo reflexivo que acaba por transformar também o eu (self) em objeto para um sujeito, o ator social (Mead, 1934). Em outras palavras, o interacionismo simbólico lembra que o indivíduo, por viver em sociedade, vive as situações sociais não apenas com base no significado consolidado em que as coisas se apresentam para ele, mas ainda com base no significado das coisas que se originam das interações com seus semelhantes. Desse modo, o indivíduo, ao definir o significado das coisas, define também o significado de seu próprio eu tornado objeto (coisa).

Tomando uma perspectiva diferente, o funcionalismo privilegia a dinâmica que o indivíduo representa para o perfeito funcionamento da sociedade entendida como um organismo social. Para Talcott Parsons (1983), por exemplo, a identidade é resultante de 
um bem sucedido processo de integração social. Em sua teoria geral da ação, com a qual pretende explicar o funcionamento geral da sociedade, Parsons destaca o indivíduo como o centro de um sistema de papéis que se agregam paulatinamente a ele através do processo de socialização. Desse modo, a socialização colocaria o indivíduo em sistemas interativos múltiplos, dos quais emergeria sua personalidade como resultado de um duplo processo: primeiramente, um processo de diferenciação de papéis, seguido por um processo complementar de integração desses papéis. Nesse sentido, Parsons concebe a identidade como o "aspecto estrutural da personalidade do indivíduo concebida como um sistema." (Parsons, 1983, p.70)

Pelo seu lado, a fenomenologia social ressalta a "relação dialética entre as realidades estruturais e o empreendimento humano de construir a realidade na história" (Berger e Luckmann, 1995, p.243), a partir da experiência individual em uma situação social particular. Para Peter Berger, Brigitte Berger e Hansfried Kellner (1983), a identidade é parte essencial de uma específica estrutura da consciência individual que não se encontra apartada do ambiente social, pois o indivíduo, ao mesmo tempo em que tem consciência de si mesmo tem também consciência da sociedade, realizando uma dupla apreensão fenomenológica. Segundo os autores, particularmente na sociedade moderna, diante da extrema pluralização de mundos de significados e de experiências, a identidade toma a forma de um produto social bastante instável, o que a destina, paradoxalmente, a ser permanentemente um projeto, reagindo sobre a estrutura social dada, para mantê-la ou modificá-la.

No que diz respeito à identidade como uma problemática especificamente moderna, esta perspectiva da fenomenologia social difere fundamentalmente daquela do 
funcionalismo. Para Parsons - que é o principal representante desta última linha - a diferenciação social trazida pela modernidade atinge principalmente a estrutura ocupacional e as diversas agências de socialização (Parsons, 1983). As profundas mudanças vividas então pela moderna sociedade industrial acarretam uma multiplicidade e uma diversidade de papéis a serem desempenhados pelo indivíduo, trazendo para este problemas de coordenação e de integração. No entanto, segundo Parsons, embora mudem os conteúdos, isto é, os significados concretos que a identidade deva organizar, sua função de orientação subjetiva, enquanto sistema de significados, permanece invariável. Em outras palavras, ao compreender a sociedade como um sistema regulado que sempre tende à integração, Parsons concebe a identidade como a dimensão estruturada de um subsistema da ação - a personalidade individual - que sempre tende à unificação.

Outra é a interpretação da fenomenologia social ao problema trazido pela modernidade à identidade. Para Peter Berger, Brigitte Berger e Hansfried Kellner (1983), por exemplo, a identidade na sociedade moderna industrial é essencialmente fragmentada. Ao compreender o mundo da vida como um "mapa" de significados oriundos do conjunto de conhecimentos e de esquemas de interpretação, que é progressivamente interiorizado pelo indivíduo através do processo de socialização, e que o orienta na ação, os autores constatam que a pluralização do mundo da vida, que acompanha a modernização da sociedade, traz para a socialização do indivíduo uma ruptura irreparável: a desintegração de uma ordem simbólica que dava inteireza e harmonia à experiência do indivíduo. Assim, a identidade - definida como "a experiência real de si mesmo em uma particular situação social” (Berger et al., 1983, p.179) - é afetada pelo multiplicar-se das referências simbólicas, que decorre da vida urbana e da exposição aos 
meios de comunicação de massa, fazendo com que o homem moderno experimente a sensação de "não se sentir em casa", em um mundo cuja integridade e plausibilidade se encontram permanentemente em questão.

Em se tratando dos condicionantes da identidade individual na sociedade moderna, Alberto Melucci (1996) traz também a sua contribuição para se pensar o problema da identidade, ao chamar a atenção para a extensa e intensa exposição do indivíduo aos recursos cognitivos e relacionais trazida pela produção e pelo consumo de massa e pela generalização dos sistemas de informação. De acordo com Melucci, a informação é um recurso simbólico de sistemas que estão assentados em uma base material de algum modo sólida e que supõem práticas simbolizadoras capazes de construir representações que podem ter vida própria, o que significa dizer que a informação só se constitui em recurso na exata medida em que existe habilidade humana para percebê-la, para processá-la e para elaborar a partir dela. No entanto, segundo o autor, essa ampliação do campo dos recursos tem um caráter ambivalente: ao mesmo tempo em que traz a possibilidade de as pessoas se pensarem a si mesmas como indivíduos - em outras palavras, traz a possibilidade de construção de uma identidade autônoma - , cria uma nova forma de desigualdade social, uma vez que o acesso àqueles recursos se dá de modo diferenciado. Nas palavras de Melucci:

\footnotetext{
"Atualmente, devemos pensar em desigualdade e classes sociais não em termos simplesmente materiais, mas mais em termos de acesso desigual aos novos recursos de individuação. Novas formas de controle, manipulação e exclusão aplicam-se a indivíduos e grupos diferentemente por razões que poderíamos chamar de 'estruturais'. A privação desse potencial de se tornar indivíduos não é igualmente distribuída, mas antes manifesta a estrutura de dominação. Porém, se nos referirmos ao sistema como um todo, essa individuação é uma possibilidade que é prometida a todos, potencial e simbolicamente disponível para cada indivíduo, além de necessária para que o sistema funcione.” (Melucci, 1996, p.213)
} 
Desse modo, a identidade, como expressão da produção social e cultural do indivíduo enquanto indivíduo na modernidade, encontra-se afetada, simultânea e paradoxalmente, por processos de autonomização e subordinação, o que dá origem a novas formas de conflito colocadas pelas novas formas de poder que controlam a distribuição dos recursos de individuação.

Em Il gioco dell'io, Melucci (1992) tematiza a metamorfose do eu em um mundo moderno marcado pela complexidade, decorrente da ampliação do campo de sua experiência. De acordo com Melucci, a freqüência e a velocidade das mudanças e o alargamento das possibilidades de ação trazidos pela sociedade complexa ${ }^{11}$ situam o indivíduo em uma multiplicidade de pertencimentos - tanto de posições sociais quanto de grupos de referência - tornando ainda mais complicado o processo de desenvolvimento da identidade individual. Considerando os resultados de pesquisas de natureza sociológica, que mostram que o desenvolvimento da identidade individual acontece em uma relação circular com um sistema de delimitação, Melucci constata que, frente a uma sociedade espantosamente mutável, torna-se extremamente penosa a articulação dos múltiplos elementos do presente com aqueles do passado, para dar unidade e continuidade a uma biografia individual. Mas se a instabilidade da sociedade dificulta a configuração de uma identidade individual no eixo vertical da linha de tempo, também no eixo horizontal se observam os dilemas dessa identidade. No que se refere ao eixo horizontal, a unidade pessoal se apóia sobre a possibilidade de situar-se no interior de um sistema de relações, o que significa dizer que a "auto-identificação

\footnotetext{
${ }^{11}$ Melucci reconhece o impasse teórico que vivemos, hoje, ao tentarmos definir a sociedade fazendo uso de uma série de adjetivos para especificar características fundamentais da sociedade contemporânea, tais como: pós-industrial, capitalista tardia, pós-moderna, de informação, complexa, etc. Para ele, embora estejamos nos referindo a uma sociedade diversa daquela moderna, não nos encontramos, ainda, capacitados para defini-la em termos analíticos apropriados e teoricamente significativos. (Melucci, 1997a)
} 
deve gozar de um reconhecimento intersubjetivo para poder fundar a nossa identidade." (Melucci, 1992, p.36-37) Mas isto nos coloca em uma situação paradoxal em que cada um de nós tem de afirmar a sua diferença enquanto indivíduo, sem deixar de perceber-se similar aos outros indivíduos. Levando ao extremo seu raciocínio, Melucci chega a afirmar que, diante da dificuldade de se lograr um equilíbrio entre vetores em permanente tensão entre si, "a identidade tende a desfazer-se de conteúdos estáveis e a coincidir com a pura capacidade simbólica de reconhecimento" (Melucci, 1992, p.42), o que significa dizer que iremos reconhecer apenas em nossa capacidade de ação aquilo que nos identifica como indivíduos em relação com os outros.

Ao situar a identidade em um equilíbrio instável entre a definição que damos de nós mesmos e o reconhecimento que os outros nos dão, Melucci retira desta qualquer resquício de essência - a identidade sob a forma de uma instância acabada, definida de uma vez por todas - e lhe dá uma configuração de campo - a identidade sob a forma de um campo de relações - , o que lhe permite criar um termo particular para designar esse processo de construção auto-reflexivo da definição de nós mesmos: identização. Portanto, porque somos nós a construir a nossa consistência e a nos reconhecer no interior dos limites colocados pelo ambiente e pelas relações sociais, somos nós próprios constrangidos a realizar escolhas, a dar a partida ao processo de individuação o que nos confirma como sujeitos autônomos de ação e de criação de sentido para as coisas.

\subsection{Identidade coletiva, teorias da ação e movimentos sociais}

A reflexão contemporânea sobre a identidade, ao trazer em seu bojo uma discussão sobre a subjetividade do ator social, recoloca a questão do sentido da ação social, isto é 
da ação orientada com base em um sentido construído socialmente. Isto porque, na impossibilidade de se proceder a uma separação entre os aspectos propriamente individuais e os aspectos propriamente relacionais e sociais da identidade, esta acaba por se definir como um produto de nossa ação e, também, como um resultado de nossa reflexão, no interior de um sistema de relações. Se assim é na dimensão individual da identidade, quando se leva em conta sua dimensão coletiva, percebe-se que uma concepção da identidade, associada a toda uma série de estratégias e de lógicas que caracterizariam a ação dos sujeitos na sociedade contemporânea, pode se tornar vigente.

Nesse sentido, Marisa Revilla Blanco (1994) reconhece enfoques teóricos que se ocupam do estudo dos movimentos sociais e que consideram a ação coletiva como estratégia. Sob essa perspectiva, o destaque é dado ao aspecto de como atua e se mobiliza um determinado setor da população, em detrimento das causas que levam aquele setor a se mobilizar. Assim, o movimento social é enfocado como organização, sem que se questione a origem de tal organização, isto é, sem que se explique como os sujeitos individuais se tornam um coletivo.

Dentre as teorias contemporâneas que procuram explicar o comportamento coletivo na esteira das transformações políticas ocorridas na sociedade norte-americana nos anos 60 destaca-se a Teoria da Mobilização de Recursos (McCarthy e Zald, 1977). Rejeitando as motivações de ordem pessoal, tais como os sentimentos e os descontentamentos, e as ideologias, para explicar os movimentos sociais daquela época, os teóricos da Mobilização de Recursos se inspiraram na teoria do utilitarismo econômico para restringir a interação entre os indivíduos a uma interação baseada em uma lógica racional - a rational choice. Para os teóricos da Mobilização de Recursos, o grupo de 
interesse em que se constitui um movimento social pode ser visto como uma organização que compete por fontes de recursos e oportunidades, buscando atingir metas e objetivos em estratégias que avaliam os custos e os benefícios das ações.

Do ponto de vista de alguns estudiosos dos movimentos sociais, a fragilidade da teoria da Mobilização de Recursos está em subestimar os relacionamentos e as filiações que tão poderosamente marcam as escolhas que o indivíduo faz. Assim, Debra Friedman e Doug McAdam (1992) ressaltam a importância que a identidade coletiva tem para a participação do indivíduo e para a vida de um movimento social uma vez que a identidade expressa um engajamento, associado a um pronunciamento público de status: "participar de uma identidade coletiva é reconstituir o eu individual em torno de uma nova e valiosa identidade; $[\ldots]$ nesse sentido, identidades coletivas funcionam como incentivos seletivos motivando à participação.” (Friedman e McAdam, 1992, p.157) Para esses autores - que pretendem superar tanto a perspectiva da rede de relações quanto a da escolha racional na interpretação dos movimentos sociais - , a constituição de uma identidade coletiva, no entanto, pode levar o movimento à morte, como resultado da perda do controle sobre a "provisão seletiva" daquela identidade, ao transformar a identidade coletiva em "bem público”, disponível para qualquer um.

A emergência de novas formas de ação coletiva nos últimos anos - por exemplo, os movimentos pela paz, pelos direitos das mulheres, os movimentos ecológicos, os movimentos estudantis, etc. - levou alguns pesquisadores a um esforço teórico para repensar o conceito de identidade coletiva e restabelecer sua centralidade no estudo dos movimentos sociais. Hank Johnston, Enrique Laraña e Joseph Gusfield (1994), ao constatarem que os estudos sociológicos sobre os movimentos sociais oscilaram, 
durante todo o século vinte, de uma perspectiva que privilegiava o viés ideológico a outra que privilegiava a racionalidade da ação nos movimentos, sugerem uma alternativa em que as duas posições seriam abandonadas em favor de uma terceira que pudesse abordar os novos movimentos sociais com um conceito mais preciso de identidade e com instrumentos metodológicos mais refinados. Para justificar a mudança de parâmetro, os autores ressaltam o "duplo aspecto de novidade e abrangência e de magnitude e relevância de tais movimentos" (Johnston et al., 1994, p.9), que "freqüentemente envolvem aspectos pessoais e íntimos da vida humana" (p.8) e que estão associados a um conjunto de crenças, símbolos, valores e significados socialmente construído a partir da vida cotidiana.

\subsection{Identidade coletiva, ação coletiva e movimentos sociais}

O papel relevante desempenhado pela identidade coletiva, tanto em teorias da ação social quanto em estudos dos movimentos sociais, pode ser imputado ao seu potencial explicativo dos fenômenos coletivos. Para alguns teóricos, particularmente em relação à ação coletiva, a identidade do ator coletivo representa a possibilidade de sua instauração.

Nesse sentido, Marisa Revilla Blanco (1994), ao levar em consideração as relações, os significados e as orientações da ação presentes nos fenômenos coletivos, procede a uma distinção conceitual entre comportamento coletivo, ação coletiva e movimentos sociais. Apoiando-se nos trabalhos de Alberto Melucci, Revilla Blanco destaca a identidade coletiva como o elemento fundamental que define o movimento social e que o distingue do comportamento coletivo (cf.Vianna, 1999). 
Para ela, comportamento coletivo expressa uma confluência, no espaço e no tempo, de ações individuais que não carrega dentro de si uma agregação de vontades individuais com um sentido dirigido a outros. Assim, as ações dos inúmeros indivíduos, nos fenômenos de comportamento coletivo, têm orientação de natureza atomizada, embora a proximidade no espaço e no tempo das ações individuais possa fazer supor que o fenômeno tenha orientação integrada da ação. Exemplos de comportamento coletivo são as reações coletivas de pânico e as modas.

Quanto à ação coletiva, esta expressa uma ação conjunta de indivíduos para a defesa de interesses comuns, o que implica a existência de um interlocutor/opositor e de um processo de identificação que sustenta um projeto compartilhado. A ação coletiva supõe, portanto, a existência de identidade, que é a capacidade de os atores reconhecerem e serem reconhecidos como partes da mesma unidade social, e a existência de conflito, que colocam os atores frente a um interlocutor/opositor na defesa de seus interesses. O grupo de pressão é um exemplo de ação coletiva.

No que se refere aos movimentos sociais, estes são considerados tipo específico de ação coletiva em que a reapropriação do sentido da ação individual e coletiva efetuada no processo de identificação faz romper os limites de compatibilidade do sistema de relações sociais, impedindo que uma negociação se estabeleça entre os participantes do movimento e seus interlocutores. A ação coletiva, nesse caso, procura subverter a posição relativa dos atores no sistema de relações sociais, ao colocar em questão a autoridade do adversário social e a legitimidade dos procedimentos instituídos para o controle dos recursos ou valores disputados. 
De acordo com a perspectiva teórica adotada aqui - representada pelos trabalhos de Alberto Melucci - , tratar da identidade coletiva significa, então, situar a identidade em um campo particular de relações que envolve processos de formação da identidade do ator coletivo, definindo-se a identidade primordialmente em relação ao problema da ação coletiva.

Para esse debate, Alessandro Pizzorno (1983) traz a sua contribuição, ao dialogar com os teóricos da Mobilização de Recursos, criticando o paradigma utilitarista que reduz a interação entre os indivíduos a uma interação baseada em uma lógica racional e a ação coletiva a uma estratégia que avalia os custos e os benefícios na busca de fontes de recursos e oportunidades. O autor parte do princípio de que o indivíduo não é um eu unitário com preferências claras e um interesse único e específico, antes vivendo uma situação de incerteza valorativa permanente. Sendo assim, Pizzorno supõe que, para que a contabilidade dos custos e benefícios das ações seja bem sucedida, tem de haver um mercado socialmente específico que possibilite calcular os investimentos na mobilização, mas esse mercado não pode ser o mercado da informação, pois não vivemos em condições de informação perfeita. Para Pizzorno, é apenas a identidade coletiva que pode garantir esse mercado, mas uma identidade coletiva que não se constitui instância cristalizada, antes se construindo (e se reconstruindo) no próprio processo da ação. Desse modo, a ação coletiva é um processo de identificação, pelo qual um indivíduo se inscreve em um círculo de reconhecimento, que lhe permite dar uma certa continuidade aos valores pelos quais estabelece suas preferências e suas expectativas (cf.Vianna, 1999). Nesse sentido, pertencer a uma identidade coletiva reforça a própria identidade pessoal e é na própria identidade coletiva onde se define a coincidência entre o interesse coletivo e o interesse individual. Nas palavras de 
Pizzorno: "se alguém tenta [obter] os benefícios derivados da ação coletiva sem pagar os custos da participação, acaba por permanecer simplesmente sem reconhecimento." (Pizzorno, 1983, p.140)

Em artigo no qual se ocupa em refletir sobre a identidade, Alain Touraine (1983) registra o caráter ambíguo da noção. Segundo ele, do ponto de vista sociológico, a noção identidade remete a uma definição não-social do ator, tornando-se um apelo à vida, à liberdade, à criatividade, em oposição aos papéis sociais (cf.Vianna, 1999). Em seus estudos sobre os movimentos sociais, Touraine os concebe como a ação de um grupo, um ator coletivo, que, como agente dinâmico, produtor de reivindicações e demandas, se opõe a um adversário em torno de um conflito central no interior de um dado tipo de sociedade (Touraine, 1985). Para ele, os movimentos sociais são fruto de uma determinada forma de produção e organização social, que, por meio de uma relação de dupla dimensão - de identidade e de oposição - , contesta a lógica da ordenação social, buscando um novo modo de integração na sociedade (princípio de totalidade). Touraine reconhece que, nos dias de hoje, crescem os clamores à especificidade, à diferença, ao nacionalismo, enfim, a cada forma de identidade. Mas essa forma de defesa (contra o controle social), segundo ele, não pode tornar-se um movimento, nem simplesmente produzir uma capacidade de ação coletiva, a não ser que se associe a um movimento de contra-ofensiva. Tal contra-ofensiva, no entanto, está muito longe da idéia de identidade, porque tem um caráter político e apela ao conceito de autodeterminação e de democracia social e cultural. Portanto, se da perspectiva sociológica, o ator é definido por suas relações sociais, o apelo à identidade deve deixar em plano secundário a simples recusa da definição social dos papéis desempenhados 
pelo ator mesmo, para colocar em primeiro plano o conceito de autodeterminação e de democracia social e cultural:

"o apelo à identidade pode ser concebido como um trabalho da democracia, como a consciência do esforço através do qual os atores de uma sociedade, que exerce um forte poder sobre si mesma e que está empenhada em contínuas mudanças, procuram determinar as condições de sua vida coletiva e pessoal.” (Touraine, 1983, p.166)

Assim se revela, de acordo com Touraine, "a dupla face da identidade": defensiva e ofensiva.

As dimensões ressaltadas por Pizzorno e Touraine no que se refere à identidade coletiva podem sugerir questões que conduzem ao próprio processo de construção do ator coletivo, isto é, questões que dizem respeito às interações, às negociações que envolvem os atores, e que podem dar origem aos movimentos sociais.

Em relação a Pizzorno, de fato, se a identidade coletiva se constitui no próprio processo da ação coletiva, como um processo pelo qual o indivíduo se inscreve num círculo de reconhecimento, é de se supor que esta identificação inaugure uma nova forma de reconhecimento que se contrapõe a uma identificação anterior que já não serve mais como referente. Assim, poder-se-ia investigar, em situações concretas, como se constrói uma identidade coletiva, isto é, como se constitui um ator coletivo em oposição a um adversário identificado, que detona os limites de compatibilidade do sistema de relações sociais, levando à configuração de identidade distinta das que já existem.

Em relação a Touraine, os três elementos constitutivos de um movimento social - a saber: o ator, seu adversário e o que está em jogo no conflito - pressupõem uma situação de dominação que pode ser investigada, também em situações concretas, para que se 
possa perceber a movimentação real dos atores no jogo das forças sociais antagônicas. Touraine refere-se a isto ao defender uma análise sociológica que, ao abordar o estudo dos movimentos sociais, não os identifique simplesmente com a luta pelo poder no campo de ação do Estado, buscando, ao invés disso, "reencontrar sempre [...] as orientações do sistema de ação histórica e as relações de classe.” (Touraine, 1973, p.357)

Nesse sentido, Alberto Melucci propõe uma teoria da ação coletiva que fundamente a análise dos movimentos sociais como um sistema de orientações que estrutura a própria ação. Embora reconheça o destaque que Touraine deu ao conflito, conflito que define as relações entre as classes sociais não apenas no terreno econômico mas ainda no terreno cultural, o que implica, por parte dos atores, "uma vontade de controle e de direção de um processo global de mudança histórica" (Touraine, 1973, p.115), Melucci observa que mesmo dessa perspectiva os atores sociais, que são os sujeitos na história, que são os artífices dos movimentos sociais, não são levados em conta em termos de sua dinâmica interna, em termos daquilo que internamente constitui e mantém sua ação. Em outras palavras: sob essa perspectiva, os movimentos sociais não são fundados teoricamente como objeto, limitando-se a ser tão-somente um efeito da conjuntura ou da situação histórica.

Para Melucci, os fenômenos coletivos são "processos nos quais os atores produzem significados, comunicam, negociam, tomam decisões." (Melucci, 1987, p.32-33) Assim, a ação coletiva, como resultado de um processo negociado, deve ajustar, pelo menos, três ordens de orientações: sobre os fins, sobre os meios e sobre as relações com o ambiente, em torno das quais os atores devem fazer frente a múltiplas exigências. 
Enquanto movimento social a ação coletiva expressa um sistema de ação multipolar: é a conjugação entre os fins (o sentido que a ação tem para os atores), os meios (as possibilidades e os limites da ação) e as relações com o ambiente (o campo no qual a ação se realiza) que configura uma ação e, conseqüentemente, uma identidade coletiva (Melucci, 1991).

Melucci não desconhece a importância das situações conjunturais no surgimento dos fenômenos coletivos, mas lembra que essa influência não poderia acontecer "se o ator não tivesse a capacidade de percebê-la e integrá-la em um sistema de orientações que constituem a estrutura mesma da sua ação.” (Melucci, 1987, p.35)

Segundo o pesquisador, a motivação para participar varia de acordo com as diferenças psicológicas individuais e com os traços de personalidade, determinando-se, no entanto, na interação social. O que significa dizer que é a partir da rede de relações que unem os indivíduos que as disposições pessoais singulares destes podem conformar-se para construir uma identidade coletiva. Nesse aspecto, concorre para a disponibilidade do indivíduo à participação em um movimento coletivo a sua maior ou menor exposição a determinados recursos cognitivos e relacionais, como, por exemplo, a estrutura dos incentivos, aos quais se atribui e reconhece valor a partir da rede de relações que ligam os indivíduos. São esses recursos, que Melucci chama de recursos de identidade, que permitem aos indivíduos desenvolver orientações, fazer escolhas e tomar decisões (Melucci, 1987).

No que se refere às relações sociais entre os atores na ação coletiva, Melucci ressalta o seu caráter interativo e compartilhado, o que significa dizer que a identidade coletiva se 
apresenta como uma instância permanentemente em construção, condicionada por um processo que supõe investimentos contínuos:

"Chamo identidade coletiva uma definição interativa e compartilhada que muitos indivíduos produzem em relação às orientações da ação e ao campo de oportunidades e de vínculos nos quais a ação se coloca: interativa e compartilhada significa construída e negociada através de um processo repetitivo de ativação das relações que ligam os atores." (Melucci, 1987, p.46)

Nesse sentido ainda, a ação coletiva tem o "caráter de um processo que deve ser continuamente ativado para tornar possível a [própria] ação.” (Melucci, 1987, p.47)

A preocupação de Melucci em tomar o movimento social como objeto de análise, e não apenas como objeto empírico, leva-o a dialogar com algumas correntes teóricas que consideram o movimento social como uma entidade unitária, com uma estrutura definida e homogênea. Para ele, em grande parte dos casos, trata-se de fenômeno heterogêneo e fragmentado, que destina muitos de seus recursos para gerir as diferenças internas, e ao qual a teoria deve corresponder tentando explicar como se forma e como se mantém um sujeito coletivo da ação. Nesse esforço, Melucci compreende que não basta, para caracterizar um movimento social, que os atores sejam capazes de se reconhecerem e de se serem reconhecidos como parte da mesma unidade social. Tornase necessário que essa identidade coletiva - que expressa um tipo de solidariedade entre os atores - seja constituída em um embate que represente um tipo específico de conflito; é um conflito que coloca em campos opostos adversários que disputam o controle e o destino de recursos fundamentais. Nas palavras de Melucci: “um movimento social é a mobilização de um ator coletivo, definido por uma solidariedade específica, que luta contra um adversário pela apropriação e pelo controle de recursos valorizados por ambas as partes.” (Melucci, 1991, p.20-21) 
Mas existe, ainda, segundo o pesquisador, mais uma condição - além da solidariedade e do conflito - para que se possa caracterizar um fenômeno coletivo como sendo um movimento social: a ruptura dos limites de compatibilidade do sistema de relações sociais. Isto significa dizer que um movimento não apenas manifesta um conflito, mas o faz indo além dos limites do sistema de referência representado pelas relações sociais no qual a ação se situa. Um movimento social, portanto, "rompe com as regras do jogo, propõe objetivos não negociáveis, coloca em questão a legitimidade do poder." (Melucci, 1991, p.21)

Insistindo na necessidade de se tomar o movimento social como categoria de análise, que recusa as explicações fundadas sobre a condição estrutural comum dos atores (que lhes concederia uma unidade e homogeneidade prévias), Melucci (1991) remete o problema da formação e da manutenção de um sujeito coletivo a uma teoria da ação que leve em conta as duas vertentes deste processo: a complexidade interna do ator social, que se expressa na pluralidade de orientações que o caracteriza, e as suas relações com outros atores, em um campo de oportunidades e de vínculos. Sendo assim, a construção e a manutenção de uma identidade coletiva supõe continuidade nos investimentos relacionais e afetivos e se apresenta como um processo no qual as razões para estar e permanecer juntos dependem de escolhas e de decisões, elaboradas ou descobertas socialmente.

Melucci registra que, via de regra, nos movimentos, a atenção do observador é atraída pelos seus aspectos mais visíveis, tais como as passeatas, os atos públicos, o enfrentamento com violência, o que favorece a identificação entre o fenômeno empírico e sua objetificação analítica, levando o observador a considerar os movimentos como 
ponto de partida e não como ponto de chegada. Introduzindo-se no campo da construção simbólica, Melucci ressalta que o movimento está presente muito antes da mobilização visível, pois ele precisa contar com a existência de um discurso previamente construído, com uma orientação da ação e com uma rede de solidariedade previamente constituídas. Melucci propõe, então, que se considere ambos os aspectos:

\begin{abstract}
"os movimentos sociais não podem ser restringidos a um nível visível que, embora seja essencial para sua existência, sobrevivência e efeitos coletivos, não constitui a 'raison d'être' desses movimentos. Esses são encontrados naquelas redes subterrâneas em que tudo que se torna manifesto quando a mobilização ocorre já estava presente, moldado e, por assim dizer, nomeado." (Melucci, 1996, p.218)
\end{abstract}

Ao retirar do agir coletivo o caráter de uma simples intenção acabada, e revelar nele o caráter de um processo em que os atores negociam e re-negociam continuamente os recursos disponíveis dentro dos limites e possibilidades colocados por um certo ambiente, Melucci (1997a) mostra que a unidade exibida por uma ação coletiva na verdade supõe, no que se refere aos atores sociais, uma pluralidade de orientações e campos de referência da ação, uma variedade de estruturas de relações e uma diversidade de níveis da realidade social.

Para os objetivos desta Tese, as observações de Melucci abrem a possibilidade de se considerar um momento que antecede à projeção na cena pública das mobilizações coletivas, no qual as diferentes orientações da ação, os seus diversos campos de referência, as diferentes estruturas de relações ainda não tomaram a configuração de um arranjo uniforme - a identidade coletiva - e em que, portanto, a participação dos atores se caracteriza essencialmente enquanto processo nos seus aspectos diferenciados e heterogêneos. 


\section{Capítulo 2}

\section{A ampliação da participação dos pais e mães, a luta pela extensão dos direitos e a particípação em canais institucionais}

\section{Ação coletiva e comunidade}

No contexto dos movimentos sociais urbanos na década de 70 , uma das dimensões da luta pela redemocratização da sociedade brasileira dizia respeito à questão da participação dos pais de alunos na gestão das escolas públicas, forjando, no universo semântico da educação, o conceito de "comunidade escolar", como sendo o conjunto de alunos, pais e mães de alunos, professores e funcionários que deveriam ter seus interesses defendidos e representados junto à direção das unidades escolares - seu sentido amplo - ou se reportando apenas àqueles que não trabalham na escola, mas que se utilizam dos seus serviços - seu sentido restrito.

Essa referência à "comunidade escolar" para legitimar a participação dos pais de alunos na gestão das escolas públicas foi sugerida, decerto, pelas próprias características assumidas pelos movimentos sociais urbanos. De fato, sob o aspecto sócio-político, os "novos" movimentos sociais surgem no Brasil, organizando os interesses da população em torno de demandas relacionadas com a sua sobrevivência diária - água, luz, transporte, escola, etc. - nas quais se privilegiavam os laços primários de solidariedade expressos nas relações de vizinhança, parentesco, compadrio ou amizade.

Nesse sentido, a coletividade nos movimentos sociais tinha na igualdade na carência o seu elemento definidor: para Eunice Durham, é uma negatividade específica, que "recobre a heterogeneidade das positividades (dos bens, das capacidades, do trabalho e 
dos recursos culturais)" - a igualdade na carência (Durham, 1984, p.28), que conforma uma "comunidade". De modo análogo, também para Ruth Cardoso, a comunidade é uma experiência de igualdade: "o que define a comunidade é uma experiência comum de discriminação que enfatiza o compartilhar de certas carências, percebidas como injustas" (Cardoso, 1984, p.231, grifo no original). Mas não é apenas a coletivização das carências individuais que expressa a experiência de igualdade dos participantes dos movimentos sociais, tendo ainda que se considerar que a consolidação dos laços diretos entre as pessoas ocorreu também em face de seu desamparo diante das instituições mais amplas da sociedade. ${ }^{12}$ (Brant ,1981)

Segundo Ilse Scherer-Warren (1987), é no aspecto sócio-cultural que se encontra o elemento identificador dos movimentos sociais. A pesquisadora destaca a assimilação pelo povo de uma cultura crítica que, se inspirando no anarquismo e tirando proveito dos seus princípios - de democracia de base, de livre organização, de autogestão, de direito à diversidade e de respeito à individualidade - , cria "formas comunitárias de participação direta das bases ao nível da reflexão, da decisão e da execução" (SchererWarren, 1987, p.42). A esse modo peculiar de organização dos movimentos sociais também Durham (1984) chama modelo “comunitário", no qual é indesejável a institucionalização da representação e que, portanto, demanda a participação permanente de todos.

A introdução do ideário da democracia participativa nas mobilizações populares do período teve decisiva contribuição da Igreja Católica através das Comunidades Eclesiais

\footnotetext{
${ }^{12}$ Ruth Cardoso tem posição semelhante ao lembrar o caráter relacional da identidade: "Cada grupo social desenvolve sua identidade afirmando-se e distinguindo-se de outros grupos. Não existe um 'nós' senão frente a 'eles', os outros.” (Cardoso, 1988, p.14)
} 
de Base - CEBs. Fundamentadas na Teologia da Libertação que marcou a opção pelos pobres, as CEBs, enquanto organizações voluntárias apoiadas pela Igreja, tinham como um de seus objetivos interpretar os problemas enfrentados pelos membros da comunidade à luz da bíblia, em um ambiente de relações fraternas em que se incentivava a participação e no qual se expandia o espaço de ação dos leigos no culto e na pregação do Evangelho. Por reunir número relativamente pequeno de participantes a partir de grupos de vizinhança, as CEBs deflagravam uma reflexão conjunta sobre os problemas do bairro e possibilitavam o crescimento da experiência coletiva (Jacobi, 1990). Nesse sentido, a vivência nas Comunidades tinha o significado de um verdadeiro aprendizado político, em que se exercitava a prática do voto, em que se mobilizava para o engajamento, em que se assumia a responsabilidade pela execução de uma tarefa, e em que se avaliava aquilo que havia sido feito.

Na opinião de Tilman Evers (1984), esse aspecto político, estimulado pelas Comunidades Eclesiais de Base nos movimentos sociais urbanos da década de 70, não era o mais importante. Para ele, o elemento "novo" dos novos movimentos sociais está na criação de pequenos espaços de prática social cotidiana nos quais o poder não é fundamental e onde os sujeitos se constituem permanentemente, recolocando em outros termos a dimensão da "comunidade" nos movimentos. A possibilidade de renovação de padrões sócio-culturais e sócio-psíquicos do cotidiano, criada pelos novos movimentos sociais através do estabelecimento de relações mais solidárias e de manifestações culturais menos alienadas, representava, para o autor, um "elemento estranho dentro do corpo social do capitalismo periférico" (Evers, 1984, p.15). 
Em que pesem as divergências a respeito da dimensão em que se define comunidade (sócio-econômica, sócio-cultural ou sócio-política), o que importa destacar aqui é que a literatura sobre os movimentos sociais atribuiu a esse coletivo de pessoas, que se congregam sustentando um projeto compartilhado, uma ação conjunta na defesa de interesses comuns, em oposição a um interlocutor assim identificado.

\section{A luta pela extensão dos direitos e a particípação dos pais e mães em canais institucionais}

No campo da educação, a luta das camadas populares pela democratização da gestão insere-se em um contexto em que o Estado brasileiro se reorganiza para atender as exigências suscitadas pelas novas determinações sócio-político-econômicas trazidas a partir dos primeiros anos da década de 80 com a redemocratização do país.

Para isso contribuíram não apenas a pujança dos movimentos sociais da década anterior mas também a incipiente atuação dos partidos de oposição e das entidades representativas dos docentes, que, podendo, agora, usufruir da tímida liberdade que acompanhou o processo de abertura política, aproveitam os ainda pouco estruturados espaços públicos para fazer suas reivindicações.

Assim, com a restauração da democracia, e em resposta às exigências da sociedade, novas formas de gerenciamento das políticas públicas passam a orientar as agências governamentais, que começam a aceitar a idéia da participação institucional de pais e mães, por exemplo, nos Colegiados ou Conselhos de Escola e no processo de eleição de dirigentes das unidades escolares. Em alguns casos, a democratização da gestão não se 
limitou, apenas, ao âmbito das unidades escolares, mas chegou a alcançar as instâncias intermediárias e centrais do sistema educacional.

No que se refere à democratização da gestão da escola pública, sua importância na autonomia da unidade escolar foi destacada por Vitor Henrique Paro, que mostra que o envolvimento e a participação de servidores e usuários nas atividades da escola concorrem para que ambos os segmentos estejam comprometidos nas decisões que dizem respeito aos rumos da instituição escolar, agora elevada à condição de "sujeito social”. (Paro, 1996b, p.42)

A justificar esse comprometimento coletivo está a natureza específica do produto da educação escolar, que implica uma real transformação na personalidade do educando, fruto de sua participação ativa no processo educativo como "sujeito da educação". (Paro, 1996a, p.142) Contrapondo-se à concepção tradicional que percebe o aluno somente como objeto do processo produtivo escolar, Paro ressalta nele a sua natureza humana que, transcendendo o puramente natural, faz com que responda à intencional ação transformadora do professor com sua própria participação no processo. Desse modo, justifica-se a participação dos servidores e dos usuários na escola porque, uma vez que o aluno é também co-produtor no processo produtivo escolar - e não apenas seu objeto - , todos aqueles interessados nos resultados daquele processo podem (e devem) colaborar para que a avaliação do desempenho da escola seja feita de forma contínua, percorrendo todas as suas atividades e procedimentos. (Paro, 1995)

A participação dos usuários - não apenas os efetivos, mas também os potenciais - na escola tem, ainda, uma justificativa suplementar que diz respeito ao caráter público da 
atividade educativa mantida pelo Estado. Isto porque se os usuários em geral são aqueles a quem, supostamente, mais importa a qualidade do ensino oferecido pelo Estado, há que se garantir a universalização de um ensino de boa qualidade por meio do controle democrático da escola, como forma de pressão sobre o poder público. (Paro, 1997) Assim, a participação dos usuários na escola institui um acompanhamento sistemático das atividades e dos procedimentos que ocorrem em seu interior, compelindo o Estado a cumprir o seu dever de oferecer à população escolarizável uma boa educação escolar.

Nesse contexto, a forma de pressão da escola sobre o poder público tem maior eficácia se expressar, de fato, a existência de um processo de democratização da gestão da unidade escolar. Com efeito, a criação de canais institucionais de participação, tais como os Colegiados ou os Conselhos de Escola, com a presença de pais, alunos, professores e demais funcionários da escola, permite à unidade escolar se fazer representar junto às autoridades estatais com muito mais força, se comparada à força que possa personificar o diretor da escola. Pois, no dizer de Vitor Paro,

“é mais difícil dizer 'não' ao pedido da escola, quando a reivindicação não for de uma pessoa, mas de um grupo, que represente outros grupos e que esteja instrumentalizado pela conscientização que sua própria organização propicia". (Paro, 1996b, p.114)

De modo análogo, também a eleição direta para a escolha do dirigente da escola pública responde à necessidade de controle democrático da escola por parte da população, ao condicionar a atuação do diretor ao compromisso com o interesse de todos - pais, alunos, professores e demais funcionários da escola - e, conseqüentemente, à recusa de formas tradicionais de dominação política, marcadas pelo servilismo e pela troca de favores. 
Em que pesem as decorrências positivas da eleição direta de diretores na eliminação da habitual influência dos agentes políticos, que, desse modo, se vêem impedidos de nomear seus apaniguados, não se observa, efetivamente, o total desaparecimento das práticas clientelistas, que se manifestam tanto no próprio processo de eleição quanto na vigência do mandato do diretor eleito. No entanto, o fato de essas expectativas não se cumprirem não invalida, em absoluto, as eleições diretas como forma de provimento do cargo de dirigente da unidade escolar, visto que, conforme ressalta Vitor Paro, as práticas clientelistas "nada mais são do que remanescentes de uma cultura tradicionalista que só a prática da democracia e o exercício autônomo da cidadania poderão superar”. (Paro, 1996b, p.103)

Nesse sentido, avalia-se o impacto do sistema eletivo sobre a qualidade da educação, na medida que se concebe a educação escolar de modo mais alargado, como um processo que permeia todas as relações sociais que ocorrem na escola, e que abrange a aquisição e o domínio de valores de cidadania e o desenvolvimento de comportamentos condizentes com a colaboração recíproca entre os homens. (Paro, 1996b)

Em resumo, a luta pela democratização da gestão da escola pública - tanto no que se refere à constituição dos colegiados ou conselhos escolares quanto no que se refere à eleição direta para escolha dos dirigentes das unidades - insere-se em um contexto em que estavam ausentes relações humanas de solidariedade e cooperação. Com efeito, o caráter hierárquico da distribuição do poder e da autoridade no interior da escola, estabelecendo relações verticais de mando e de submissão, constituía fator institucional 
que, conjugado a outros fatores internos à escola, dificultava a participação dos usuários pelos inúmeros obstáculos que colocava a esta ${ }^{13}$.

Assim, se, a partir dos anos 80, a constituição dos colegiados ou conselhos de escola e as eleições diretas para escolha dos dirigentes escolares expressavam a luta pela democratização da gestão da escola pública, em resposta à necessidade de democratização do país exigida pela própria sociedade, era de se esperar que a literatura acadêmica na área da educação acompanhasse esse processo, o que, de fato, aconteceu.

Na década de noventa, essa literatura passa a se ocupar mais da gestão do sistema de ensino através dos canais institucionais, deixando em segundo plano estudos que tratavam da luta pelo acesso à educação e pela melhoria da qualidade do ensino.

O Conselho de Escola ou, sob outra denominação, o Colegiado Escolar, e, ainda, a Associação de Pais e Mestres foram objeto de investigação de inúmeros trabalhos acadêmicos nos anos 90, que procuravam analisar, seja nas instâncias estaduais, seja nas instâncias municipais, seu funcionamento, para avaliar seu efetivo papel no processo de democratização da gestão escolar.

Sob a vigência da lei que instituiu o Conselho de Escola Deliberativo nas escolas estaduais paulistas, Maria de Lourdes Von Gal (1991), Maria Salete Genovez (1993), Daniel Flores (1996), Delfina Villela (1997) e Manoel Guerra (1998) se ocuparam em identificar os limites e as potencialidades que a atuação do Conselho apresentava para a

\footnotetext{
${ }^{13}$ Para uma compreensão mais aprofundada dos condicionantes internos e externos à participação da população na escola, ver Paro, 1997.
} 
administração democrática pela via da participação dos diferentes segmentos que nele tinham assento.

Assim, Von Gal (1991) evidencia, através da pesquisa histórica, os obstáculos à participação da comunidade na gestão da escola, uma vez que a formação cultural do povo brasileiro, sob o peso do autoritarismo, poderia emperrar o funcionamento do Conselho de Escola Deliberativo, não fazendo jus à "modernidade administrativa e pedagógica" que o havia instituído. Em consonância com os condicionantes históricos, a pesquisa de campo, efetuada em uma escola pública paulista de $1^{\circ}$ grau, constatou que o não funcionamento do Conselho, ou sua atuação apenas nos aspectos burocráticos, advinha das barreiras impostas pelo diretor: "O autoritarismo da função e o desconhecimento da idéia de participação faz com que os diretores, em sua maioria, rejeitem-no.” (p.127) Embora considere que o Conselho de Escola seja um caminho para deflagrar as transformações que a escola precisa incorporar à sua estrutura - e por esta razão mesma - Von Gal sugere que as instâncias superiores a que a escola está vinculada viabilizem oportunidades de reeducação de seus dirigentes.

O Conselho de Escola Deliberativo como um foro para o exercício da participação foi objeto de análise de Genovez (1993), que buscou obter subsídios, pela identificação dos fatores que dificultavam a atuação do Conselho, para princípios e práticas que reorientassem o seu funcionamento. O estudo de documentos legais relativos ao Conselho de Escola, conjugado a uma análise criteriosa de sua prática, evidenciada em atas de reuniões realizadas em escolas de Bauru, no período de 1988 a 1990, permitiu a Genovez afirmar que o Conselho pode contribuir para a construção de uma escola cogestionada. No entanto, a autora conclui que se torna necessário que a prática ritualística 
do Conselho, meramente formal ou arbitrária, constatada nos documentos analisados, seja superada por mecanismos mais eficientes de informações sobre seu funcionamento e seu papel no contexto escolar, se se pretende que o Conselho seja um espaço para a aprendizagem da democracia.

Daniel Flores (1996) estudou o funcionamento dos Conselhos de Escola de duas escolas estaduais localizadas no município de Osvaldo Cruz/SP, no período de 1986 a 1994, para conhecer as razões que facilitavam ou dificultavam sua atuação. Ao constatar, pela análise dos documentos consultados, que ambos os conselhos exerciam suas atribuições parcialmente, o autor observa que estes, raramente, debatiam e deliberavam sobre assuntos de natureza pedagógica. Nas entrevistas, professores, pais e alunos mencionavam a postura autoritária dos diretores, que se sentiam ameaçados em seu poder, em decorrência da delegação de competências que o Conselho propiciava. Do mesmo modo que Genovez, Flores registra que grande parte dos integrantes do Conselho nada conheciam sobre suas prerrogativas. Contudo, mesmo fazendo duras críticas ao seu desempenho, os entrevistados defendiam a permanência do colegiado como uma instância que podia viabilizar uma gestão democrática na escola pública.

Os impasses e as perspectivas que se apresentam para o Conselho de Escola como uma instância da gestão democrática na área da educação são registrados por Villela (1997), que investigou as condições internas e externas que facilitavam ou dificultavam a atuação desse colegiado em uma escola pública estadual paulista. Assim, o desconhecimento, pelos membros do Conselho, de suas atribuições, levando-os a aceitar passivamente as decisões emanadas dos órgãos superiores e da própria direção da escola, constituía-se obstáculo interno ao funcionamento do Conselho, que tinha sua 
correspondência externa no burocratismo e no assistencialismo daquelas entidades, o que relegava a participação da comunidade ao plano da simples informação ou consulta. Em relação às condições facilitadoras internas para a atuação do Conselho, Villela destaca a existência de um clima favorável à participação que se articulava a uma débil integração do colegiado com a comunidade, através de alguns de seus líderes. E é justamente essa relação que se apresenta como perspectiva positiva ao funcionamento do Conselho, na medida que a participação popular através de movimentos de bairro pode levar a uma mudança na escola pública, no que se refere à melhoria da qualidade do ensino, do espaço físico e do fluxo contínuo de recursos.

Manoel Guerra (1998), em pesquisa realizada no âmbito de escolas públicas estaduais paulistas jurisdicionadas à Primeira Delegacia de Ensino de Campinas, estudou a atuação dos Conselhos de Escola para verificar sua potencialidade na democratização do poder na unidade escolar. Mostrou, então, que fatores de ordem estrutural, institucional, histórica, legal e intra-escolar emperravam a ação daquele colegiado. Assim, identificava um obstáculo ao funcionamento do Conselho no desenho organizacional da Secretaria de Educação do Estado, que privilegiava os órgãos centrais e estabelecia uma cadeia hierárquica, fortalecendo a burocratização da instituição escolar. No mesmo sentido, impropriedades, imprecisões e lacunas na lei que havia instituído o Conselho de Escola Deliberativo eram objeto de controvérsia entre os administradores, trazendo insegurança na aplicação dos dispositivos da lei. Em que pese esses impedimentos, o autor deu grande ênfase ao papel que os educadores podiam desempenhar na ampliação deste espaço de inclusão e participação representado pelo Conselho de Escola. 
Não apenas o Conselho de Escola, mas, ainda, a Associação de Pais e Mestres foram objeto de investigação de Luci Samartini (1994) para averiguar a possibilidade de pais e alunos terem voz ativa nos processos decisórios administrativos e pedagógicos ocorridos no âmbito da unidade escolar. Em relação aos demais trabalhos que tratam especificamente da democratização da gestão, o estudo de Samartini faz uma importante ressalva quanto à aplicação indiscriminada do termo 'comunidade', preferindo utilizar a expressão 'pais e alunos', mais rigorosa do ponto de vista metodológico. Radicando o processo de trabalho na escola à sua especificidade pedagógica, a autora deduz que esse processo é, em sua gênese e em seu desenvolvimento, participativo, o que quer dizer que os alunos e seus pais deveriam ter o direito de interferir nele, uma vez que a aprendizagem resulta de uma ação interativa entre o aluno e o professor, mas também depende das relações que acontecem em outras esferas da vida do aluno. Após estudar o Conselho de Escola e a Associação de Pais e Mestres de cinco escolas da rede estadual paulista, Samartini define as perspectivas daquelas duas instâncias de deliberação na unidade escolar, constatando que, apesar de serem, ainda, altamente burocratizadas, ambas se encontram na esfera de ação de sujeitos que, cada vez mais, reconhecem seus direitos de vez e voz.

Sob a vigência do Regimento Comum das Escolas, aprovado em 1985 e resgatado em 1989, na administração de Luiza Erundina, que instituiu o Conselho de Escola nas escolas municipais da cidade de São Paulo, Cecília Carvalho (1991), Neísse Montenegro (1991), Margarete Berkenbrock (1993), Theresa Adrião Pepe (1995), Manira Santos (1997), Rubens Camargo (1997) e Ângela Ciseski (1997) se empenharam, não apenas em observar as condições de viabilidade daquele colegiado para uma administração democrática, mas, ainda, em alguns casos (Montenegro e 
Berkenbrock), em analisar o significado do processo de participação para os sujeitos envolvidos.

Cecília Carvalho (1991), tomando como referência duas escolas municipais onde o Conselho de Escola vinha realizando um trabalho com vistas à maior autonomia na definição de seus rumos e na solução de seus problemas, quis certificar-se quanto a essa autonomia no que se refere aos órgãos centrais, e sua possível relação com a efetiva participação dos componentes no Conselho. Embora o estudo de Carvalho, por um lado conclua que a participação deva incluir o autogoverno da escola, em consonância com as suas necessidades e com as aspirações da população que a procura, por outro constata que não se favorece a participação dos pais no Conselho. Assim, o desejo de participar, por parte dos pais, se frustra, requerendo, da parte da escola, o esforço em subsidiá-los com informações para prepará-los para um real engajamento no processo educativo.

Ao contrário da experiência de Carvalho, Neísse Montenegro (1991) registra, com base em um estudo de caso, que a criação de uma Comissão Pedagógica, além de propiciar uma maior aproximação entre professores e pais, permitiu que a atuação do Conselho de Escola se estendesse para o âmbito do planejamento, da execução e da avaliação das atividades educacionais. Embora faltassem aos membros do Conselho esclarecimentos sobre a legislação que regulamenta o funcionamento da escola e sobre o próprio Conselho - o que comprometia sua independência em relação à tutela da diretora ou do pessoal administrativo - , a autora observa que a abertura da escola para a comunidade levou-a a uma identificação com a clientela, que teve sua contrapartida na maior força política adquirida pela unidade escolar, com a formação de um grupo capaz de pressionar os órgãos centrais para o cumprimento de seus compromissos públicos. 
O processo de participação, tal como é percebido pelos pais, mães e responsáveis dos alunos de uma escola pública municipal, em relação à proposta político-pedagógica de Luiza Erundina para a cidade de São Paulo (1989-1992), e tendo como pano de fundo uma sistemática história de exclusão deste segmento no processo escolar, foi o objeto de investigação de Margarete Berkenbrock (1993). Nessa perspectiva, o Conselho de Escola, como um canal institucional de participação, foi considerado de forma positiva pelas mães, que o tomaram como um "espaço para conhecimento da escola, fórum de reivindicações, de tomada de decisões, ajuda nas tarefas da escola e participação". (p.172) Através dos depoimentos tomados, o trabalho estima que esse processo de participação irá contribuir para a construção de uma sociedade democrática em um movimento lento, onde haverá divergências, tensões e resistência, mas que, decerto, avançará porque pautado no diálogo, elemento também fundamental para a construção da democracia na escola.

O Conselho de Escola, enquanto "instância de elaboração, deliberação, acompanhamento e avaliação do planejamento e do funcionamento da unidade escolar", foi analisado por Theresa Adrião Pepe (1995) para evidenciar os princípios contidos nas propostas de democratização da gestão das escolas da rede municipal de São Paulo implementadas durante o governo do Partido dos Trabalhadores nos anos de 1989 a 1992. Assim, os princípios de participação, descentralização e autonomia, que davam sustentação ao propósito de democratizar as relações entre escola e comunidade, articulavam também os Conselhos de Escola aos Núcleos de Ação Educativa, que tinham entre suas atribuições catalisar e atender as demandas das comunidades escolares no bojo das orientações da política educacional do governo. Embora revele os 
limites e as contradições que perpassavam aquelas propostas, a autora não deixa de destacar os possíveis avanços em sua implementação, que iam de encontro às resistências incorporadas nas práticas tradicionais dos agentes envolvidos.

Também Manira Santos (1997) elege como objeto de reflexão a democratização da gestão na política educacional do governo petista da cidade de São Paulo nos anos de 1989 a 1992. Através dos processos de descentralização e de participação, a autora analisa a reestruturação administrativa ocorrida na Secretaria Municipal de Educação, com a institucionalização de fóruns de co-gestão - como os Conselhos de Escola e os Conselhos Regionais de Conselhos de Escola - , destacando o planejamento descentralizado como um recurso de mobilização popular. Desse modo, a participação, como princípio norteador do governo petista, tinha em vista a concretização de novo patamar de cidadania, uma vez que se pretendia inaugurar uma nova forma de governar a cidade, introduzindo novos sujeitos, identificados com a população marginalizada do processo decisório. Como uma conclusão mais geral do trabalho, a autora constata que o empenho da administração para vencer as tradicionais resistências refletiu-se na paulatina ocupação do espaço escolar pela população através do Conselho de Escola.

A análise dos pressupostos e dos condicionantes presentes nos princípios de gestão democrática e de qualidade do ensino da política educacional da Secretaria Municipal de Educação de São Paulo, no período de 1989 a 1992, foi o objetivo principal do trabalho de Rubens Camargo (1997). Observando as condições em que se desenvolveram as ações do Conselho de Escola na rede municipal de ensino, Camargo registra determinantes de natureza material, ideológica, institucional e político-social que, conquanto dificultassem o processo de democratização da gestão escolar, 
mostravam pelo seu reverso a possibilidade de articulação daqueles princípios na construção coletiva de uma nova escola pública. Assim, o Conselho de Escola se destacava como um espaço público privilegiado em que soluções locais podiam ser encontradas, através do trabalho coletivo, do exercício da dialogicidade, na busca da autonomia, e que, representando um espaço político e de construção de cidadania, poderia contribuir para a transformação da escola e da sociedade.

A partir de sua experiência como membro de Conselho de Escola durante os anos de implementação da proposta educacional de Luiza Erundina no município de São Paulo, Ângela Ciseski (1997) propôs-se a identificar os limites e os avanços em relação às práticas de participação vividas anteriormente pela população. $\mathrm{O}$ estudo chega à conclusão de que a administração escolar na perspectiva democrática está a exigir uma nova forma de organização do trabalho na escola, uma vez que a ausência de canais mais ágeis e eficazes para facilitar a comunicação entre os diferentes segmentos que compõem o Conselho e a falta de uma cultura de participação dificultam a gestão participativa. No entanto, existem aspectos positivos na experiência, entre os quais o fato de as escolas poderem criar seus próprios projetos, o que propiciou o resgate da identidade do professor; e o contato que o Conselho de Escola proporcionou com os movimentos sociais do bairro, possibilitando a troca de experiências e a união das lutas.

Os limites e as possibilidades de democratização da gestão das escolas na vigência de legislações que instituíram os Conselhos ou Colegiados Escolares em Mato Grosso do Sul, em Recife/PE, em Pernambuco, em Minas Gerais, em Ouro Preto/MG e em Belo Horizonte/MG foram objeto de estudo, respectivamente, de José Carlos Pesente (1995), 
Maria José Maciel (1995), Elisabeth Francisca de Melo Filha (1998), Lúcia Mattos (1998), Mônica Fernandes (1998) e Miriam Bueno (1994).

José Carlos Pesente (1995) dedicou-se à análise da atuação do Colegiado Escolar criado nas escolas estaduais de Mato Grosso do Sul em 1991 - em três unidades de ensino, levando em conta as determinações legais, a sua trajetória histórica e as demandas específicas das respectivas comunidades escolares. O trabalho registra, no que se refere às limitações do Colegiado, o desconhecimento de suas funções e sua importância por parte dos membros, a centralização do processo escolar efetuada pelo diretor, e a existência de mecanismos de cooptação colocados em prática também pelo diretor ou pelo presidente do colegiado. No que diz respeito às possibilidades que o Colegiado traz ao processo de democratização da escola, o trabalho anota a ocorrência da dissensão que, revelada sob a forma de conflitos e pontos de vista divergentes, serve como contraponto às atitudes corporativistas dos componentes da comunidade interna. De toda forma, Pesente acredita que a ação colegiada é um dos caminhos possíveis para a construção de uma escola democrática, na medida que o caminho para mudanças for construído e reconstruído diariamente, elevando o nível de formação intelectual, técnico e político de todos os componentes do Colegiado.

Maria José Maciel (1995) analisa os processos de institucionalização e de implementação dos Conselhos Escolares na rede municipal de ensino do Recife/PE, selecionando para o estudo nove escolas que tinham Conselhos instalados e funcionando há pelo menos um ano. As experiências foram classificadas em bemsucedidas e malsucedidas de acordo com o funcionamento regulamentar dos colegiados. Enquanto as experiências malsucedidas se assemelhavam pelo fato de os Conselhos 
terem interrompido suas atividades ou funcionarem sem a presença de representantes de alguns segmentos da escola, nas experiências bem-sucedidas não se observava uma real democratização da gestão na unidade escolar. Na única exceção observada, isso acontecia em virtude da presença de representantes de diversos segmentos seriamente comprometidos com a democratização das relações de poder na instituição. Diante desse quadro desolador, no entanto, a autora acredita que a interlocução entre os segmentos, favorecida pelas capacitações promovidas pela Secretaria de Educação, pode fazer com que o Conselho Escolar cumpra a finalidade para a qual havia sido criado.

A criação do Conselho Escolar na rede estadual pública de ensino de Pernambuco, em 1993, no governo de Joaquim Francisco, antecedida pelos debates que prepararam sua implantação, ocorridos no governo Miguel Arraes, foram objeto de atenção de Elisabeth Francisca de Melo Filha (1998). Em que pesem os Fóruns Itinerantes de Educação, que propiciaram uma discussão pública, com diversos segmentos sociais, acerca da necessidade de transformar a escola mediante gestão colegiada exercida no Conselho Escolar, e da subseqüente decretação da lei que instituiu o Conselho Escolar em todas as escolas públicas de Pernambuco, Melo Filha chega à conclusão de que, ao final de dois governos, aquele colegiado não havia conseguido ser um instrumento de autonomia da escola, fosse no aspecto administrativo, fosse no aspecto pedagógico, fosse no aspecto financeiro. Assim, através de um estudo de caso, a autora observa que as decisões ainda eram tomadas, de forma individualizada, pela diretora; que as atividades continuavam a ser desenvolvidas segundo uma hierarquização das funções; e que não havia, da parte da escola, estímulo à participação dos pais dos alunos. 
Lúcia Mattos (1998) propôs-se a analisar o Colegiado de Escola sob duas dimensões: como instrumento de uma proposta democrática da política educacional do governo de Minas Gerais, na gestão 1991/1994, e como instrumento de democratização dos processos escolares no interior das unidades de ensino. Nessa perspectiva, Mattos registra que a concepção de democracia que orientou as políticas públicas de Minas, ao conciliar os interesses sociais por um melhor padrão educacional com os interesses econômico-financeiros do Estado, acabou por propugnar a gestão colegiada como um modelo democrático de administração escolar, que, no entanto, não se concretiza porque, no cotidiano, esbarra na hierarquia tradicional das escolas, onde prevalece a atuação do diretor. Assim, aquilo que é apontado como uma possibilidade do Colegiado Escolar na proposta governamental não se constitui como um fato na práxis da gestão colegiada, porque seus membros mantêm, ainda, uma relação de dependência e de concessões com o diretor da escola e com a Secretaria de Educação.

Os obstáculos e as potencialidades que a gestão colegiada apresenta para a participação da comunidade no processo de gerenciamento da educação pública foram analisados por Mônica Fernandes (1998) por meio da atuação do Colegiado Escolar em quatro escolas municipais de Ouro Preto/MG. Tendo como referência a implantação da gestão escolar participativa naquele município, no período de 1994 a 1997, Fernandes observa que a gestão colegiada é um movimento com avanços e recuos, onde ocorre um processo de aprendizado político dos envolvidos através, não só da compreensão da representatividade, do compromisso com o coletivo, da responsabilidade pelo bem comum, mas também da reflexão permanente a respeito dos desafios a serem enfrentados. Alertada pelo fato de a participação acontecer em um contexto heterogêneo, em que os interesses e as expectativas em relação à escola são 
diferenciados, a autora defende uma aceitação mútua das possibilidades e limitações pessoais dos elementos do colegiado, do seu nível de conhecimento, de experiência e de consciência, se se deseja que o Colegiado Escolar seja um espaço de participação da comunidade.

O Colegiado e a Assembléia Escolar, dentre outros instrumentos legais de participação de pais e alunos no projeto político-pedagógico da Prefeitura de Belo Horizonte de 1989, foram objeto de pesquisa de Miriam Bueno (1994) que buscou apreender os níveis de participação e envolvimento das famílias das camadas populares na escola pública através de um estudo de caso. O pressuposto de que não haveria uma participação uniforme destas porque não se reconhecia no conjunto de pais a assim denominada 'comunidade' apontava para uma indagação a respeito da possibilidade de diálogo entre a escola e as famílias das camadas populares. Em que pese o trabalho ter revelado que as formas de participação das famílias na gestão da escola e no projeto pedagógico são diferenciadas, como decorrência de suas condições sócio-econômicas e culturais e de suas expectativas em relação à escolaridade dos filhos, a autora evidencia a insuficiência dos canais institucionais para a participação na escola e a necessidade de um esforço permanente da instituição para fomentar o envolvimento dos pais e dos alunos.

Não se restringindo ao seu papel no processo de democratização da gestão escolar, mas examinando-se, também, sua contribuição para a prática estudantil e para o sucesso escolar, o Conselho de Escola ou o Colegiado, e, ainda, o Conselho de Classe estabeleceram-se como objeto de estudo, respectivamente, para Edmar Pereira de Souza e Lázara Cristina da Silva. 
O Conselho de Escola Deliberativo, enquanto instrumento da chamada gestão democrática em educação, que vigorou em Mato Grosso em fins da década de 80, constituiu-se parâmetro para Edmar Pereira de Souza (1996) analisar as opiniões de pais, alunos e professores a respeito da influência da participação dos primeiros na prática estudantil em uma escola estadual. Vivenciando épocas distintas em que não havia o Conselho (antes de 1987) e em que este foi desativado (1991), pais, alunos e professores entrevistados dividiram-se, fazendo referência a um período em que a escola fora dirigida com rigidez, mas "funcionava bem porque tinha disciplina e respeito" ("conservadores") e a outro período em que a escola foi dirigida com mais democracia e "funcionou melhor porque houve participação" ("progressistas"). Embora a análise dos depoimentos coletados evidenciasse a positividade da gestão democrática para a prática social dos alunos, Souza mostra que a comunidade escolar não reagiu diante da suspensão daquela gestão, o que ele imputa à forte cultura de não participação observada entre nós.

O Colegiado e o Conselho de Classe como expressões de ações participativas no processo decisório cotidiano da escola e sua vinculação a um trabalho educativo que favorece o sucesso escolar foram objeto de investigação de Lázara Cristina da Silva (1998). Buscando identificar e analisar as concepções de participação e de sucesso escolar, tanto para os profissionais quanto para a comunidade de uma escola pública estadual de Uberlândia/MG, a autora conclui que estas são similares. Assim, observou a predominância de uma participação tutelada, fruto de uma estrutura governamental, que não decorre da necessidade e da vontade da comunidade escolar e local, e, no que se refere ao sucesso escolar, a preocupação com os resultados, tendo por horizonte o 
mercado de trabalho. Nesse sentido, não se registram ações cotidianas voltadas para a formação da consciência política do grupo.

O Conselho de Escola foi analisado por José Marcelino Pinto (1994) à luz da Teoria da Ação Comunicativa de Jürgen Habermas. Assim, no contexto da teoria habermasiana, mecanismos que buscam coordenar a ação através de processos comunicativos que visam alcançar o entendimento - como é o caso do Conselho de Escola - surgem como uma reação de determinados segmentos da sociedade aos processos de mercantilização e burocratização que atingem as esferas públicas e privadas nas sociedades capitalistas contemporâneas. Em pesquisa realizada em uma escola estadual paulista, o autor constatou que, a despeito do papel fundamental que representa a escola na transmissão cultural, na socialização e na construção da personalidade individual, o Conselho, enquanto expressão do "mundo da vida", tinha seu potencial esvaziado pelos constrangimentos sistêmicos impostos pela estrutura administrativa do Estado, que procurava controlá-lo e limitar sua autonomia. Diante deste quadro, Pinto sugere mudanças profundas na forma de gestão daquele colegiado, introduzindo mecanismos de decisão que levem em conta a participação de todos aqueles que sofrem os efeitos de sua ação.

O Conselho de Escola foi, ainda, objeto de estudo de Dener Luiz da Silva (1996), na perspectiva das interações sociais que nele ocorrem. Com o propósito de apreender as particularidades envolvidas na participação comunitária e, eventualmente, esclarecer a natureza do vínculo existente entre esta participação e a dinâmica interna da escola especialmente em seus aspectos educacionais e pedagógicos - o autor selecionou as interações verbais tipo “cara a cara” como um dos focos principais de análise. Deparou- 
se, então, no Conselho de uma unidade escolar da rede estadual de ensino de São Paulo com um conjunto de grupos heterogêneos, com opiniões e posturas diversificadas, o que, segundo o autor, não caracterizava uma participação comunitária. Como uma conclusão mais geral do estudo, Silva reconhece que o Conselho de Escola, a despeito de ser um órgão potencialmente importante para a co-gestão da unidade de ensino, possui ainda limites quanto à consecução desta tarefa, tanto porque não consegue envolver igualmente todos os segmentos da escola quanto porque não se observa, em seu âmbito, a discussão dos temas afetos aos aspectos pedagógicos, pertinentes ao significado último da escola.

Já Marina Fortunato (1998) estudou a Caixa de Custeio Escolar no contexto da EscolaPadrão, entre 1991 e 1995, no estado de São Paulo, enquanto canal de participação articulado a projeto que visava a democratização da escola pública. Prevista no Programa de Reforma do Ensino Público do estado de São Paulo, a Caixa de Custeio vinha proporcionar, segundo seus idealizadores, a gradativa autonomia da escola tanto do ponto de vista pedagógico quanto do ponto de vista financeiro. No entanto, Fortunato observa que a Caixa não dispunha de condições políticas ou técnicas para concretizar a desejada autonomia, porque suas ações permaneceram presas a estruturas extremamente burocratizadas, fazendo com que as verbas chegassem com muito atraso às escolas, dificultando qualquer planejamento. Além disso, na aplicação dos recursos, as unidades escolares, mesmo contando com certa liberdade de escolha, ficavam limitadas às despesas cotidianas e emergenciais, prejudicando o possível desenvolvimento de seus projetos pedagógicos. 
O conjunto dos mecanismos de ação coletiva na rede municipal de ensino de São Paulo - o Conselho de Escola, a Comissão de Classe e a Associação de Pais e Mestres - foi objeto de análise de Eneida Maria Araújo (1997) na perspectiva das possibilidades e dos limites que representam para a democratização da escola. Reconstituindo a história e a atuação desses canais institucionais de participação, a autora mostra que todos eles expressam uma promessa para a gestão democrática da escola pública. Assim, a existência legal do Conselho de Escola enseja o aprendizado de práticas participativas, em que pese sua atuação centrada nos aspectos de cunho burocrático, em detrimento das questões pedagógicas. De modo análogo, a Comissão de Classe, ainda que de forma tênue, oferece condições para que seus membros possam diagnosticar as dificuldades dos alunos e elaborar planos de intervenção para a permanência deles na escola. No que se refere à Associação de Pais e Mestres, a autora acredita que esta possa configurar-se em uma alternativa de participação dos usuários da escola no controle de verbas públicas, na medida que seus membros cobrem do Estado o cumprimento de seus deveres constitucionais.

Os canais institucionais de participação localizados na escola foram considerados mecanismos peculiares para o estudo da gestão democrática na educação através da comparação entre as dimensões teórica e prática da administração educacional por Tânia Maria Rezende Brito, Miguel Henrique Russo e Sena Aparecida de Siqueira.

Tânia Brito (1992) examina os canais institucionais de participação como instância privilegiada para a elaboração de uma proposta de administração participativa e democrática. Confrontando os canais institucionais tais como se encontram na literatura - no bojo dos pressupostos teóricos e das estratégias necessárias ao planejamento, à 
implantação, ao desenvolvimento, ao controle e à avaliação de uma proposta de administração participativa e democrática - com seus possíveis similares em uma escola de primeiro grau do município do Rio de Janeiro empenhada na implementação de uma proposta educacional co-gestionada, a autora pôde sugerir novos encaminhamentos para a superação das lacunas observadas entre a situação ideal e a situação real. Assim, por exemplo, questões relacionadas à resistência à mudança por parte dos professores são apontadas como relevantes para uma efetiva gestão democrática.

O Conselho de Escola, a Associação de Pais e Mestres e o Grêmio Estudantil de uma escola pública estadual paulista, enquanto canais institucionais de participação da comunidade na gestão da escola, foram estudados por Miguel Henrique Russo (1995) para exemplificar a prática gestionária em contraponto com o arcabouço teórico produzido por autores nacionais sobre a administração educacional. Ao observar que os mais importantes entraves à democratização da escola são de natureza subjetiva, que se manifestam por meio de comportamentos determinados por forte carga ideológica, Russo confrontou a teoria e a prática da administração escolar, constatando a existência de um "descompasso entre o pressuposto da práxis administrativa criativa e reflexiva presente na proposta de uma escola voltada para a transformação social e a prática meramente reiterativa e espontânea observada na realidade empírica”. (p.278)

Sena Aparecida de Siqueira (1998) toma os canais institucionais de participação de três escolas do Distrito Federal como expressão da dimensão prática do comprometimento da comunidade na gestão escolar sob duas diferentes propostas de administração educacional. Assim, os processos de tomada de decisão em escola da rede privada de ensino, mantida por associação de pais e professores, e em unidades escolares da rede 
pública do Distrito Federal são comparados para evidenciar pontos confluentes e pontos conflitantes entre a prática e a teoria educacional. O estudo mostrou que, na dimensão teórica, as duas propostas se aproximam pela preocupação com uma educação voltada para a conscientização e para a efetiva participação das famílias e dos alunos, enquanto que, na dimensão prática, a instituição privada e apenas uma das instituições públicas se assemelham porque trabalham em consonância com os princípios da administração humanística.

O Círculo de Pais e Mestres de uma escola estadual de Porto Alegre, enquanto instância institucional de participação, foi considerado por Heloísa Ribeiro (1992) lugar privilegiado para a reconstituição das relações entre pais de classes populares e escola pública, a par das interações que ocorrem no cotidiano. Em que pese a comunidade dos pais ter tomado a iniciativa de fundar aquele colegiado, para que pudesse expressar e viabilizar a demanda por um curso supletivo e um pré-escolar, o estudo de Ribeiro mostra que essa comunidade foi sendo silenciada pelo corpo administrativo e docente da escola, que substituiu a fala dos pais por um discurso que trata da disciplina, das normas e da incompetência dos alunos. Desse modo, no espaço de segregação criado pelo discurso competente da comunidade escolar, as tarefas assistencialistas acabaram por tomar o lugar das tarefas pedagógicas empreendidas pelos pais que, ainda assim, não deixam de almejar um ensino de qualidade para seus filhos.

Ao contrário do observado por Ribeiro, a precária forma de atuação dos Conselhos Escolares de escolas estaduais do Rio Grande do Sul foi ressaltada em pesquisa de Maristela Costa de Oliveira (1998), que buscava investigar o processo de participação na escola. De acordo com a percepção de familiares de alunos atendidos no Programa 
Sócio-Educativo da Área do Serviço Social, no Centro Especializado de Assistência ao Educando localizado na cidade de Porto Alegre, existia uma defasagem entre a participação almejada por eles e aquela permitida pelas escolas, o que levava as responsáveis pelos alunos a sugerir a criação de espaços onde pudessem engajar-se e colaborar para a melhoria da qualidade das ações na escola. Diante das limitações encontradas no processo de participação, a autora propõe que a escola invista "na construção de relações com seus interlocutores, que permitam imprimir uma nova potencialidade ao conflito, balizadas no diálogo e na aceitação das possíveis diferenças". (p.89)

As perspectivas democratizantes colocadas pela sociedade brasileira nos anos 90 estimularam Rosa Lydia Corrêa (1991) a analisar a administração escolar através da Associação de Pais e Mestres e do Conselho de Escola de duas escolas da rede pública de ensino de Campinas/SP (uma estadual e outra municipal). Embora ambas tivessem Conselhos de Escola Deliberativos, em obediência às respectivas legislações que os instituíram, Corrêa deduz, através dos depoimentos coletados, que a forma verbal - e somente ela - servia como via de contestação das relações autoritárias que a administração das escolas mantinha com os segmentos interno e externo à unidade escolar. Assim, a aparente ausência de interesses coletivos acabava por criar uma lacuna em que se reforçavam as ações autoritárias da administração. Como uma conclusão geral do trabalho, Corrêa registra que a administração escolar está "muito mais próxima de uma performance autoritária do que democratizante". (p.114-115)

De modo similar a Rosa Lydia Corrêa, mas mencionando como referência a preocupação com a participação dos pais, presente nos textos oficiais na área de 
educação do município do Rio de Janeiro nas últimas décadas, José Gondra (1991) propôs-se a caracterizar a participação no cotidiano de uma escola pública de primeiro grau através das instâncias institucionalizadas para tal: Círculo de Pais e Professores, Conselhos Escola-Comunidade e de gestão colegiada, eleições para diretores das escolas, e discussão do Regimento Geral das escolas. Várias contradições entre o teor democratizante das propostas e as práticas autoritárias nos processos desencadeados tanto pela escola quanto pela Secretaria de Educação são anotados por Gondra, entre elas as interrupções e os adiamentos das iniciativas da Secretaria, sem consulta ou sequer justificativa, à comunidade escolar, a falta de autonomia política e financeira das unidades escolares, bem como a pouca participação dos pais no cotidiano da escola, que, entre outros fatores, contribuíam para a descrença, para o desinteresse e para o conformismo manifestados por eles.

Uma proposta de gestão colegiada em uma escola pública estadual localizada na região metropolitana de Fortaleza/CE - que, dizia-se, era administrada de uma forma "diferente" - foi analisada por Josete Sales (1993), com o intuito de verificar de que maneira concretizava o projeto de democratização da educação. A experiência evidenciou práticas clientelistas, populistas e corporativistas no interior da unidade escolar que uniam as diferentes entidades às quais cabia a responsabilidade pela gestão participativa: a Associação de Pais, Mestres e Comunitários, o Conselho de Escola e o Grêmio Estudantil. Assim, sob o manto da solidariedade daquelas entidades entre si, não havia renovação dos mandatos de seus integrantes, com a justificativa dos anos de experiência no cargo e da prestação de serviços à comunidade. Os princípios democráticos que fundamentam uma gestão colegiada também eram deixados em segundo plano pela sedução que exerciam os traços de personalidade da diretora da 
escola nos integrantes da Associação, do Conselho e do Grêmio. Diante desse quadro, a autora chega à conclusão de que não havia uma forma "diferente" de administração na escola, mas que havia, sim, uma compreensão equivocada do conceito de democracia, por parte dos pais, alunos, professores e funcionários da escola em questão.

A eleição para diretores, enquanto mecanismo particular da gestão democrática da escola pública, foi analisada por Luiz Fernandes Dourado (1990), Celina Calaça (1993), Ana Angélica Rodrigues de Oliveira (1994), Léa Reis (1995) e Ivan Luiz Novaes (1996), com o objetivo de verificar os limites e as possibilidades que colocava para a participação dos diversos segmentos na administração da unidade educacional.

Luiz Fernandes Dourado (1990) estuda o processo (dito) de democratização das escolas municipais de Goiânia, através da discussão das modalidades de gestão das escolas na década de 80: a livre indicação de diretores pelos poderes do Estado; a indicação de diretores por lista tríplice e concurso; e a eleição direta. Assim, mostra que a livre indicação dos diretores (forma de gestão das escolas municipais de Goiânia até meados da década de 80) configura-se como a modalidade que mais se coaduna com as formas usuais do clientelismo. Por outro lado, revela que o concurso público para o cargo de diretor - defendido por setores da comunidade científica - compreende a administração apenas na sua dimensão técnica, desprezando sua dimensão política. Revela, ainda, que o recurso à lista tríplice não assegura completamente à comunidade escolar a condução do processo, uma vez que a decisão final cabe ao poder executivo. Defende, portanto, a eleição direta como um instrumento imprescindível para a democratização da educação, que, no entanto, deve ser associado a outros instrumentos, com o objetivo de restabelecer o exercício coletivo da gestão. 
Confirmando Dourado, Celina Calaça (1993) observa que a adoção da modalidade da eleição direta para diretor de escola, como medida isolada, não havia contribuído para a instauração de uma prática administrativa democrática em uma escola da rede municipal de ensino de Goiânia. Nesse caso, nem mesmo a experiência de quase dez anos de eleição direta para diretor conseguira alterar a dinâmica das relações internas da unidade escolar. Em primeiro lugar, não havia um projeto institucional que correspondesse aos interesses da população local. No que se refere à organização administrativa, uma racionalidade tecnocrática orientava as relações sociais no cotidiano da escola, distribuindo as atividades segundo uma hierarquização de funções. Dentro dessa estrutura, os pais não apareciam nem sob a dimensão simbólica. Além disso, não existiam na escola canais institucionais que viabilizassem a participação dos diferentes segmentos. Desse modo, a autora chega à conclusão de que, embora a eleição direta represente um avanço para o processo de democratização, ela deve inserir-se em um projeto de maior alcance para que se possa assegurar uma gestão democrática da escola pública.

Ana Angélica Rodrigues de Oliveira (1994) toma a eleição para diretores como objeto de estudo para verificar as potencialidades e as limitações que representava para o envolvimento e a participação dos diferentes segmentos na gestão da unidade escolar. Realizando pesquisa em escolas estaduais do município de Volta Redonda/RJ, Oliveira concluiu, tal como Dourado e Calaça, que apenas a eleição não assegura a prática democrática, uma vez que não é acompanhada de medidas que garantam a efetiva participação da comunidade escolar na gestão da escola. Nesse sentido, a autora observa que a centralização dos recursos administrativos e financeiros efetuada pela Secretaria 
de Educação acabava por estender seus efeitos no âmbito pedagógico, caracterizando o que Oliveira denomina de "autonomia do abandono". Assim, o não repasse dos recursos às escolas sintetizava a política do abandono, que era compensada pela autonomia concedida à comunidade escolar para suprir a carência dos recursos.

O trabalho de Léa Reis (1995) analisa o processo de eleições de diretores na rede pública de ensino do município do Rio de Janeiro, a partir de 1987, como conseqüência da luta pela redemocratização da sociedade brasileira, para verificar as possíveis relações entre a eleição de diretores e a implantação da gestão democrática na escola pública. Considerada pelos professores como conquista da categoria, cujo mérito estaria em possibilitar a participação e a avaliação, por parte da comunidade, do trabalho desenvolvido na escola, a eleição dos diretores cria uma expectativa em torno de sua atuação, no sentido de que, ao incentivar a participação dos diferentes segmentos escolares, rompa com os limites impostos pela burocracia administrativa. No entanto, o trabalho revela que, na maioria dos casos, não é isso o que ocorre, observando-se a descontinuidade do processo de participação, que, a par desta característica, acaba por envolver os professores apenas.

Com o objetivo de analisar o processo de democratização da gestão da educação no sistema municipal de ensino de Salvador/BA, Ivan Luiz Novaes (1996) privilegia o estudo do processo de eleições diretas para diretores e vice-diretores das escolas da rede, no período de 1993 a 1995. Na vigência da lei que ampliou a participação dos segmentos da escola na eleição dos dirigentes da unidade escolar, Novaes registra a existência de um paradoxo entre o que a lei propunha e o que se observava nas escolas: se, por um lado, a legislação inovava, criando maiores possibilidades de participação e 
de controle do processo por parte dos atores sociais, por outro, a realidade mostrava uma rede de ensino como baixo grau de autonomia, permeado de relações clientelistas, e que não tinha o hábito de promover a discussão política e pedagógica. Embora reconheça a distância que separa a legislação de sua aplicabilidade, o autor não deixa de constatar avanços na direção de um processo democrático de gestão, que, segundo ele, vem se fortalecendo paulatinamente à medida que se amplia o número de pessoas envolvidas no processo.

A análise da implantação de estruturas participativas na cidade de Campinas/SP, durante a gestão municipal de 1989 a 1991, no que se refere ao processo de formação dos Conselhos Populares e dos Conselhos de Escola, foi o objeto de investigação de Pedro Ganzeli (1993). Em relação aos Conselhos de Escola, os limites na implantação dessa estrutura participativa localizavam-se naqueles trabalhadores da educação que não aceitavam qualquer mudança na hierarquia de poder da escola, mas as possibilidades remetiam à ampliação dos confrontos entre as diferentes organizações populares na luta pelo domínio dos aparelhos do Estado. Uma vez que as demandas participativas na área da educação se formaram também no âmbito interno das escolas - através das diferentes categorias nelas presentes - observou-se uma aprendizagem por parte de seus integrantes, na medida que o papel, as necessidades e as expectativas de cada categoria que vivenciava o cotidiano escolar foram postas em questão.

Do mesmo modo que Ganzeli, Maria Elsa Markus (1997) analisou uma proposta de participação de pais e mães de alunos no contexto de um projeto político-pedagógico idealizado pelo poder público municipal. Assim, o fundamento participativo, ao orientar a definição da política social do município de Rondonópolis/MT, no período de 1985 a 
1988, constituiu o suporte para a formulação do projeto político-pedagógico da Secretaria Municipal de Educação, que tinha como princípio a democratização da educação: a forma proposta para a participação de pais e mães foi o Conselho de Pais e Mães, a ser eleito em cada escola, a que deveria seguir-se uma entidade que reunisse todos os Conselhos, e, mais tarde, a Frente Popular de Educação. A par de seu grau de amplitude, a experiência mostrou suas possibilidades e suas limitações: enquanto pais e mães contribuíram para a reorganização dos conteúdos de ensino, através da incorporação de saberes críticos, e para o reordenamento dos tempos e espaços da escola, por exemplo, os condicionantes de natureza material, institucional e ideológica dificultaram sua participação, tal como constatado por Vitor Paro, em trabalho publicado em 1997.

A democratização da gestão da escola pública também foi objeto de atenção de Graziela Miranda (1998) e Maria Lucia Fortuna (1997).

Graziela Miranda (1998) preocupou-se com a democratização da escola pública como decorrência de um processo mais amplo de descentralização/democratização da educação. Portanto, o trabalho teve por objetivo investigar o impacto da adoção de medidas, tais como: a eleição de diretor, a transferência de verbas e a implantação de Conselhos nas escolas, no gerenciamento das unidades escolares, expresso em: práticas de gestão democrática, autonomia administrativa e financeira, e manutenção do prédio escolar. Desenvolvendo o trabalho em quatro estabelecimentos públicos de ensino de Salvador/BA (dois da rede estadual e dois da rede municipal), a autora chega à conclusão de que a melhoria gerencial não podia advir apenas da eleição de diretores e da implantação legal dos Conselhos, porque exigia, também, a autonomia tanto 
financeira quanto administrativa das escolas - que não existia em sua completude - em relação aos órgãos centrais da Secretaria de Educação.

Já Maria Lucia Fortuna (1997) estudou a democratização da escola pública a partir de seus condicionantes subjetivos, combinando matrizes teóricas oriundas da ciência política com os conceitos desenvolvidos pela psicanálise. Assim, buscou desvendar as articulações presentes entre os "traços identificatórios" dos sujeitos particulares e dos sujeitos coletivos. Por meio de um estudo de caso, de cunho etnográfico, realizado em uma escola pública estadual situada na periferia urbana de Niterói/RJ, Fortuna mostrou a existência de uma diferença entre o "eu" presente e o "eu" futuro, espaço no qual o sujeito constrói a sua história. Sendo portadora de incertezas, dúvidas e sofrimentos, a diferença leva o sujeito à sua superação através das relações. Se é assim da perspectiva do sujeito particular, da perspectiva do sujeito coletivo (do grupo), é a democracia que ocupa o lugar daquela diferença. Por isso, segundo a autora, a democracia precisa ser mantida como um produto inacabado, uma utopia em permanente construção, para manter o grupo enquanto grupo, porque este sobreviverá sustentado pela ilusão do ideal democrático, que nada mais é do que um desejo em permanente estado de pulsão.

Os sucessos e os fracassos de uma gestão voltada para a dinâmica comunitária em uma escola estadual recém-construída em local conhecido pelo alto índice de criminalidade na Grande São Paulo foram objeto de análise de Elisa Calil (1994), na suposição de que o funcionamento institucional influenciaria a aprendizagem de alunos provenientes das camadas de baixa renda. Na condição de diretora da unidade escolar, a autora constatou que a criação de canais institucionais de participação, ao mesmo tempo que atendiam os preceitos legais, formalizavam os passaportes da integração dos pais e da formação do 
aluno, estimulando as necessidades e os desejos da comunidade, de início, fundamentalmente, de ordem material. No entanto, Calil registrou que ainda se constituía um desafio manter a participação dos pais embora negando a distribuição de "bens" e de privilégios.

A análise de uma experiência de gestão compartilhada em uma escola pública estadual da região de Itajaí/SC, no contexto do processo de democratização da educação verificado em Santa Catarina no início dos anos 90, constituiu o estudo de Vera Lúcia Fagundes (1997). Expresso em uma nova proposta curricular a ser implantada nas escolas catarinenses, tal processo de democratização envolveu, no plano regional, diretores e especialistas das várias unidades escolares, e, no plano da própria unidade escolar, seus diferentes segmentos. No que se refere à escola estudada, a autora registra que surgiu, em muitos momentos, entre os participantes, um jogo de forças que acabou por revelar a dimensão da experiência coletiva, e que os levou a articular "o pensar e o fazer". Contraditoriamente, não deixou de ocorrer relações de exclusão, fundadas em preconceitos, e relações de dominação. No entanto, a autora conclui que o maior ganho da experiência foi a criação de um espaço de convivência, onde essas relações foram todo o tempo questionadas.

O estudo das relações gestionárias e pedagógicas em uma unidade pública de ensino na periferia de Belém/PA, na qual o envolvimento comunitário era uma opção da escola, levou Dinair Leal da Hora (1998) a conhecer "[as] artes e [os] ofícios da participação coletiva". Fundada para atendimento das famílias que se deslocavam para o novo bairro que surgia na periferia de Belém, em um prédio adequado às condições geográficas da região, organizada administrativamente com princípios democráticos, e tendo o 
desenvolvimento curricular e os conteúdos gerados pelas necessidades dos sujeitos no contexto social imediato, a escola em questão executava um trabalho, em articulação com a Associação dos Moradores do Bairro, que buscava o atendimento das expectativas da comunidade. Em decorrência dessa caracterização, a autora pôde constatar que a construção coletiva, com os avanços e os retrocessos inerentes a um processo, estava sempre presente nas ações e nas reflexões cotidianas dos sujeitos envolvidos.

No período que estamos tratando - década de 90 - grande parte dos estudos que se ocupam especificamente da democratização da gestão do sistema educacional o fazem na perspectiva da democratização da gestão no âmbito das unidades escolares, como se pôde observar ao longo das páginas precedentes. Entretanto, alguns raros estudos, já a partir do final dos anos 80 , se orientam para o processo de democratização da gestão que atinge as instâncias intermediárias e centrais do sistema educacional. Apresentamos, aqui, apenas o estudo de Ada Augusta Bezerra e Ledi Schneider por termos dado preferência, neste item, aos trabalhos que abordam o tema da participação dos pais e mães em canais institucionais nos anos 90, período em que o tema predomina na literatura acadêmica. ${ }^{14}$

Ada Augusta Bezerra (1997) avaliou a experiência de construção coletiva da Proposta

\footnotetext{
${ }^{14}$ Os dois outros trabalhos que tratam da democratização da gestão nas instâncias intermediárias e centrais do sistema educacional são o de Cleusa Couto de Oliveira (1988) e o de Antonio Elizio Pazeto (1988). Os outros trabalhos que tratam da democratização da gestão no âmbito das unidades escolares anteriores a 90 são: o de Maria Dativa de Salles Gonçalves (1980); o de Maria de Fátima Gomes de Melo (1981); o de Maria de Fátima Costa Félix (1982); o de Vitor Henrique Paro (1986); o de Belmira Bueno (1987); o de Maria de Lourdes Prais (1987); o de Rita Maria Santos (1987); o de Lúcia Barreto Rosas (1988); e o de Jair Militão da Silva (1989). (Ver Bibliografia)
} 
Curricular da rede pública municipal de Aracaju/SE, no período de 1989 a 1992, ocasião em que exercia o cargo de Secretária de Educação. Nesse contexto, abordou, no plano teórico-prático, duas questões fundamentais da administração da educação: a gestão democrática e o trabalho como princípio educativo do currículo da escola pública. O ponto nevrálgico da experiência, que simultaneamente revelou sua fragilidade e sua potencialidade, foi o fato de o grupo haver expressado em sua produção o trabalho como princípio educativo, embora numa formalização híbrida com a concepção do trabalho percebido sob relações capitalistas. Entretanto, a constatação de que a prática no âmbito da educação municipal ainda convivia com estigmas e discriminações que cercearam de forma real a participação dos estudantes, de seus pais e de lideranças comunitárias, representou, para a autora, "a maior fragilidade da experiência de Aracaju". (p.217)

O trabalho de Ledi Schneider (1997) refere-se ao processo de concretização das estratégias propostas no Plano Decenal Municipal de Educação de Teutônia/RS, na parte que prevê a integração da escola com a comunidade, e que teve a participação de pais e professores oriundos de oito comunidades escolares e da Secretaria Municipal de Educação. A metodologia adotada - a pesquisa-ação - permitiu que as reflexões, tanto diagnósticas quanto de procedimentos permanentes de investigação, contemplassem os envolvidos com informações novas, o que veio a contribuir para a aquisição de novas percepções. Como uma conclusão mais geral do trabalho, Schneider anota que as contradições e mediações que permearam as ações e as reflexões dos envolvidos não se constituíram obstáculos para a operacionalização das estratégias propostas, o que possibilitou uma maior aproximação e melhor relacionamento dos membros do grupo e o fortalecimento da idéia de comunidade presente nas escolas. 
As dissertações e teses aqui apresentadas, ao elegerem para seu objeto de estudo a participação dos pais e mães em canais institucionais no contexto da luta pela extensão dos direitos empreendida pelas camadas populares, de modo geral, não vincularam a participação literalmente a "pais e mães", antes a vinculando à "comunidade", compreendida como uma entidade coletiva que congregaria os pais e as mães dos alunos. Assim, os trabalhos acadêmicos em seu conjunto, quando não utilizam de forma não discriminada os termos 'pais' e 'comunidade', referem-se aos pais e mães de alunos ou sob a denominação de "comunidade" (ou "comunidade de pais"), ou sob a denominação de "comunidade extra-escolar" (externa à escola), ou, ainda, sob a denominação de "comunidade escolar", nesse caso junto aos professores e funcionários da escola. Apenas três exceções se registram: o trabalho de Luci Samartini (1994), que aponta o uso indiscriminado do termo e prefere utilizar a expressão 'pais e alunos' mais rigorosa do ponto de vista metodológico - , porque tem em vista investigar a possibilidade de participação destes na administração da unidade escolar; o trabalho de Miriam Bueno (1994), que questiona a aparente homogeneidade do termo 'comunidade', porque tem em vista apreender níveis diferenciados de participação das camadas populares decorrentes de suas diversas condições sócio-econômicas e culturais, determinantes de seu pertencimento a diferentes frações de classe; e o trabalho de Dener Luiz da Silva (1996), que, pretendendo esclarecer a natureza do vínculo existente entre a participação da "comunidade" e a dinâmica interna da escola através das interações sociais observadas no Conselho de Escola, chega à conclusão de que não se pode aplicar o termo 'comunidade' ao conjunto dos grupos presentes no interior daquele colegiado por causa de sua heterogeneidade. 
No que se refere à perspectiva de gênero, que poderia contribuir para uma análise mais aprofundada da participação de pais e de mães na gestão do sistema educacional, esta ficou encoberta pela perspectiva da comunidade como opção metodológica de abordagem do processo de democratização da gestão através da participação em canais institucionais; assim, nos trabalhos acadêmicos aqui arrolados, as análises realizadas, quando permitiam sobrevir a temática do gênero, o faziam, no melhor dos casos, interpretando-a simplesmente como variante da luta política que ocorre em todo processo de construção coletiva (por exemplo, Berkenbrock, 1993). A única exceção está em Miriam Bueno (1994), que procede a uma distinção de gênero - famílias chefiadas por mulheres, à diferença de outras em igual situação sócio-econômica - , para mostrar as características de sua participação na gestão da escola, prejudicada pela necessidade de realização de um duplo trabalho: o doméstico e o executado fora do lar.

\section{O termo comunidade no âmbito das determinações do poder politico}

Se, como vimos anteriormente, nos movimentos sociais e na participação em canais institucionais, a comunidade se encontra associada à ação coletiva, não é sempre nesse âmbito que o termo adquire um significado.

Dentro da perspectiva dos que acompanham a gênese do termo no campo propriamente político-ideológico, Robert Nisbet e Safira Ammann dão contribuições relevantes por associarem a valorização do termo às mudanças mais recentes que acompanharam o capitalismo como modo de produção dominante no mundo ocidental - o caso de Nisbet - 
e que deram vida a essa forma de reprodução social na política de dominação levada a efeito pelas nações capitalistas sobre os sistemas políticos sob sua influência a partir da Segunda Guerra - o caso de Ammann. Belmira Bueno também contribui para que se possa perceber o comprometimento do termo comunidade no campo políticoideológico, ao mostrar os desdobramentos da sua valorização no âmbito específico da educação brasileira, através das Associações de Pais e Mestres (APMs).

Robert Nisbet, em artigo traduzido de seu livro The Social Tradition (Nisbet, 1990), realiza reconstituição histórica, acompanhando o declínio e o ressurgimento do termo comunidade na esteira das transformações econômicas, sociais e políticas por que passou a sociedade ocidental nos últimos séculos. Nisbet assinala que a redescoberta da comunidade foi "o fato mais notável na evolução do pensamento sociológico do século XIX” (Nisbet, 1990, p.255), em contraposição à idéia do contrato como elemento legitimador das relações sociais. Assim, antes da restauração de seu prestígio, o que predominava era uma imagem racionalista da sociedade em sua versão jusnaturalista, em que a volição, o consentimento e o contrato se sobrepunham à imagem precedente de indivíduos livres por natureza. Segundo Nisbet, para a consolidação daquela imagem racionalista concorreram as duas Revoluções - Industrial e Francesa - que, ao colaborarem para a derrubada das tradições comunais do feudalismo, removeram os obstáculos ao desenvolvimento econômico e à reforma administrativa desejados pela nova classe de homens, os burgueses. No entanto, para fazer contraposição a essa imagem racionalista da sociedade, o termo comunidade ressurge no século dezenove, e é empregado por muitos pensadores para abranger "todas as formas de relacionamento caracterizadas por um grau elevado de intimidade pessoal, profundeza emocional, engajamento moral, coerção social e continuidade no tempo" e em que "o elemento 
fundamental do liame comunitário é a antítese, real ou imaginária, representada no mesmo ambiente social pelas relações não comunitárias de competição ou conflito, utilidade ou consentimento contratual.” (Nisbet, 1990, p.255-256)

Safira Ammann, em estudo no qual procura rastrear o desenvolvimento de comunidade no Brasil (Ammann, 1987), observa que a expressão foi utilizada pela Organização das Nações Unidas (ONU), após a Segunda Grande Guerra, num momento em que os Estados Unidos e a Rússia iniciam a chama Guerra Fria, na disputa da primazia política, econômica e ideológica de um mundo bipolarizado. Aplicado ao nosso país, o desenvolvimento de comunidade se associa à idéia, defendida pelos americanos, de ajudar os povos sob sua suposta influência política a alcançar um nível de vida mais sadio e economicamente produtivo, e se apresenta sob a forma de programa de assistência técnica oferecido ao governo brasileiro. Assim concebido, o desenvolvimento de comunidade requer a participação popular como elemento necessário ao processo de desenvolvimento nacional, mas, segundo a autora, "não define de modo inequívoco o conceito de participação" (Ammann, 1987, p.161). Nesse sentido, a participação foi compreendida em duas acepções antagônicas, no contexto de uma visão integrada e de uma visão fragmentada da sociedade brasileira. Na visão integrada, seja nas instâncias micro, seja nas instâncias macrossocietárias, a participação popular deveria contribuir para a construção de uma nação justa e igualitária, sem colocar em questão as estruturas econômicas, sociais e políticas da sociedade brasileira. $\mathrm{Na}$ visão fragmentada, a participação popular se definiria como "controle efetivo dos meios, fins e resultados materiais e imateriais das atividades dos indivíduos na sociedade" (Ammann, 1987, p.162), assumindo sua parte na responsabilidade social e propugnando por mudanças estruturais no país. 
No que diz respeito especificamente à educação brasileira, também se associa a valorização do termo comunidade às injunções na esfera sócio-política que tornam o termo oportuno na esfera político-ideológica. Pode-se dizer que a inspiração originária do termo comunidade se localiza na concepção de escola como fator de reconstrução social, que encontrou certa repercussão em nossos meios educacionais a partir de sua formulação primeira em John Dewey e de sua divulgação entre nós realizada por Anísio Teixeira, Fernando Azevedo e Lourenço Filho na década de 30. Desse modo, para atender ao papel da escola no projeto de reconstrução social, conjugou-se o princípio da reconstrução do aluno-indivíduo, baseada na expansão dos interesses naturais da criança, ao princípio da sua socialização, através do desenvolvimento de um trabalho cooperativo. Nesse contexto, para que a unidade escolar pudesse desempenhar a contento seu papel, como um elemento de reforço e coordenação de toda a ação educativa (Lourenço Filho, 1930), é que se criaram instituições auxiliares à escola, congregando pais e mestres. (Bueno, 1987)

De início facultativas, em 1931, as Associações de Pais e Mestres (APMs) se tornam obrigatórias quarenta anos depois, com a segunda Lei de Diretrizes e Bases da Educação Nacional de agosto de 1971 (art. 62 da Lei $n^{\circ}$ 5692/71), na esteira da retomada da polêmica entre o ensino público e o ensino privado no final da década de 50, por ocasião da elaboração da primeira Lei de Diretrizes e Bases da Educação Nacional, que,

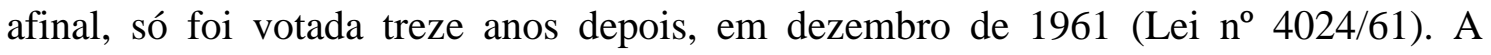
previdência do legislador de 1971 em reunir pais e mestres em uma associação, em caráter obrigatório, se explica, de acordo com Belmira Bueno, porque a estas entidades APMs - já estava sendo reservado, desde os anos 60, o papel de suplementadoras dos 
recursos que, como era previsto, faltariam à educação pública, em face dos interesses privatistas que prevaleceram com a primeira lei $^{15}$. Com a obrigatoriedade das Associações de Pais Mestres, àquela primeira idéia que concebia a unidade escolar como um elemento de reforço e coordenação de toda a ação educativa - na qual os pais estariam mais facilmente submetidos à influência do trabalho pedagógico desenvolvido na escola - veio se somar a idéia de os pais colaborarem na manutenção das condições materiais da escola.

\section{O conceito de comunidade na perspectiva dos clássicos}

O conceito de comunidade foi objeto de atenção de vários estudiosos que destacaram nele certas acepções em acordo com seu approach teórico. Relaciono, aqui, as formulações de Ferdinand Tönnies, Hans Freyer e Max Weber que são consideradas clássicas sobre o assunto e, em acréscimo, apresento o ponto de vista de Louis Wirth que supera a circularidade bipolar entre comunidade e sociedade das contribuições clássicas e é, nesse sentido, inovador.

Para Ferdinand Tönnies (1973), comunidade representa uma associação, determinada por relações reciprocamente positivas entre seus membros e permeada por uma vida real e orgânica. Expressão de um pensamento que se coloca nos marcos de uma sociologia sistemática, a comunidade para Tönnies se contrapõe à sociedade enquanto uma associação compreendida como uma representação virtual e mecânica: "numa certa medida, pode-se compreender a comunidade como um organismo vivo, e a sociedade

\footnotetext{
${ }^{15}$ Apoiado no princípio da liberdade de ensino, o legislador de 1961 reivindicara recursos ao Estado em favor da família, no intuito de beneficiar não tanto o ensino público mas antes o ensino privado.
} 
como um agregado mecânico e artificial" (Tönnies, 1973, p.98). Para ele, a comunidade evolui de um estado primitivo e natural para um estado em que as relações entre os diferentes indivíduos se tornam necessariamente vinculadas: "a unidade e a possibilidade de uma comunidade das vontades humanas se apresentam, em primeiro lugar e de maneira mais imediata, nos laços de sangue; em segundo lugar, na aproximação espacial e, finalmente, para os homens, na aproximação espiritual" (Tönnies, 1973, p.104). Na concepção do autor, comunidade e sociedade são entidades típico-ideais que procuram responder à natureza diversa das associações humanas.

Assumindo uma orientação bipolarizada mas não estanque no que se refere à relação entre os homens, Hans Freyer (1973) concebe a comunidade como uma lei determinada da vida social que carrega em si uma dinâmica específica: "a comunidade só pode ser compreendida como um membro da série temporal concreta das formas sociais fundamentais, isto é, como uma estrutura determinada, sustentada por uma constelação específica das energias humanas" (Freyer, 1973, p.132). Como tipo condicionado historicamente, a comunidade representa uma época em que não há dominação de espécie alguma, em que o patrimônio cultural, tanto material quanto espiritual, existe como propriedade de cada um dos diversos membros do grupo. Nesse contexto, a sociedade aparece como resultado de uma situação de domínio, em que um grupo monopoliza para si partes do patrimônio cultural, mas que não deixa de se estruturar como um conjunto orgânico expressando uma cultura superior. Regulada por uma lei estrutural distinta da que regulava a comunidade, a sociedade carrega em si o germe da modificação histórica. 
Para Max Weber (1973), a diferença entre comunidade e sociedade se baseia na natureza dos laços de sociabilidade: "chamamos comunidade a uma relação social quando a atitude na ação social - no caso particular, em termo médio ou no tipo puro inspira-se no sentimento subjetivo (afetivo ou tradicional) dos partícipes da constituição de um todo; chamamos sociedade a uma relação social quando a atitude na ação social inspira-se numa compensação de interesses por motivos racionais (de fins ou de valores) ou também numa união de interesses com idêntica motivação" (Weber, 1973, p.140). Para ele, a comunidade como "tipo" de estrutura de socialização está melhor representada pela família, mas reconhece que a imensa maioria das relações sociais participam tanto da "comunidade" quanto da "sociedade". Atento às contribuições empíricas da sociologia como disciplina, Weber utilizou-se da caracterização das estruturas comunitárias e societárias para fazer dos dois conceitos recursos que pudessem guiar a observação, a descrição e a interpretação das ações e das relações sociais.

A exemplo de Weber, Louis Wirth (1973) também orienta sua perspectiva para a análise de segmentos concretos da vida social. Nesse enfoque, Wirth relativiza os conceitos de "sociedade" e de "comunidade", afirmando que estas "não são duas espécies de vida grupal diferentes, porém dois aspectos de toda vida grupal humana" (Wirth, 1973, p.85). Para ele, toda comunidade tem a dimensão do viver junto e do participar de uma vida em comum, cujo sentido sofre mudanças na medida em que mudam os símbolos coletivos, as leis, os costumes e a linguagem. $\mathrm{O}$ autor observa que a transição para um tipo de organização social marcada por rápido desenvolvimento tecnológico, mobilidade e controle social formal trouxe novos problemas para a comunidade que só serão superados se os homens tiverem disposição de agir coletivamente diante de interesses 
divergentes, criando novas bases para a integração social. No que diz respeito às diferenças conceituais entre comunidade e sociedade, Wirth defende a correlação e a reciprocidade que os dois conceitos mantêm entre si, referindo-se às características complementares que grupos sociais, presos a laços territoriais, físicos, ecológicos e sócio-psicológicos, apresentam para distinguir comunidade e sociedade.

Sob diferentes pontos de vista, o conceito de comunidade, em contraposição ao conceito de sociedade, tencionou referir-se a um modo específico de convívio social humano. Na tentativa de ordenar as relações sociais entre pessoas ou grupos de pessoas, os teóricos aqui relacionados formularam diferentes versões para nomear/identificar formas de associação humana nas suas características de estrutura, funcionamento ou orientação das ações.

\section{A "implosão" do conceito de comunidade em perspectivas mais recentes no campo da educação}

$\mathrm{Na}$ introdução ao capítulo que trata das distinções e contrastes conceituais básicos entre comunidade e sociedade, Florestan Fernandes (1973) alerta o leitor para a primazia que o foco teórico privilegiado pelo investigador tem na importância que ele dá a aspectos "comunitários" ou "societários" da vida social. Contrapondo-se ao senso comum que pretende descobrir as dimensões comunitárias e societárias na natureza mesma dessas unidades - comunidade e sociedade - , o autor esclarece que "em função da unidade das formas existenciais inerentes às várias modalidades de organização da vida social, tais aspectos objetivam-se simultaneamente e são inseparáveis in concreto.” (Fernandes, 1973, p.58). Isto significa dizer que é apenas a observação dos vários níveis em que os 
homens organizam a vida em sociedade que pode - e deve - orientar a perspectiva do pesquisador, na medida em que este quer descobrir dimensões "comunitárias" e dimensões "societárias" do convívio social humano.

Parece ter sido esta a direção seguida por alguns pesquisadores na área da educação, que se recusaram a reconhecer a priori na "comunidade escolar" uma entidade homogênea, que englobava alunos, pais de alunos, professores e funcionários - no seu significado amplo - , ou que se restringia apenas àqueles que se utilizam dos serviços oferecidos pela escola - no seu significado restrito.

Muito embora a utilização do conceito de comunidade escolar em seu sentido amplo possa render, no campo político, extensos benefícios - ao ampliar o espectro dos segmentos que devem participar da gestão das escolas - , seu potencial heurístico na análise das relações sociais que ocorrem no âmbito da escola fica prejudicado, pois, conforme mostraram alguns estudiosos, a "comunidade" é um termo cujo conteúdo precisa ser especificado.

Inah Passos, Marília Carvalho e Zoraide Faustinoni da Silva (1988), em trabalho no qual relatam uma experiência de gestão colegiada em escola pública na periferia de São Paulo, assinalavam que a "comunidade escolar" era um termo usual na linguagem dos profissionais de educação, dos documentos oficiais e dos militantes dos movimentos populares. Observavam, ainda, que sua utilização remetia a uma visão idílica da população usuária, no interior da qual não havia conflitos, nem contradições. O contato das autoras com uma unidade escolar de ensino público, no entanto, lhes permitiu perceber uma escola “dividida em inúmeros setores hierarquizados e com interesses 
corporativos diferenciados (funcionários, professores, direção, etc.) [e] perpassada por posições políticas e educacionais diferentes" (Passos et al., 1988, p.86). Permitiu-lhes, ainda, constatar que as diferentes formas de ser pai, mãe ou aluno são determinadas pela condição social, resultando em "diferentes formas de ver a escola, o que gera conflitos e contradições”. (Passos et al., 1988, p.86) Em síntese, as autoras desmascaram o chamado "mito da comunidade", ao descaracterizar sua pretensa unidade e homogeneidade revelando uma multiplicidade de posições tanto no interior da escola quanto na população.

Também Sérgio Avancine (1990), em estudo no qual registra a participação de mães na gestão de escola pública na periferia de São Paulo, afirma ser uma "idealização romântica" conceber a priori o grupo de moradores de um bairro da periferia como sendo uma comunidade. Para ele, isso é inverossímil a partir do momento em que a cidade de São Paulo está inserida em uma formação do tipo capitalista, dominada pelas relações extralocais geradas pela produção e pela circulação da mercadoria. Para ratificar sua posição, Avancine lembra as diferenças existentes entre moradores, por exemplo, quanto à faixa de renda ou inserção no mercado de trabalho, quanto a condições de moradia, ou ainda quanto à consciência e visão de mundo. Anota, a esse respeito, junto à população usuária da escola, uma tendência ao predomínio do projeto individual sobre qualquer proposta coletivizadora, como resultado do nosso modo de organização social, o que, segundo o autor, coloca uma série de desafios à possibilidade de intervenção popular na escola.

No âmbito das relações entre a unidade escolar e a população, Marília Carvalho (1991), a partir do estudo de uma escola estadual paulista, relatou as alterações que seu projeto 
inicial sofreu à medida que avançava seu trabalho de campo. Naquele momento, então, ela observava que não havia nem homogeneidade interna nem limites bem definidos naquilo que vinha chamando de escola, e que, em conseqüência, seria preciso proceder a toda uma reconstrução do seu conceito. A par da extrema fragmentação interna da instituição, ela ainda percebeu que as fronteiras entre o que chamava de escola e o que chamava de comunidade não eram estáticas, nem linearmente estabelecidas. Compreendeu, então, que cada unidade escolar é "uma trama complexa de relações sociais, onde são dinâmicas as continuidades e rupturas entre o que está dentro da escola e o que está fora" e que a consistência interna da escola é resultado de um processo, e não um pressuposto. (Carvalho, 1991, p.6)

Permanecendo no âmbito das relações entre a escola e a população, também Ruth Mercado reafirma as diferenças internas existentes naquilo que a escola entende como sendo "a comunidade de pais de alunos" ao alertar para o fato de que "a escola não se relaciona com indivíduos homogeneamente constituídos como 'pais', mas sim vinculados social, econômica e politicamente a distintos interesses que se movem no âmbito local, por sua vez ligados a outros mais amplos.” (Mercado, 1983, p.49)

Por sua vez, Marília Spósito, ao refletir sobre a participação popular na escola, não deixa de observar que também aí estão presentes determinações político-ideológicas, denunciando que as concepções que fundamentam o apelo à participação fazem referência a uma comunidade que é sempre restrita:

"a 'comunidade' é apenas a parcela que freqüenta a escola, em geral os mais afinados com as orientações prevalecentes na direção da unidade. O restante do bairro - por estranha coincidência, os mais pobres ou a população moradora das favelas - não constitui a comunidade, continuamente filtrada e reduzida". (Spósito, 1989, p.64) 
A inadequação do conceito de comunidade sem especificação de seu conteúdo para analisar as relações sociais que se estabelecem na esfera da unidade escolar vem reiterar, agora especificamente na área da educação, a concepção dos movimentos sociais enquanto ação coletiva caracterizada como um campo de orientações e de reconhecimento. Nesse sentido, a fragmentação do conceito de comunidade, ao não permitir que esta seja associada incondicionalmente aos fenômenos coletivos relacionados à educação, reforça a afirmação de Melucci, para quem um movimento social, enquanto expressão da unidade e da homogeneidade como que os atores coletivos se apresentam na cena pública, é "sempre resultado de processos sociais que tornam possível, eventualmente, a formação de um sujeito coletivo". (Melucci, 1997a, p. 13, meu grifo) Em decorrência, o fato de os movimentos sociais exibirem uma unidade de ação, no plano do que é visível, não pode escamotear a circunstância de que, no plano do que não é visível - isto é, em um momento anterior à projeção pública - eles apresentam uma multiplicidade de elementos - diversas orientações da ação, diversas estruturas de relações, diversos níveis da realidade social - que caracterizam uma participação díspar e heterogênea.

Assim, no que diz respeito à participação dos pais e mães de alunos, enquanto manifestação de caráter coletivo referida à educação, pode-se compreendê-la como um processo no qual há produção de significados que podem (ou não) concorrer para a elaboração de um quadro cognitivo comum e para a constituição de um sistema de relações que vincula os atores. 
O que vou procurar mostrar no próximo capítulo - através de um estudo de caso - é que no plano em que a participação dos pais e mães de alunos aparece enquanto manifestação díspar e heterogênea, observam-se práticas diferenciadas que caracterizam a participação como fragmentada, por referência às formas mais conhecidas de participação, a participação em ações coletivas ou em canais institucionais. 


\title{
Capítulo 3
}

\section{A particípação dos pais e mães das camadas populares na escola pública fundamental - um estudo de caso}

\begin{abstract}
A primeira aproximação com a Escola Estadual Municipalizada Altino Malafaia ${ }^{16}$ ocorreu em fins de junho de 1999. Essa era uma das escolas públicas de ensino fundamental do Estado do Rio de Janeiro que havia sido reconhecida através de um Prêmio, entre mais de mil e quinhentas em todo o país, como uma das unidades escolares em que havia uma gestão competente e participativa, segundo notícia do jornal 'Extra', jornal de grande circulação no estado ${ }^{17}$.
\end{abstract}

Após um primeiro contato com a Secretaria Municipal de Educação a que estava subordinada administrativamente a escola, fui apresentada à diretora, a quem informei meu interesse em desenvolver um trabalho naquela escola por ter tido conhecimento de que ali teriam lugar experiências bem sucedidas de gestão escolar. Na ocasião, Neide, a diretora, levou-me à escola, e me fez um breve relato das atividades que a Altino Malafaia realizava, mostrando-me o documento que havia sido submetido aos sucessivos Comitês do Prêmio, onde estavam registradas em relatórios e fotografias as atividades que a escola desenvolvia. Ao lhe comunicar a natureza do meu trabalho, que requeria, para a consecução de seus objetivos, conhecer melhor a escola, freqüentando com regularidade as suas dependências e conversando com o seu pessoal, Neide deixou

\footnotetext{
${ }^{16}$ Para preservar o sigilo das informações, dei nomes fictícios à escola e às pessoas mencionadas neste estudo de caso.

${ }^{17}$ O Prêmio Nacional de Referência em Gestão Escolar foi instituído em 1998, em promoção conjunta da Unesco, do Consed (Conselho Nacional de Secretários de Educação) e da Undime (União Nacional dos Dirigentes Municipais de Educação), para estimular e referendar a busca da excelência em gestão e desenvolver uma sistemática de avaliação dos modelos de gerenciamento das escolas públicas fundamentais.
} 
claro que não se opunha, mas solicitou que eu expusesse, por escrito, a finalidade de minha permanência na Altino Malafaia para fins de justificativa junto à Secretaria Municipal de Educação.

Em correspondência a seu Plano de Ação para o ano de 1998, que tinha como um de seus objetivos específicos a execução de atividades para a integração da escola na comunidade, a Altino Malafaia registrava - e mostrava através de fotos - no documento encaminhado aos Comitês do Prêmio as ações, as campanhas e as palestras realizadas na área da saúde, que, com a participação dos pais e das mães, visava contribuir para as boas condições físicas e mentais dos alunos. Com o mesmo propósito, também incentivava a interação entre seus professores, funcionários, alunos e entre estes e a comunidade extra-escolar, através, por exemplo, de festas, eventos de confraternização, torneios e exposições, visando contribuir para a socialização, e, ainda, para a elevação da auto-estima de todos.

Apesar destes aspectos positivos no que se refere à gestão escolar, observei que não havia uma participação institucionalizada de pais e mães como parte de um processo mais amplo de participação de todos os segmentos da escola na tomada de decisões ${ }^{18}$. Desse modo, nessa unidade escolar, não se encontrava plenamente desenvolvida uma gestão democrática da educação, tendo em vista que o caráter público da atividade educativa mantida pelo Estado supõe a interferência regular e sistemática - e não apenas

\footnotetext{
${ }^{18} \mathrm{O}$ que havia na escola era uma Associação Escola-Comunidade, criada com a finalidade exclusiva de ser a Unidade Executora do Programa de Manutenção e Desenvolvimento do Ensino Fundamental, que repassa, diretamente, uma vez por ano, às escolas públicas daquela modalidade de ensino, dinheiro para custeio e manutenção de suas atividades. Por sua finalidade, dessa associação não se podia esperar a tarefa de democratizar efetivamente a gestão da unidade escolar.
} 
esporádica e assistemática - do segmento dos pais e mães nas decisões que afetam a escola $^{19}$.

Não obstante essa deficiência, percebi que pais e mães de alunos tinham livre acesso à escola - tanto à sua direção quanto aos seus professores - sendo alguns bastante conhecidos pelas pessoas que trabalhavam na unidade escolar devido à sua freqüente presença. Nessas ocasiões, as queixas e as reclamações que os pais e as mães faziam manifesta ou veladamente, presenciadas por mim ou apenas ditas a mim - revelaram ser uma forma de participação não registrada habitualmente nos estudos sobre gestão da educação.

Portanto, embora não houvesse sido estruturada - seja por iniciativa da direção da escola, seja por mobilização dos próprios pais e mães de alunos - uma forma de participação mais regular e sistemática deste último segmento no que diz respeito aos assuntos afetos à unidade escolar, as observações, as queixas e as reclamações constituíam diferentes manifestações de uma mesma reivindicação, a reivindicação de um direito, que expressava as exigências que pais e mães de alunos faziam em relação à vida escolar de seus filhos. Desse modo, a par e para além da participação em canais institucionais, registrava-se outra forma de participação, mais sutil e menos visível que esta última, fragmentada por referência às formas mais conhecidas de participação, a participação em ações coletivas ou em canais institucionais - que se tornava, então, uma questão que precisava ser investigada. Privilegiando esta questão para análise, abandonei outras que poderiam revelar algum aspecto inovador em proveito de uma

\footnotetext{
${ }^{19}$ De acordo com Norberto Bobbio, a ampliação do processo de democratização compreende, em nossos dias, a inclusão da esfera das relações sociais, onde o indivíduo é considerado em seus papéis específicos, entre os quais o de usuário de serviços públicos. (Bobbio, 1997)
} 
gestão democrática da unidade escolar.

Antes, porém, de justificar a escolha do modo de abordagem do objeto de estudo, apresentarei o município e o bairro em que a escola se localiza, levando em conta seus aspectos sócio-econômicos e educacionais, para melhor contextualizá-la.

\section{O município, obairro e a escola}

O município de Itaguaí está a cerca de $53 \mathrm{~km}$ da região metropolitana do Rio de Janeiro, constituído por três distritos: Itaguaí (sede), Ibituporanga e Coroa Grande, sob a área de influência do Porto de Sepetiba, que se localiza no próprio município.

No século XIX, por ser ponto de passagem dos viajantes das províncias de São Paulo e de Minas Gerais, a então Vila de São Francisco Xavier de Itaguaí desfrutou de ativa vida comercial, com a exportação, em grande escala, de açúcar, aguardente, café, cereais e farinha. Com o declínio econômico decorrente da perda da mão-de-obra escrava no final do século, Itaguaí só recuperou seu antigo prestígio após várias décadas, beneficiando-se de uma série de fatores, entre os quais a construção da Estação Ferroviária, a passagem da antiga estrada Rio-São Paulo por seu território, a instalação

de indústria têxtil em um de seus distritos e as obras de saneamento da baixada fluminense, o que permitiu o aproveitamento econômico de grandes áreas da região.

Hoje, suas principais atividades econômicas são o comércio (atacadista e varejista), a construção civil e, na indústria de transformação, o seu ramo metalúrgico, representado 
pela NUCLEP (Nuclebrás Equipamentos Pesados S.A.), produtora de equipamentos para usinas nucleares.

\subsection{Aspectos demográfícos, sócio-econômicos e de infra- estrutura do município}

De acordo com o Instituto Brasileiro de Geografia e Estatística - IBGE, em contagem de população realizada no ano de 1996, residem em Itaguaí cerca de 70 mil pessoas. Entre 1991 e 1996, o município apresentou uma das mais altas taxas médias geométricas de crescimento anual (TMGCA): 2,75\%, em contraposição aos $0,76 \%$ da região metropolitana do Rio de Janeiro, e aos 0,92\% do Estado do Rio. Esta elevada taxa ajuda a explicar por que se registra uma proporção bastante expressiva de crianças, adolescentes e jovens de menos de 19 anos na população total do município já em 1996: 40,67\% (Anuário Estatístico do Estado do Rio de Janeiro, 1998).

Quanto aos indicadores econômicos, os dados do censo de 1991 mostram que a renda familiar per capita média é menos de um salário mínimo (Atlas do Desenvolvimento Humano no Brasil, 1998), e ainda que, entre 100 chefes de domicílios que possuem renda até um salário mínimo, quase a metade, 48, tem filhos menores de 14 anos, portanto, dentro da faixa de idade correspondente à escolaridade obrigatória (Dimensões das carências sociais, 1996).

No que se refere à infra-estrutura do município, representada pelas condições de adequação dos domicílios, os dados do censo de 1991 indicam que, enquanto $72 \%$ das residências eram abastecidas com água, apenas $31 \%$ delas tinham esgoto sanitário ligado à rede geral ou eram detentores de fossa séptica, e somente $27 \%$ dos domicílios se beneficiavam da coleta de lixo (Rio de Janeiro, Plano Diretor de Turismo, 1999). 


\subsection{Aspectos educacionais do município}

Considerando-se as informações oriundas do censo de 1991, em Itaguaí, de cada 100 crianças entre 7 e 14 anos, 17 não freqüentavam escola, e 64 em cada 100 crianças na faixa etária de 10 a 14 anos apresentavam atraso escolar (defasagem série-idade) de mais de um ano (Atlas do Desenvolvimento Humano no Brasil, 1998).

Em relação às pessoas de 15 anos e mais que não sabiam ler e escrever um bilhete simples, estas somavam 16 em cada grupo de 100 no município (Atlas do Desenvolvimento Humano no Brasil, 1998), sendo que esta proporção subia para 60 em cada 100 nos domicílios chefiados por homens ou mulheres com rendimento igual ou inferior a um salário mínimo (Dimensões das carências sociais, 1996).

Em 1997, a taxa de aprovação do ensino fundamental no município era de 57\%, a mais baixa em toda a região metropolitana do Rio de Janeiro e uma das mais baixas em todo o Estado (Anuário Estatístico do Estado do Rio de Janeiro, 1998).

Em que pese a melhoria dos indicadores educacionais observada ao longo das últimas décadas no país como um todo, que Itaguaí também acompanha (Atlas do Desenvolvimento Humano no Brasil, 1998), não se pode considerar satisfatória a situação educacional do município, exemplificada pelos dados acima indicados.

Diante desse quadro, nos últimos anos, a administração municipal vem ampliando sua atuação no campo educacional, para dirimir as dificuldades apresentadas nesse setor. Em 1997, o recém-empossado governo municipal implantou o Projeto Educação de 
Jovens e Adultos (EJA) em oito escolas da rede, denominadas pólos, com o propósito de alfabetizar e de fornecer estudos correspondentes à primeira e à segunda séries do ensino fundamental àqueles que já haviam ultrapassado a idade própria para cursá-los. Iniciado no ano de 1997, em 2000 o EJA atendia a cerca de três mil alunos, da Alfabetização à $8^{\mathrm{a}}$ série, em vinte e dois pólos ${ }^{20}$.

Ainda em 1997, outro projeto de investimento em educação foi realizado pelo governo municipal com o objetivo de propiciar melhoria da qualidade de vida do aluno, de sua família e dos usuários potenciais da escola: o FISE - Projeto Final de Semana do Escolar. Com o FISE, os usuários efetivos e potenciais da escola podem desenvolver, na própria unidade escolar, aos sábados e aos domingos, atividades relacionadas à saúde, à educação, e ao lazer, podendo, também, ali, fazer refeições. Há, também, atendimento médico e dentário e, uma vez por mês, profissionais realizam corte de cabelo para os que assim desejarem.

Outro aspecto que mereceu atenção do poder público municipal foi a merenda escolar. Além da regularidade, buscou-se oferecer alimentação de boa qualidade, para o que foi concebido o Projeto Horta Escolar, em parceira com a Secretaria Municipal de Agricultura e Meio Ambiente e com a EMATER, empresa pública de assistência técnica rural. Conjugado com o objetivo de contribuir para o cardápio da merenda escolar, o Projeto Horta Escolar visa, ainda, ensinar às crianças a importância de se cultivar alimentos sem a utilização de agrotóxicos.

\footnotetext{
${ }^{20}$ Esta informação e as que se seguem me foram fornecidas por funcionárias graduadas da Secretaria Municipal de Educação de Itaguaí.
} 
Em 1999, foi implementado um subproduto proveniente desta experiência, o Projeto Alimentação Alternativa, direcionado para as mães dos alunos. Sua proposta consiste em promover uma reeducação alimentar, com a introdução de novos hábitos, mediante o aproveitamento não convencional de verduras, legumes e frutas.

Desde que essa última administração assumiu o governo municipal, os estudantes das escolas públicas de sua esfera de competência vêm recebendo o chamado kit escolar, composto de uniforme completo, agasalho, meia, tênis e mochila. Os estudantes recebem, ainda, todo o material escolar necessário: caderno, lápis, borracha, apontador, régua, tesoura, etc.

Como investimento complementar no campo da educação, a atual administração decidiu manter o benefício do passe escolar, através de acordo com as empresas de ônibus do município. O passe atende não só a alunos, mas também a servidores das escolas públicas municipais, que necessitam dos transportes coletivos tanto para estudar quanto para trabalhar.

Hoje, a rede municipal de ensino de Itaguaí conta com 35 unidades de ensino fundamental, incluindo dois anexos que funcionam em igrejas; nove creches de educação infantil; e uma unidade de ensino médio, com cerca de quinhentos alunos.

\subsection{O bairro}

Localizado próximo ao centro de Itaguaí, o bairro onde está situada a Escola Estadual Municipalizada Altino Malafaia teve sua formação oriunda de dois processos similares: a migração de pessoas expulsas de fazendas da região, onde trabalhavam como colonos; 
e a migração de pessoas que foram progressivamente se deslocando de seus antigos locais de moradia na região metropolitana do Rio de Janeiro, em decorrência da valorização comercial dos terrenos, para outros locais mais afastados e menos valorizados.

Ocupando a chamada periferia dos grandes centros urbanos, a população encontrou áreas não dotadas de infra-estrutura, que, embora tenham sido beneficiadas por algum tipo de melhoramento ou de serviço ao longo dos anos, permanecem até hoje como um local de carências: grande parte das ruas não é asfaltada; a coleta de lixo é feita de modo irregular; o único posto de saúde atende em condições precárias, com presença inconstante de médicos; há falta de áreas de lazer para crianças, adolescentes e jovens; não existem escolas de ensino médio, dificultando o prosseguimento dos estudos após o ensino fundamental, etc.

Um dos problemas mais graves diz respeito às más condições de saneamento evidenciadas pela falta de esgoto sanitário adequado nos domicílios. Em todas as residências do bairro, o escoamento do esgoto é feito em valas abertas pelos moradores na frente das casas ou, nos melhores casos, em manilhas que desembocam nos rios da região. De um modo ou de outro, a população do bairro está sujeita a contrair doenças diversas devido à sua vulnerabilidade às contaminações.

Outro problema grave envolve a rodovia federal que atravessa longitudinalmente o bairro em direção ao litoral sul do estado do Rio, causa de acidentes com mortes por atropelamento, pelo fato de não haver passarelas ou passagens subterrâneas. 
Como em todo bairro de periferia, a atividade econômica se restringe ao escasso comércio local, exemplificada pelas poucas padarias, açougues, botecos, vendinhas, e no qual se destacam algumas lojas de material de construção e de produtos agrícolas. Registra-se, também, em toda a extensão da rodovia federal que leva à chamada Costa Verde do estado, comércio direcionado às pessoas que se dirigem para aquela localidade, representado por lojas de material de caça e pesca, de móveis de vime, de plantas, etc.

No que se refere ao fornecimento de educação pública, atualmente, o bairro dispõe de quatro unidades escolares: uma creche, que funciona como pré-escola, atendendo crianças de 2 a 5 anos; uma escola municipal, que tem turmas de $1^{\text {a }}$ a $6^{\text {a }}$ séries do ensino fundamental, e que abriga, à noite, o Projeto Educação de Jovens e Adultos (EJA); uma escola estadual municipalizada, que acolhe crianças e adolescentes desde o Jardim até à $8^{\mathrm{a}}$ série do ensino fundamental, e que também abriga, à noite, o EJA - escola objeto deste estudo; e uma escola estadual, que oferece o ensino fundamental e o ensino médio.

\subsection{A escola}

A Escola Estadual Municipalizada Altino Malafaia funciona em três turnos, e atendia, no início do ano letivo de 2000, a 1.605 alunos, assim distribuídos: 173 alunos na Educação Infantil; 998, no Ensino Fundamental; e 434, na Educação de Jovens e Adultos. Os alunos, no período diurno, são distribuídos em turmas correspondentes às etapas iniciais da vida escolar e às diversas séries do ensino fundamental, havendo, no entanto, duas turmas de Aceleração da Aprendizagem, cujos alunos, com discreta defasagem série-idade, são preparados para, posteriormente, ocupar as séries correspondentes à idade deles. No período noturno, os alunos do Projeto Educação de 
Jovens e Adultos são distribuídos em turmas correspondentes à etapa de alfabetização e às diferentes séries do ensino fundamental, do seguinte modo: Etapa I ( $1^{\mathrm{a}}$ e $2^{\mathrm{a}}$ séries); Etapa II ( $3^{\mathrm{a}}$ e $4^{\mathrm{a}}$ séries); Etapa III ( $5^{\mathrm{a}}$ e $6^{\mathrm{a}}$ séries $)$; e, finalmente, Etapa IV ( $7^{\mathrm{a}}$ e $8^{\mathrm{a}}$ séries).

Em 2000, trabalhavam na Altino Malafaia 84 servidores: 55 em função docente, e 29 em funções de apoio - na secretaria e como inspetores, zeladores, serventes e merendeiras. Além da Direção, composta por Diretora e Diretora-Adjunta, atuavam na escola, ainda, uma Orientadora Educacional e uma Coordenadora Pedagógica. Segundo informações concedidas pela diretora, todos os servidores haviam prestado concurso e eram funcionários efetivos, o que concorria para a estabilização do quadro funcional na unidade escolar.

A Altino Malafaia faz parte de um grupo de escolas estaduais que foram municipalizadas em 1988, mediante acordo entre o Governo do Estado do Rio e a Prefeitura de Itaguaí. Antes de ocupar as instalações atuais, que pertenciam a uma escola estadual inativa, a Altino Malafaia tinha outro nome e funcionava em uma pequena construção residencial próxima. Sua atual diretora está no cargo desde essa época, no que é acompanhada por alguns servidores que também desempenham suas funções desde a época da municipalização da escola ${ }^{21}$.

A escola é um dos pólos de funcionamento do projeto FISE - Projeto Final de Semana do Escolar, cujas atividades foram-se ampliando ao longo dos anos, em virtude da enorme aceitação por parte dos seus usuários efetivos e potenciais.

\footnotetext{
${ }^{21}$ No início de 2001, no segundo mandato do atual prefeito, Neide, a diretora, foi substituída no cargo de direção da escola contra a sua vontade, passando a trabalhar na Secretaria Municipal de Educação e Cultura de Itaguaí.
} 
Na Altino Malafaia, há atendimento odontológico durante a semana para os alunos da unidade escolar, com três dentistas trabalhando em esquema de revezamento.

De acordo com informações dadas pela diretora da escola, em todo início de ano letivo, a previsão de matrículas é ultrapassada, uma vez que é grande a demanda, devido ao fato de a unidade escolar gozar de boa reputação no município e ao fato de ser a única, no bairro, que está localizada no lado esquerdo da rodovia federal (sentido centro do Rio-litoral sul do Estado) ${ }^{22}$, o que é conveniente e tranquilizador para as mães cujos filhos não têm de atravessar a via de tráfego intenso.

Como registrei no início deste capítulo, pude perceber que os pais e as mães tinham livre acesso às dependências da Altino Malafaia, tanto à sua direção quanto aos seus professores. Este fato pode ter uma explicação em um padrão de relacionamento estabelecido por Neide, a diretora, à frente do estabelecimento escolar desde o ano de 1985, quando este ainda ocupava as instalações de uma construção residencial: os quinze anos como dirigente da instituição certamente lhe deram um conhecimento mais aprofundado dos moradores do bairro, contribuindo para uma relação de confiança de Neide em relação aos pais e mães, mas que, em uma via de mão dupla, se foi, também, constituindo dos pais e mães em relação à Neide.

\section{A participação dos pais e mães de atunos}

\subsection{A coleta das informações}

\footnotetext{
${ }^{22}$ No bairro, a outra escola municipal e a escola estadual estão, ambas, situadas do lado direito da rodovia federal.
} 
O estudo da participação dos pais e mães de alunos requer o emprego de técnicas qualitativas de análise uma vez que se busca apreender as várias dimensões do fenômeno em questão. Nesse sentido, o contexto em que a participação ocorre é elemento importante para que se conheça as relações que este particular fenômeno estabelece com uma totalidade maior que, em certa medida, o determina. (Ezpeleta e Rockwell, 1989) Do mesmo modo, compreende-se que entre as várias dimensões desse objeto - a participação de pais e mães - se incluem diferentes perspectivas (Lüdke e André, 1986) que concorrem para que o leitor possa compor um quadro mais completo do fenômeno, "utilizando as particularidades das experiências sociais dos indivíduos enquanto reveladores da cultura tal como é vivida." (Michelat, 1987)

Em face destas características que envolvem a participação dos pais e mães de alunos, optou-se por estudá-la sob a forma de um estudo de caso, apoiada em um trabalho de campo de natureza etnográfica.

Assim, o estudo da participação dos pais e mães de alunos no âmbito de uma unidade escolar proporcionará ao leitor a oportunidade de examinar a experiência vicária do caso/fenômeno em estudo com base em suas próprias experiências pessoais.(Stake, 1983)

O tempo de permanência na Escola Estadual Municipalizada Altino Malafaia estendeuse de junho de 1999 a outubro de 2000, com uma freqüência mais acentuada no primeiro ano. Durante este período observou-se o dia-a-dia da escola, em seus três turnos de funcionamento, com a presença da pesquisadora em aulas, em reuniões de professores com pais e mães, em conselhos de classe e em uma reunião realizada por 
Neide, a diretora, com todos os pais e mães de alunos. Assistiu-se, ainda, às festas e aos eventos promovidos pela escola, ao desfile cívico escolar anual de 1999 e a alguns "FISE" (Final de Semana do Escolar). O propósito que orientou a permanência da pesquisadora na escola foi conhecer o cotidiano escolar, beneficiando-se do livre acesso dos pais e das mães para favorecer o contato com estes últimos, deixando sempre clara a condição de independência dela em relação à direção da Altino Malafaia.

Desse modo, atendendo às exigências de uma pesquisa de cunho etnográfico, realizouse parte da coleta de dados com observações efetuadas na própria escola, em que se pôde verificar diferentes situações de participação. Completou-se a coleta de informações com entrevistas do tipo semi-aberto, com roteiro semi-estruturado, em que se procurou conhecer a opinião dos pais e mães de alunos a respeito do que eles entendiam por participação na escola de seus filhos e as situações em que essa participação acontecia. Além desses aspectos, procurou-se, ainda, saber dos entrevistados quais eram os problemas da escola, e, ainda, do bairro, com o intuito de averiguar se houvera (ou se havia) algum tipo de encaminhamento coletivo para solução daqueles problemas, que viabilizasse a forma mais conhecida de participação, a participação em ações coletivas.

Tendo em conta que a questão que deu origem a este estudo surgiu de um reconhecimento de um tipo não suficientemente explorado de participação de pais e mães de alunos, foi este o critério inicialmente seguido para orientar a escolha dos entrevistados. Assim, selecionou-se, para um aprofundamento da questão por meio de entrevistas, pessoas que haviam manifestado alguma espécie de discordância em relação a procedimentos da escola. Mas não se adotou exclusivamente este critério como 
parâmetro para investigar a questão da participação dos pais e mães de alunos pois outro pareceu igualmente relevante e complementar: a presença freqüente na escola, sugerindo o acompanhamento cotidiano do que acontecia em suas dependências, e, portanto, alguma elaboração crítica dos procedimentos escolares. Considerou-se, ainda, que pais e mães que estivessem na dupla condição de responsável por aluno e de próprio aluno - freqüentando o curso de Educação de Jovens e Adultos - poderiam dar testemunhos mais completos da vida escolar e, com essa justificativa, adotou-se mais este critério para estudar o problema da participação.

Assim, observando aqueles critérios, selecionou-se para entrevista nove mães e um pai (Bete, Elisa, Ivete, Ivone, Marta, Neusa, Nice, Rosa, Rute e Seu Campos). Desse conjunto, Bete, Ivete, Ivone, Neusa, Nice, Rosa, Rute e Seu Campos não se opuseram em conversar com a pesquisadora em suas respectivas residências; Elisa e Marta alegaram que havia obras em suas respectivas casas, o que, segundo ambas as mães, inviabilizava o ambiente doméstico para a atividade. Nesses dois casos, as entrevistas foram realizadas na escola ${ }^{23}$.

Com o decorrer da atividade, essa lista original foi acrescida de três pessoas - duas mães e um pai (Cida, Zefa e Chico) - , totalizando treze os entrevistados.

Cida, Zefa e Chico vieram a ser incluídos na lista original em decorrência de indicações. Ao entrevistar Ivete e Ivone, ambas mencionaram Cida como uma das mulheres que haviam organizado uma paralisação na rodovia federal, após inúmeros atropelamentos

\footnotetext{
${ }^{23}$ Após uma primeira entrevista com Elisa, realizou-se uma segunda, já em sua residência, para aprofundamento de aspectos da primeira. Uma segunda entrevista também foi realizada com Seu Campos pela mesma razão.
} 
com mortes. Cida era tia do marido de Ivete e tinha sido amiga de infância de Ivone, em município próximo. Ao se ter a informação de que Cida era mãe de aluna da Altino Malafaia, considerou-se que deveria ser entrevistada, pois se vislumbrou aí, nessa situação, a participação em ações coletivas.

De modo análogo, Nice, Ivete, Ivone e ainda Cida fizeram referência a Chico como um dos organizadores da caravana que se dirigiu à Prefeitura para protestar contra a demissão de Neide do cargo de diretora da Altino Malafaia ${ }^{24}$. Já se tinha conhecimento de que Chico era pai de dois alunos da escola por Nice, sua mãe, e, levando em conta o mesmo motivo da entrevista de Cida, decidiu-se entrevistar Chico.

Por outro lado, Cida mencionou, além de Chico, Zefa como mãe de aluno da Altino Malafaia que havia participado da paralisação na rodovia federal.

Portanto, foi uma rede de relações que orientou a ampliação da lista original de entrevistados, tendo em vista os benefícios que poderia trazer para este estudo a possibilidade de se cotejarem formas distintas de participação: a participação coletiva e a participação fragmentada.

Todas as entrevistas foram gravadas em fita de áudio, com exceção de uma, atendendo pedido da própria mãe, apesar de ter ficado claro que não se revelariam as fontes das informações, procedendo à mudança dos nomes dos entrevistados. Em outra entrevista gravada, houve manifestação de receio de identificação posterior, que pareceu sanada com o compromisso de alterar os nomes dos entrevistados e da escola.

\footnotetext{
${ }^{24}$ Vale mencionar que Cida também foi citada por Nice, Ivete e Elisa como uma das organizadoras dessa manifestação.
} 
Todas as fitas foram transcritas por profissional, trabalho posteriormente revisto pela pesquisadora, ao qual foram acrescentadas observações pessoais obtidas no momento das entrevistas.

\subsection{A concepção de particípação dos pais e mães}

Tanto pais quanto mães compartilham de um modo de conceber a participação associado à presença em reuniões na escola e à contribuição material para os eventos festivos na unidade escolar. Esses aspectos podem ser depreendidos das respostas que, invariavelmente, se seguem à pergunta: “O (A) senhor(a) acha que participa da vida da escola de seu(sua) filho(a)?”:

“Agora, eu estou participando menos nesse negócio. Porque, agora, além de eu trabalhar, quando cai uma reunião de pai de aluno, se cair no dia do meu trabalho, eu não posso ir, se cai no dia que eu tô de folga, eu vou." (Rosa)

"Participar, eu participo. Não vou dizer que eu participo de todas as reuniões que têm ali, sabe por quê? Porque muita gente não vai pra reunião ... eu vou pra reunião pra saber do problema do meu filho. Muita gente aqui, eles confundem, vai pra reunião pra conversar de casa, coisa que tem que conversar em casa, ou na rua, que seja." (Zefa)

"Participo. Às vezes, eu nem posso vir na festa, mas eu dou a prendazinha, eu faço questão de dar. A gente não pode, não é rica, mas eu gosto de dar. Igual nesse ano que passou, eu não pude vir, nem ele dançou, mas eu dei a prendazinha, dei o dinheiro pra fazer a festinha, quando é festinha na sala eu também dou dinheiro, participo. (Marta)

Confrontada com outras práticas de participação, mais diversificadas e mais ativas, mostradas por esses próprios pais e mães, a concepção de participação que eles possuem revela ser tributária de uma representação social que é admitida e incentivada pela própria instituição escolar. Por conseguinte, respondem ao questionamento da pesquisadora sublinhando uma atuação que, presume-se, corresponda à expectativa social relativa à participação. 
É do conhecimento de todos aqueles que estudam a democratização da gestão no sistema público de ensino como o corpo administrativo e o corpo docente das escolas, em geral, compreendem o que deve ser a participação de pais e mães de alunos: limitada à presença em reuniões para tomar ciência do desempenho escolar dos filhos, ou ainda, em situações excepcionais, para legitimar decisões tomadas anteriormente $\mathrm{e}$ internamente pela própria instituição, a participação dos pais e mães de alunos na escola também é admitida e estimulada sob a forma de trabalho dos pais e mães ou de contribuição em dinheiro, escamoteando a obrigação do poder público para com um serviço que já está sendo pago por todos os cidadãos através dos impostos.

Nesse contexto, a presença em reuniões e a contribuição material para a escola correspondem a uma expectativa decorrente de um modo de representar a realidade que orienta a experiência dos atores, levando-os a associar a participação a essas práticas.

Se essas duas práticas são consideradas, tanto por pais quanto por mães, formas de participação, é possível que outro fator colabore para que as representações cumpram o seu papel no ordenamento e na estabilidade das interações sociais: o gênero.

O conceito de gênero tem sido utilizado por certos autores (Connell, 1995; Lamas, 1995; Scott, 1995; Osores, 1997) para ressaltar a influência da cultura e da história nas relações sociais entre os sexos, para além da determinação biológica como elemento explicativo das diferenças sexuais:

"Este fato biológico [a diferença sexual], com toda a carga libidinal que carrega, é matéria básica da cultura. No nascimento se dá início à lógica do gênero: em função da aparência externa dos genitais, se fala de uma certa maneira à pessoa, trata-se essa pessoa de um modo diferente, [...] se depositam sobre ela certas expectativas e desejos. 
Assim se desenvolve o processo de atribuição de características "femininas" e "masculinas" a cada sexo, a suas atividades e condutas, e às esferas da vida." (Lamas, 1995, p.62, grifo no original)

Para Robert Connell (1995), na estrutura das relações de gênero, as masculinidades são constantemente re-construídas através de configurações de práticas que envolvem relações de poder, relações de produção e relações de investimento psíquico. Como decorrência da hegemonia de uma certa configuração de masculinidade tem-se o predomínio de uma determinada configuração de feminilidade, em torno das quais se definem características tidas como "masculinas" e características tidas como "femininas".

No modelo de maternagem ${ }^{25}$ vigente entre nós, entre as atribuições da mãe está o zelo pela educação dos filhos. (Carvalho e Vianna, 1994) A força desse modelo impregna as identidades das mulheres-mães fazendo, certamente, com que estas reiterem em suas falas o compromisso com o cuidado com a educação dos filhos, demonstrado pela presença nas reuniões e pela contribuição material nas ocasiões festivas.

Nesse contexto ainda, a doação de dinheiro que os pais e as mães fazem para a realização das festas induz-nos a perceber como a identidade de gênero pode expressarse - e, ao mesmo tempo, recriar-se - através da atuação cotidiana (Osores, 1997). Assim, quando se coloca em questão se a doação de dinheiro para as festas é tarefa dos pais e das mães, ou se, ao contrário, não seria atribuição do poder público, mas que os pais e as mães acabam assumindo, a argumentação destes vem reforçar os significados sociais

\footnotetext{
${ }^{25}$ Embora, no texto de 1994, Marília Carvalho e Cláudia Vianna utilizem a expressão 'modelo de maternidade', a própria Marília Carvalho diferencia, em trabalho posterior, os termos 'maternidade' e 'maternagem', razão pela qual faço a alteração: "O termo 'maternagem tem sido utilizado na área de estudos de gênero para expressar os processos sociais de cuidado e educação de crianças, em oposição à 'maternidade', que se refere à dimensão biológica da gestação e do parto. (Carvalho, 1995)
} 
do que é feminino e do que é masculino. Enquanto a mulher reforça o papel da mãe zelosa, o homem reforça o papel do provedor: na condição de mãe, a mulher destaca o benefício para a criança que a doação de dinheiro traz, ao passo que o homem, na condição de pai, enfatiza o benefício para a escola que aquela prática acarreta, ainda que, indiretamente, esse benefício possa ser revertido para seus filhos:

"Não é obrigação de pai de aluno, mas a gente colabora porque a gente quer o melhor. Porque eu acho que incentiva a criança, a criança gosta, né. E eu não gosto de deixar ela pro lado de fora. (Ivete)

"Pelo dinheiro que é passado para os municípios pra dividir com as escolas, seria da Prefeitura. [...] Mas a gente como empresários, como comerciantes aqui dentro, a gente tenta ajudar a escola. Sem aumentar o orçamento dos pais, eles não esquentam em ajudar, porque a escola, hoje, ela se tornou uma das melhores escolas, né, uma escola que você entra, é toda limpa, parece uma escola particular. (Chico)

Se as representações sociais acerca do que é concernente ao homem e do que é concernente à mulher ajudam a consolidar as identidades masculina e feminina, neste caso através das justificativas para a participação sob a forma de contribuição em dinheiro para a escola, também em outras situações a identidade de gênero pode funcionar como um guia para a ação, orientando a experiência de pais e de mães, como veremos a seguir.

\subsection{Outras práticas de particípação}

A não-correspondência entre o que era dito e o que era feito por pais e por mães no que se refere à participação ensejou que nos detivéssemos em examinar as razões pelas quais, no que era dito, a participação estivesse restrita à presença em reuniões e à colaboração material para a escola, enquanto que, no que era feito, houvesse outras práticas mais ricas e mais ativas de participação. 
Se a concepção de participação dos pais e das mães na escola pública se move no âmbito das representações sociais acerca da participação, as práticas de participação escapam a esse círculo restrito para revelar uma variedade de situações em que pais e mães se envolvem no cotidiano escolar, não apenas mas também para proporcionar aquilo que consideram ser uma boa educação para seus filhos.

Um dos modos pelos quais as mães mostram o zelo com a educação dos filhos, correspondendo ao modelo de maternagem vigente entre nós, é através do acompanhamento do desempenho escolar (Carvalho e Vianna, 1994). Algumas mães entrevistadas revelaram possuir interpretações bastante singulares a respeito dessa sua atribuição, demonstrando participar de forma muito intensa da vida dos filhos.

\subsubsection{A luta pela educação dos fithos: Marta}

Marta é uma jovem mulher cuja vida tem sido de muitas dificuldades. Conheci-a em uma de suas idas e vindas diárias para trazer e buscar seus filhos na escola. À espera do sinal de entrada, sentava-se sempre no mesmo banco com os filhos Francisco e Miguel, circunstância que aproveitei para entabular conversa com ela. Apresentando-me como pesquisadora, informo-a dos propósitos do estudo, perguntando-lhe se poderia conceder-me entrevista.

Ao ouvir sua história de vida, posso perceber a imensa esperança que Marta deposita na educação como alternativa que seus filhos têm a um destino que a ela e a seu marido já havia sido reservado. Relatando-me as dificuldades por que passou após o casamento, ela se emociona ao lembrar que já morou "dentro da casa dos outros" e "em barraco de tábua", dizendo não querer que os filhos "passem isso": 
"É o que eu falo pra eles: 'Olha, meus filhos, o que eu e seu pai não tivemos não quero que vocês, amanhã, não tenham. Não estou pedindo pra vocês trabalhar e nem pra estudar pra me dar as coisas pra mim criar, não. Eu nem sei se vou pegar vocês rapazes, né? Mas pra vocês terem uma vida melhor."

Em sua luta pela educação dos filhos, Marta conta de suas diligências para conseguir vaga em escola. Na primeira tentativa, apesar de ter-se levantado de madrugada para tentar matricular Francisco e Miguel em colégio municipal, não foi bem sucedida: “o nome deles não tava na lista”. Dirigiu-se, então, à Secretaria de Educação, e acabou conseguindo vaga, apenas para Miguel, em uma escola estadual, distante de sua residência:

"Eu andava muito, porque eu morava cá em baixo, eu andava meia hora daqui ao Clodomiro, todo dia, ia e vinha pra levar ele, com chuva, atravessar a rua, subia morro e tudo pra levar ele para estudar."

Francisco só foi para a escola no meado do ano quando a Prefeitura instalou um anexo de uma unidade de ensino fundamental em uma igreja.

Além das dificuldades que enfrentou para que seus filhos tivessem acesso à escola, Marta se empenha, ainda, para que eles permaneçam nela e se apropriem do conhecimento fornecido pela instituição escolar que - ela supõe - lhes dará passagem para uma vida melhor. Todo o seu relato está centrado em seu esforço, como mãe, para que Francisco e Miguel compreendam o que lhes está sendo ensinado. Com esse propósito, ela não apenas vai às reuniões convocadas pela professora de Francisco, que está na $2^{\mathrm{a}}$ série, como também procura cada professor de Miguel, que está na $5^{\mathrm{a}}$ série:

"Porque na $5^{\mathrm{a}}$ série não tem reunião, aí a gente tem que pegar cada dia uma professora e conversar, né."

Nessas ocasiões, Marta intercede por seus filhos: 
"Aí eu venho aqui e converso com a professora por causa de que aconteceu aquela nota e tal, e ela falou: 'Ele está com dificuldade e tal.' Aí eu peço a ela pra dar uma explicação pra ele."

Nessas ocasiões, ainda, Marta se dispõe até mesmo a aprender para ensinar seus filhos:

“... eu venho à escola, eu vou na sala; quando eu acho que ele está com alguma dificuldade em alguma matéria, eu vou lá e converso com o professor. Eu peço pro professor pra me ensinar, pra eu ensinar a ele, porque eu estudei pouco, dificuldade, né, eu estudei pouco, até a sexta série."

$\mathrm{Na}$ determinação de fazer com que seus filhos assimilem o saber escolar, também as tarefas domésticas são deixadas em segundo plano:

"Quando é época de prova eu não faço nada em casa, fico ali, só sentada com ele, estudando com ele."

Como se pode verificar, em suas atribuições de mãe, Marta inclui, de maneira inequívoca, o cuidado com a educação dos filhos, que não se limita à simples tomada de conhecimento do desempenho escolar de Miguel, mas que se realça no pedido de uma atenção particular dos professores para seu filho e na sua disponibilidade de aprender com o intuito de ensinar Miguel. O cuidado com a educação dos filhos é compreendido por Marta de modo tão imperativo, que ela, mãe, acaba por identificar-se com a situação do próprio filho, aluno, e, em decorrência, é o preparo da própria Marta para as provas que se torna parâmetro para o preparo do filho:

"Como a prova de ciência do meu filho. Eu falei pra professora: 'Se eu fosse fazer essa prova, eu fazia todinha agora, porque eu estudei tudinho.' Já sabia tudo de cor, e aí eu vinha lá de casa andando e perguntando e falando, e ele respondendo."

O significado que Marta concede à educação como um dos poucos bens que ela e o marido podem legar aos filhos ressalta-se ao longo de todo seu depoimento, como consequiência das agruras de uma vida de necessidades: 
“Eu falo pra eles: 'O que eu não tive, eu quero dar pra vocês.' Porque hoje em dia está difícil, né, você tem um serviço só pra comer; não dá pra comprar uma coisa, querer possuir um bem..."

É por esse motivo que o extremo cuidado com o estudo dos filhos destaca-se em sua fala, centrada em seus esforços, como mãe, para que Francisco e Miguel tomem posse do conhecimento escolar. Embora não minimize a participação do marido nessa tarefa, fazendo referência a este em momentos críticos, é a si mesma que Marta atribui a maior cota de responsabilidade.

Em nenhum momento Marta põe em dúvida se o conhecimento que seus filhos vêm adquirindo na instituição escolar corresponderá, no futuro, a um trabalho que lhes dê um salário digno, um trabalho que lhes permita, não apenas "comer", mas ter "as coisas deles, deles mesmo, conseguido com o suor deles”. Para ela, essa não é uma questão. Toda a esperança em uma vida melhor está depositada, sem restrições, na educação, e a ela, mãe, compete o emprego da energia necessária para a consecução desse objetivo: "ver eles formado".

A luta que Marta empreende pela educação dos filhos tem para ela uma importância que deve ser entendida no contexto das dificuldades vividas no passado e no presente, que acabam por confiar ao conhecimento escolar a garantia de um futuro menos sofrido, menos penoso. Esse compromisso, que condiciona os esforços de Marta a uma vida melhor para seus filhos, é cumprido por ela de modo tão convicto, que, refletindo sobre os sacrifícios que faz para dar educação a seus filhos, Marta assim avalia, com uma expressão de satisfação no rosto:

"Mas, se Deus quiser, vai valer a pena, um dia vai valer; nem que eles falem: 'Mãe, não quero estudar mais.' Mas já estudou, já tá bom.” 


\subsubsection{O acompanhamento da vida escolar dos fithos: Ivone ${ }^{6}$}

Ivone é uma mulher de meia idade cuja vida, à semelhança de Marta, também tem sido de muitas dificuldades. Conheci-a em uma de suas idas à secretaria da escola para saber de seus filhos, Carlos e Janaína. Ao indagá-la da possibilidade de me conceder entrevista, Ivone faz questão de me indicar sua residência, acrescentando que eu poderia ir lá quando desejasse. Alguns dias depois, ao chegar à sua casa, vi, à porta, uma tabuleta que anunciava a ocupação de sua dona: "costureira".

Ivone me informa que, apesar de ter posto o anúncio, não tinha muitos serviços de costura, o que se podia presumir em uma localidade de moradias populares, quase sempre em construção, e em que as mulheres procuram fazer, elas próprias, as atividades domésticas em prol dos membros da família e da economia familiar.

Reconstituindo sua vida passada, antes de vir instalar-se naquele bairro, Ivone conta que já havia sido empregada em fábrica de costura em outro município, e que o fato de, dois anos atrás, ela e o marido estarem desempregados contribuiu para que aceitassem a sugestão de Cida, amiga de infância de Ivone, que morava em Itaguaí, e decidissem mudar-se para lá, mesmo sem ter nenhum trabalho assegurado.

Naquele momento, ela e o marido se preparavam para deixar a casa em que moravam, porque o dono, que a havia cedido em troca da vigilância da torre de transmissão de uma rádio local instalada no terreno e de pouco mais de dois salários-mínimos, não os

\footnotetext{
${ }^{26}$ Em pesquisa realizada em escola da periferia urbana da Grande São Paulo, cujo objetivo era estudar o papel da família no desempenho escolar de alunos do ensino público fundamental, Vitor Paro (2000) registrou depoimentos semelhantes a este, contrariando suposição corrente (entre professores e funcionários da escola) de que os pais não se interessam pela vida escolar de seus filhos.
} 
queria mais ali. O marido, o filho e o irmão de Ivone estavam, então, levantando um cômodo em outro terreno, às pressas, para abrigar a família.

Ao dirigir nossa conversa para sua atuação de mãe na escola dos filhos, logo me chama a atenção o acompanhamento minucioso que Ivone faz da vida escolar de Janaína e Carlos, que inclui a precaução em relação aos possíveis riscos existentes no percurso de ida e de volta da escola (embora esta estivesse situada na mesma rua onde moravam, há poucos metros dali):

"Eu tô sempre assim, não sou de ficar assim atrapalhando, sabe, mas eu estou sempre assim atenta. Levo ela, ou então meu filho, ou estão meu esposo levamos ela até a porta do colégio, buscamos até a porta do colégio..."

"Ele vai e volta sozinho. Mas eu acompanho ele assim: eu controlo ele no horário de chegar em casa, sabe? O horário de chegar em casa, eu dou uma hora pra ele chegar e ele, às vezes, ele sai do colégio e ele vem pra casa; às vezes, ele pode até sair, mas ele vem logo pra casa."

É nas ocasiões em que Ivone encontra outras mães na porta da escola que ela tem a oportunidade de saber a opinião das mães a respeito dos problemas afetos à unidade, qual a avaliação que fazem, o que estão articulando. Desse modo, o acompanhamento diário da filha à escola acaba por consolidar uma forma de acompanhamento que extrapola o simples acompanhamento físico:

"Não, ela não vai sozinha. Então, a gente está sempre assim sabendo, porque mãe é fogo, né, a gente está sempre vendo todas as mães na porta do colégio [...] A única coisa que eu ouvi em relação às mães falando é que parece que estão com um projetozinho pra mudar o portão do colégio. Porque fica nessa rua aqui, principal, então é muito perigoso em relação a carro, e parece que estão querendo botar pra rua do lado; é a única coisa que eu vi, assim, fora do normal, é isso. Estão querendo mudar, estão querendo, todas as mães, inclusive fazendo, assim, abaixo-assinado pra mudar."

Se a prevenção quanto aos perigos que se escondem no trajeto entre a casa e a escola permite a Ivone, pelo encontro com outras mães na porta do colégio, mobilizar-se para 
uma possível ação coletiva que irá beneficiar os filhos, isso não obscurece a dimensão individual, pessoal, que, no caso de Ivone, se expressa na necessidade de conhecer o comportamento dos filhos enquanto alunos:

"O meu filho tem dezessete anos, eu não sou aquela mãe que fica assim [aproxima seu corpo do corpo da pesquisadora como a indicar que fossem irmãs siamesas], mas de vez em quando, eu vou lá, e dou uma pesquisada, sabe? Pra saber como ele está se comportando. Procuro falar com a diretoria da escola. 'Ah, você é a mãe do Carlos?' Eu: 'Sou!' Depois até, fica todo mundo até encarnando nele: 'Ih, sua mãe veio aqui, hein!' [...] Ele fala assim: 'Mãe, não faz eu pagar mico não.' Eu falo: 'Tá bom, pode deixar que eu não vou fazer não.' Mas quando eu chego lá: 'Mãe, pode ficar tranqüila, Carlos é um menino muito bom, é um menino calmo, é um menino educado.' O que eles me dizem é isso. Porque, creio que fosse ao contrário, elas iriam me dizer o contrário."

Ivone qualifica como "uma benção" o fato de Janaína nunca ter repetido série, mas, em relação a Carlos, conta que, em certo momento, ele quis deixar de estudar. Foi "uma fase muito difícil" porque Carlos, segundo a diretora da escola em que estudava, "parava no tempo":

"Foi problema com meu marido. Foi problema sério com meu marido. Meu marido teve, assim, uma época de beber, beber, e mexeu muito com a família, mexeu muito com a estrutura da gente. [...] E, aí, pronto, isso prejudicou muito a cabecinha dele, porque ele ficava preocupado [...] Lá na escola, lá do Rio, a professora falou que ele sentava na sala e ficava, assim, parado, e batendo assim com a caneta, sabe? E aí ela me chamou, eu conversei com ele, ele me disse que ficava com medo de chegar em casa e meu marido, por estar bêbado, querer me matar. Aí eu conversei com ele, falei que não era nada disso. Aí ele foi se recuperando. [...] Por isso que ele está atrasado. Tanto é que eu nem cobro muito dele, e nem posso cobrar, né, foi uma fase muito difícil da minha vida."

No entanto, não é essa compreensão quanto às dificuldades por que passou Carlos, e que o levaram a ser reprovado diversas vezes, que detém Ivone em suas atribuições de mãe, no que se refere à vigilância e ao acompanhamento escolar dos filhos. É o que se pode depreender quando, indagada se Janaína e Carlos são bons alunos, Ivone responde marcando sua atuação de mãe: 
"Sempre foram bons alunos, nunca tive queixas assim. E eu sempre trabalhei fora também, mas eu sempre acompanhava. Eu sou tipo aquela mãe, sabe, que não deixo pra lá não, eu sou aquela mãe que reviso pasta, eu sou aquela mãe que revisa caderno, sou aquela mãe que quero saber que matéria que estudou, quero ver a data. Entendeu? Eu não sou aquela mãe que deixa por conta do filho não, eu sou aquela mãe meio careta, sabe, corro atrás mesmo, porque, né, o mundo, ele proporciona muita coisa, né, e se a gente, como mãe, não toma conta, né, depois a gente vai chorar, né. Então, eu sou aquela mãe que acompanho mesmo, e quando não faz, eu pego, eu brigo, eu boto de castigo, eu chamo atenção duro, e mais tarde eles vão me agradecer, né. Eu sou esse tipo de mãe.”

Como se pode observar, Ivone, à semelhança de Marta, tem uma compreensão bastante singular do que é atribuição sua, como mãe, no que se refere ao zelo com a educação dos filhos. Essa interpretação pode ser entendida em um contexto em que o estudo é valorizado pelas perspectivas de sobrevivência que abre. Reportando-se ao momento em que Carlos queria deixar de estudar, Ivone fala de sua insistência com o filho, tentandoo convencer a não fazê-lo com a argumentação de que no estudo "estava o futuro dele", para, logo em seguida, referir-se a sua própria situação:

"Porque... eu sou costureira, sou profissional, é uma profissão que não exige muito assim, mas se eu tivesse mais estudo, eu tinha muitos meios de desempenhar a minha profissão. Entendeu? Eu acho que eu teria muitos meios de desempenhar minha profissão. E exatamente, se eu também tivesse mais estudo aqui, se eu não arrumasse em costura, eu arrumaria em outras coisas, mas quando chega no estudo, eu perco."

Se a mãe não deixa de acalentar aspirações em relação aos filhos, conjecturando o futuro deles, no caso de Ivone esse anseio toma a forma de um projeto que incorpora a idéia de educação como uma necessidade real; assim, mais do que um vir-a-ser ainda indistinto, mais do que uma expectativa incerta, nebulosa, quanto aos benefícios da educação, existe uma certeza, que se origina da própria experiência de Ivone, das vantagens que o estudo proporciona a quem o tem. Ao lhe perguntar, então, por que não voltava a estudar, Ivone responde com muita ênfase:

"Pra te ser sincera, esse ano eu estou com uma vontade imensa de voltar a estudar. Eu tô. Tá todo mundo me encarnando: 'Ih, você vai pra primeira série.' Eu digo: 'Vou tranqüila.' Eu tô com muita vontade de voltar a estudar esse ano." 


\subsubsection{A busca do aprendizado dos fithos: Bete, Ivete e Zefa}

O acompanhamento do desempenho escolar realizado pelas mães permite, a algumas delas, avaliar se os filhos estão dominando os conteúdos curriculares inerentes à série em que se encontram e, como decorrência, se estão aptos a passar para a série seguinte. É o que ocorre com Bete, mãe de Carla, que justifica sua avaliação depois de constatar que a filha "estava escrevendo muito errado" e que "em matemática, ela estava péssima":

"Ela [a professora da filha] falou: 'A Carla, ela não é uma aluna ótima, e também não é excelente, ela é regular. Mas se puxar mais por ela, ela tem condição.' Eu falei pra ela que por mim ela não passava para a $5^{\text {a }}$ série."

É também o que ocorre com Ivete, mãe de Gisela, que chegou a contratar os serviços de uma professora particular para suprir as deficiências do ensino a que sua filha estava submetida na escola pública, e que atribui o conhecimento que sua filha possui na série em que está ao trabalho da professora particular:

"Então o CA [Classe de Alfabetização] dela foi fraco, com uma professora que era muito boa, muito amiga, muito carinhosa, mas que não era aquele tipo de professora, assim, que dava duro na criança. [...] Aí, quando ela entrou pra primeira série, senti aquela dificuldade dela de pegar as coisas. Aí fui e botei na explicadora. [...] Aí eu não quis mais tirar ela da explicadora porque eu achei que, além do ensino estar fraco [...], a Renata [professora da filha na escola pública], ela acha que ... não deve cobrar tanto do aluno, sabe. Então, ela deixa correr muito frouxo. [...] Depois eu fiquei pensando: se eu tirar, deixar só por conta da Renata, ela [a filha] vai passar porque a Renata passa a mão na cabeça. Só que eu vou tá ciente que ela tá passando pela professora, e não por ela saber. Aí eu não tirei, continuei com a explicadora."

O que chama a atenção em ambas atitudes é o fato de as duas mães disporem de uma explicação das razões que levaram suas filhas a não dominar os conteúdos curriculares. Bete, ao refletir sobre os motivos pelos quais sua filha Carla estava péssima em matemática, julga ter sido um erro passar conteúdos novos no fim do ano letivo: 
"Porque no final do ano, eles passaram um montão de conta, conta que deveriam ter passado no começo, porque no começo tem revisão, por causa das matérias que fez no ano anterior, depois pulava para matéria nova, né. Não! Começaram a passar conta, assim, de dividir, essas coisas, de dois números, porcentagem, no final do ano, que já estava iniciando o final. Aí, em matemática, ela estava péssima.”

Ivete, ex-aluna do Projeto Educação de Jovens e Adultos, faz uma avaliação mais abrangente, questionando decisões de natureza político-pedagógica:

"Por esse negócio de CA passar automaticamente, eu acho que, por aí, os professores deixam as crianças muito livre. E quando chega na primeira série, eles se deparam com uma novidade. Por quê? Porque na primeira série a criança tem que saber ler, tem que saber escrever."

e até mesmo a qualidade do ensino público:

"[...] porque, agora, o ensino não é mais o professor que faz a base, a base já vem da Secretaria de Educação. Então, eles [os professores] têm que jogar pro aluno o que vem de lá. E eu acho que, agora, ficou muito fraco. Eu acho que a Secretaria tá deixando correr muito frouxo. Tá muito devagar."

No entanto, mesmo sabendo que os motivos pelos quais suas filhas não dominam os conteúdos que deveriam dominar são de natureza interna à escola ou ao sistema de ensino, tanto Bete quanto Ivete não reivindicam um direito que é delas, enquanto cidadãs, de verem suas filhas desfrutando de um ensino público de qualidade: enquanto Ivete lança mão de solução privada - contratação de professora particular - para um problema que é público - política educacional equivocada, má qualidade de ensino - , Bete simplesmente pleiteia a reprovação de sua filha, ainda que, posteriormente, à semelhança de Ivete, tenha providenciado professora particular para Carla.

No campo da educação, todos aqueles que se dedicam ao estudo do problema da reprovação escolar não desconhecem o processo de naturalização do fracasso escolar conduzido pela instituição escola que, apoiada em um discurso pretensamente científico, reduz o fracasso a uma simples questão de incapacidade pessoal. Maria Helena Souza 
Patto (1996) mostra como a concepção das famílias pobres, enquanto portadoras de todos os defeitos morais e psíquicos, legitima a ação dos educadores, eximindo-os da responsabilidade pelo insucesso na aprendizagem e imputando a culpa aos próprios alunos e/ou à sua família. Mais recentemente, Vitor Henrique Paro (2001) relaciona, entre os determinantes que influenciam a postura contrária à aprovação automática na escola, fatores socioculturais que, fundamentando-se na negação da condição de sujeito do aluno e no reforço do autoconceito negativo deste, acabam por fazer da reprovação uma estratégia de ensino. Assim, a reprovação como recurso didático-pedagógico a "motivar" o aluno para o estudo é justificado pelos que defendem a reprovação escolar, na medida em que o educando não é concebido como sujeito de seu próprio aprendizado, sujeito que, ao ser estimulado pelo educador a reconhecer o valor intrínseco do estudo, se sente automotivado para conduzir o processo de aprendizagem. Nesse contexto, a ameaça da reprovação concorre para escamotear a responsabilidade dos professores no processo, uma vez que, abstendo-se de lutar pela melhoria do ensino e das condições de aprendizagem que converteriam o aluno em sujeito de seu próprio aprendizado, não lhes resta outra saída senão colocar neste último toda a culpa pelo desinteresse no estudo.

Ainda na dimensão sociocultural dos condicionantes que favorecem a postura contrária à promoção automática na escola, Paro (2001) mostra também como o sentimento de competitividade, reforçado por uma sociedade cuja estrutura econômica se baseia na realização do lucro privado, acaba contagiando a instituição escolar que sustenta sua razão de ser em uma função credencialista e, por extensão, os próprios pais e mães de alunos, que, socializados na ideologia da competição, não conseguem conceber um 
ensino ao qual seus filhos possam aderir sem o prêmio - a aprovação - ou sem o castigo - a reprovação.

Ainda que, em um primeiro momento, possa parecer que as duas mães, Bete e Ivete, partilham desse modo de pensar, ao menos no caso de Ivete não se observa o sentimento de competitividade que, inerente à valorização do credencialismo, torna a promoção escolar símbolo da capacidade e do mérito pessoal. Ao se reportar à passagem de Gisela da primeira para a segunda série do ensino fundamental, Ivete mostra saber que o bom resultado de sua filha deve-se à intervenção da professora particular, não se importando em revelar o fato publicamente:

"Aí ela passou sabendo ler e escrever. Até a professora me chamou lá na frente na entrega do último boletim e falou que ela [a filha, Gisela] era um exemplo de aluna, que era esforçada, que Gisela era muito inteligente. Aí eu falei: 'Não tô desfazendo de aluno nenhum, só que ela também... ela é assim porque ela estudou em uma explicadora."

Corroborando essa observação e contribuindo para a formação de outro quadro interpretativo, pode-se supor que Ivete deseja que a filha aprenda de fato, não somente para evitar a reprovação, mas, para além disto, para se apropriar do saber escolar, e, com esse intuito, contrata os serviços de professora particular. Assim se pode compreender a justificativa que Ivete dá para a continuidade do trabalho da explicadora junto à filha:

"Depois eu fiquei pensando: se eu tirar, deixar só por conta da Renata [professora de Gisela na escola pública], ela [Gisela] vai passar porque a Renata passa a mão na cabeça. Só que eu vou tá ciente que ela tá passando pela professora, e não por ela saber. Aí eu não tirei, continuei com a explicadora." (Grifos meus.)

O que se quer destacar aqui é que o empenho de Ivete para que a filha domine o saber escolar, embora se escusando de reivindicar um direito que é seu, revela uma forma de participação que afirma, por via indireta, aquilo que deveria orientar a eficiência da escola pública: a busca contínua do aprendizado (Paro, 2001). Se, como ressalta Paro, é 
a realização do aprendizado que deve constituir-se a diretriz dos procedimentos didático-pedagógicos da escola, essa perspectiva é parcialmente percebida por Ivete, que busca o aprendizado da filha independentemente da responsabilidade do Estado nesse empreendimento. Assim, a mãe que deixa de lutar pela melhoria do ensino no âmbito público, contraditoriamente, se esforça para que a filha se aproprie do conhecimento escolar no âmbito privado.

A ausência de múltiplos e diversificados processos de construção de espaços públicos como fator fundamental no processo de constituição da cidadania tem sido destacada por todos aqueles que se dedicam ao estudo dos problemas afetos às sociedades democráticas. Nesse sentido, Norberto Bobbio (1997) lembra que, nos dias de hoje, o processo de democratização não se localiza tanto na passagem da democracia representativa para a democracia direta quanto na passagem da democracia política em sentido estrito para a democracia social, isto é, na extensão do poder ascendente do campo da grande sociedade política (o Estado e suas instituições) "para o campo da sociedade civil nas suas várias articulações, da escola à fábrica” (Bobbio, 1997, p.54$55)$.

Por certo, a negação da condição de sujeito do outro, como elemento sociocultural a avalizar um modo de produzir a vida em sociedade, em que as diferenças sociais e a presença generalizada da dominação nas relações entre as pessoas são tidas como necessárias (Paro, 2001), contribui para que, na esfera da política, não se estabeleçam os direitos, uma vez que estes instituem "uma forma de sociabilidade regida pelo reconhecimento do outro como sujeito de interesses válidos, valores pertinentes e demandas legítimas.” (Telles, 1994, p.91-92) 
Se processos de conscientização são desenvolvidos para restabelecer em cada homem a condição de ser humano histórico, sujeito de sua própria existência, e se, na esfera da política, firmam-se os direitos, uma noção mais ampliada de bem público pode ser construída na dinâmica mesmo da vida social, como expressão de um acordo circunstancial, resultante dos consensos, das diferenças e dos conflitos que manifestam os interesses e as aspirações daqueles que estão envolvidos em um pleito.

No âmbito da educação, a noção de bem público encontra-se bastante associada ao caráter público da atividade educativa mantida pelo Estado, isto é, como comprometimento do fundo público nas necessidades da reprodução social acima das relações privadas (Oliveira, 1998). No entanto, não é suficientemente destacado o sentido mais amplo da educação como bem público, que requer um espaço público no qual a pluralidade das opiniões de todos os envolvidos na atividade educativa pode expressar-se, no qual os conflitos podem ganhar visibilidade e no qual as diferenças se representam nas razões que validam os interesses e as aspirações defendidos como direitos (Telles, 1994).

Ao entrevistar Zefa, chamou-me a atenção o fato de ela, mãe de Elder e Ronald, alunos da $3^{\mathrm{a}}$ e da $2^{\mathrm{a}}$ séries da Escola Estadual Municipalizada Altino Malafaia respectivamente, estar, em diferentes situações, defendendo o interesse dos filhos de se apropriarem do saber escolar. No desempenho de suas atribuições de mãe, Zefa assume o interesse dos filhos e o transforma em sua própria aspiração, tentando instaurar na escola um espaço público no qual seus argumentos possam ser conhecidos: 
“... teve um ano aí que ... tipo uma discussão na escola por causa de professoras chegarem tarde. Eu tenho a minha responsabilidade de deixar a criança lá às sete e meia da manhã. Eu acho que ela também tem a responsabilidade de estar lá às sete e vinte da manhã pra poder receber o aluno, e não chegar às oito, oito e meia, porque aí ela vai ter que apressar a matéria. A criança não vai entender nada direito. [...] Porque o problema que ela teve foi porque ela falou que tinha um filho. Até ela falou: 'Eu tenho um filho, eu tenho que deixar na escola primeiro pra depois eu vir dar aula.' Eu falei: 'Você tem um filho, nós temos quarenta e poucos alunos dependendo de você. E você atrasa por causa de um filho seu? Quantas mães têm que trabalhar e arruma alguém pra trazer a criança às sete e meia da manhã?' Aí ... eu acho que até ela não gostou muito, porque depois reclamou com os alunos: 'Teve uma mãe aqui que não soube entender o meu problema.' Eu até entendo o problema dela, só que, antes, eu tenho que ver o problema do meu filho. Porque criança nenhuma vai aprender nada corrido. A criança já tem uma dificuldade de entender. Se você explicar correndo, como é que ela vai entender? Então eu reclamei. Algumas mães ficaram com raiva de mim porque eu reclamei. Eu não me importei, porque importa mais pra mim a educação do meu filho, não o que as outras pessoas estão falando."

A valorização do conhecimento que a escola pode fornecer aos filhos é tão assumida por algumas mães que elas não conferem mérito à bondade ou ao carinho de uma professora se estes atributos não vierem acompanhados da competência para ensinar. Parece ser este o caso de Ivete, mãe de Gisela, que assim explica o motivo pelo qual sua filha teve dificuldades na primeira série do ensino fundamental:

"Então o CA dela foi fraco, com uma professora que era muito boa, muito amiga, muito carinhosa, mas que não era aquele tipo de professora, assim, que dava duro na criança. Aí, quando ela entrou pra primeira série, senti aquela dificuldade dela de pegar as coisas."

Com uma ligeira variação, parece ser, também, o caso de Zefa, que, julgando que as mães ficaram com raiva dela pelo fato de a professora que ela havia criticado ser, na opinião destas, uma professora boa, bondosa, subverte o significado de "boa", associando-o à capacidade de ensinar:

"Mas ela [a professora substituta] foi uma professora boa, os alunos passaram porque ela deu em cima. Agora, se fosse a outra [a primeira professora] que tivesse ficado, eles poderiam até ter passado, mas iam passar arrastando [...] , com nota baixa." 
Uma observação a ser feita, a partir dos dois posicionamentos, o de Ivete e o de Zefa, é que a "dureza" da professora pode, muitas vezes, encobrir as precárias condições de aprendizagem, responsáveis por não tornar o estudo atraente para os alunos. Desse modo, a professora precisa ser "dura", precisa "dar em cima", porque, eximindo-se de lutar pela melhoria do ensino, tem que fazer do aluno um objeto de seu próprio aprendizado, ao invés de tê-lo como sujeito do processo, e, como decorrência tem que constrangê-lo, tem que ameaçá-lo. A fala de Zefa, em defesa da professora substituta, pode ser exemplo para esta situação:

"Olha, mil vezes a rígida, porque com a professora rígida o aluno entende mais as coisas. Com a professora que não tem aquele pulso forte, o aluno não entende nada, o aluno não liga, faz bagunça e tudo."

Embora Zefa não faça a crítica dos condicionantes socioculturais que impregnam sua maneira de perceber tanto o professor quanto o aluno, é preciso considerar o compromisso que esta mãe demonstra com o aprendizado do filho, e, ainda, a sua insistência em manter aberto um espaço público para defender este pleito. Ao se reportar ao período em que ocorreu a substituição da professora que chegava constantemente atrasada, Zefa relata o embate que teve com outras mães, no qual se destaca o empenho para que, não apenas seu filho, mas seu filho e os demais alunos dominem o saber escolar:

"Então eu preferi a outra [a professora substituta]. E as mães não, ficaram com pena dos filhos: 'Ah, tem matéria que meu filho não sabe, meu filho ainda não aprendeu.' Eu falei: 'Mas ele vai aprender.' A gente tem que querer o melhor para o nosso filho. A pessoa que pega duro com eles, está ajudando a quem? Está me ajudando, está ajudando a elas. Mas elas não gostaram, teve muita mãe que virou até a cara pra mim, e tudo. Eu não liguei, não."

A busca permanente do aprendizado como princípio norteador dos procedimentos didático-pedagógicos da escola, condicionada às condições adequadas de trabalho e aos 
métodos eficazes de ensino, pressupõe um conjunto de fatores que permitem fazer da educação uma "atualização histórico-cultural” (Paro, 1999, p.111) com vistas a propiciar aos alunos sua realização individual e social. Assim, o montante e a utilização dos recursos materiais e financeiros; a organização do trabalho; a formação, o desempenho e a satisfação do pessoal escolar; os currículos e os programas; a distribuição da autoridade e do poder na escola; e o planejamento, a avaliação e o acompanhamento constante das práticas escolares constituem alguns dentre os muitos elementos que, relacionados à estrutura e ao funcionamento da escola (Paro, 2001), tornam específica a função social desta instituição, que é não apenas ensinar, mas ensinar bem.

Ainda que Zefa não tenha pleno conhecimento da amplitude e da complexidade dessa tarefa, seu compromisso com a aprendizagem é tão marcante que ela revela ser esta sua compreensão da função social da escola. Mesmo não tendo uma experiência pessoal com Vera, professora da $1^{\text {a }}$ série do ensino fundamental e também professora de Religião, Zefa reconhece como válidas reclamações de outras mães acerca da falta de profissionalismo da professora, que não dá prioridade ao seu papel específico, que é passar os conteúdos curriculares concernentes à $1^{\mathrm{a}}$ série, estendendo a crítica à própria escola:

"Mas tem mãe que reclama muito, até hoje, da professora dali, da Vera, a professora Vera. Porque ela ... ela é de religião, ela é cristã. Eu também sou cristã, mas eu acho que tem que saber separar uma coisa da outra, né. Então ela dava mais atenção pras coisas da ... de ensinar as crianças a cantarem hino [religioso] para se apresentar, e coisa e tal, do que pra aula. Então, tem mãe que reclama: 'Pôxa, a Vera não dá atenção às crianças, grita muito com as crianças e cisma em ensinar as crianças a cantar para poder se apresentar.' Tem mãe que reclama, eu não tive a oportunidade porque meus filhos não estudaram com ela. [...] Porque ali eles se importam muito de fazer apresentações. Tudo bem, tem que ter, a escola precisa de apresentações, mas não é ... não é ... como é que eu vou falar? Não é assim tão ... tem que puxar mais pelo ensino, né. Porque se você quiser que seu filho seja religioso, você vai levar ele pra uma igreja, né. A escola ajuda, 
mas não tem tanta obrigação de fazer. [...] Quer dizer, eu acho que é uma coisa que não tem tanta necessidade, né."

Em resumo, embora Ivete e Zefa tenham posicionamentos diferentes em relação à responsabilidade da escola no cumprimento de sua função social - Ivete assumindo no âmbito particular a realização do encargo educativo e Zefa chamando a instituição no espaço público para a realização de sua incumbência - ambas mostram, na busca do aprendizado dos filhos, uma forma de participação que, inerente às atribuições da mãe no modelo de maternagem vigente entre nós, ajuda a reforçar a identidade de gênero, a identidade da mulher-mãe.

\subsubsection{O enfrentamento com a escola: Ivete, Neusa e Elisa}

O relacionamento das mães com o pessoal escolar é marcado muitas vezes por conflitos que decorrem da indefinição de suas esferas de influência. Marília Carvalho e Cláudia Vianna (1994) mostram como educadoras e mães de alunos sentem-se ameaçadas em suas respectivas identidades em decorrência de um modelo de maternagem que, atingindo também as educadoras - mulheres responsáveis pela educação das crianças na escola - , superpõe as atribuições desta e da família.

Na disputa sobre o controle das crianças, vigoram, portanto, entre mães e educadoras, acordos e desacordos em torno das ações e das condutas que, conformando o modelo de maternagem, devem concorrer para a educação dos pequenos.

No que se refere ao castigo físico, por exemplo, aquilo que pode ou não pode ser feito pelas professoras e pelas demais funcionárias da escola para corrigir o comportamento 
das crianças é questionado pelas mães em inúmeras situações, dado que não existe consenso sobre os limites da autoridade de ambas no cumprimento de suas funções.

Ivete, mãe de Gisela e Marcos, reage ao que considera extrapolação de poder do pessoal da escola. Ao notar que a filha estava chorosa porque, segundo esta, havia sido maltratada por funcionária da secretaria que, naquele dia, substituíra a professora, Ivete se insurge, tratando de demarcar as fronteiras entre o que procede da mãe e o que pode proceder da escola:

"Aí eu fui na secretaria, porque aí também quando mexeu com filho meu já era. [..] Eu sei respeitar os direitos dos outros, mas eu também quero que respeite o meu."

De modo análogo, essa mesma mãe, ao perceber que uma professora não cumpre as atribuições que julga serem dela, professora, reage cuidando de defini-las, e, em contraposição, cuida, também, de definir as suas enquanto mãe. A situação era a seguinte: Ivete estava em uma fila, na porta da escola, esperando para fazer a matrícula do filho Marcos, no momento em que os alunos estavam formados, no interior da escola, esperando a ordem de entrada para as salas de aula. Assim que percebeu que o filho da sogra, que estava em forma, brigava com outro colega, Ivete adentrou a escola para apartá-los, quando foi interpelada pela professora, que lhe perguntou o que estava acontecendo:

"O que tava acontecendo eu já resolvi, que é coisa que é pra vocês resolver. Que desde o momento em que um aluno entra dentro do colégio, cabe-se a vocês ficar ali, do lado dele. Tá na formação, vocês tem que ficar ali, olhando, pra saber o que tá certo, o que tá errado. [...] A educação do meu filho, que ele é como fosse meu filho, cabe-se a mim, não é a você não. Agora, desde o momento em que ele tá dentro do colégio, cabe-se a você tomar conta. Você não é supervisora? É pra isso que você é paga.”

Na briga em torno dos limites da jurisdição sobre o filho da sogra, que Ivete considera como seu filho, ela - que estudou na Altino Malafaia desde o tempo em que a escola 
ocupava as instalações de uma casa - lança mão do tempo de freqüência à instituição para questionar a legitimidade do poder da professora:

"Ela tem que saber que se ela é autoridade aqui [na escola] eu também sou. Porque ela entrou agora no colégio, e eu já sou do colégio há anos."

A ambivalência de sentimentos e de emoções vivida por mães e educadoras, decorrente de sua condição de mulheres que dividem a incumbência da educação de crianças e que comungam de um modelo de maternagem, obscurece a natureza diferenciada da interação de ambas com os pequenos. Embora compartilhem tarefas e saberes culturalmente atribuídos a uma natureza feminina, mães e educadoras escolares encontram-se, no ambiente escolar, em situações diferentes no que se refere à relação com as crianças: "enquanto as educadoras escolares são obrigadas a lidar necessariamente com o coletivo, uma vez que são responsáveis por muitos alunos, as mães podem se preocupar exclusivamente com seus filhos, o que faz com que a escola nem sempre possa responder às suas expectativas." (Carvalho e Vianna, 1994, p.138)

Neusa (mãe de Lúcia, Tiago e Roberto) faz muitas críticas à escola de seus filhos. Uma delas é quanto à dificuldade em conseguir vaga para Lúcia e Tiago. O tom ríspido de sua fala, acompanhado de movimentos bruscos do corpo, revela acerba revolta com os procedimentos da instituição. Em meados de 1998, Neusa conseguiu um emprego que a impedia de levar e buscar Lúcia na escola municipal Afonso Celso onde esta estava matriculada na Classe de Alfabetização. Por temer a travessia da rodovia federal que a pessoa que a substituiria naquela tarefa teria de realizar diariamente com sua filha, Neusa decidiu tirar esta da Afonso Celso na intenção de matriculá-la na Altino Malafaia. Como se pode presumir, encontrou dificuldades em realizar seu desígnio, visto que se estava no meio do período letivo, ocasião em que as vagas, via de regra, já 
estão todas preenchidas. No entanto, esta circunstância não é levada em consideração por essa mãe, cujo relato destaca a sua necessidade particular de matricular a filha, necessidade que, em sua perspectiva, toma a conotação de um direito: assim, Neusa invoca a condição de mãe que, atendendo ao seu dever perante o Estado, quer que a filha frequiente escola e, com esse argumento, denuncia a Altino Malafaia que, só por muita insistência sua, matriculara Lúcia no CA (Classe de Alfabetização).

No caso de Tiago, a reclamação de Neusa reitera a noção de direito à educação, quando persiste no pedido de vaga para o filho nas turmas do Pré-Escolar, após ter seu pedido negado por não ter apanhado a senha de matrícula. Nessa ocasião, Neusa reclama do horário em que as senhas foram distribuídas, de madrugada, e questiona a diminuição progressiva do número de vagas para o Pré: "primeiro eram 50, foram diminuindo pra 40, e depois pra 38". Depois da altercação, ao ouvir funcionária da secretaria dizer que "não havia necessidade de seu filho estar freqüentando escola por ter apenas cinco anos" - em uma atitude de depreciação do empenho da mãe em fazer a matrícula do filho - Neusa rebate afirmando que "não era isso que a televisão informava", em referência à publicidade governamental que incentivava os pais e as mães de crianças menores de seis anos a procurarem unidade escolar para matricularem seus filhos. Ainda que tenha arrolado todos esses argumentos - ou até mesmo, talvez, porque os tenha arrolado - Neusa não consegue a vaga para Tiago no Pré-Escolar da Altino Malafaia.

O enfrentamento com a escola que algumas mães realizam coloca as relações de poder como algo referido à dimensão doméstica e familiar da vida privada. Marília Carvalho e Cláudia Vianna (1994), apoiando-se nos trabalhos de Michelle Perrot, mostram que as 
educadoras parecem buscar na instituição escolar um lugar onde possam exercer seus poderes, como compensação de sua condição de mulheres que, de ordinário, estão à margem da vida política (pública) da sociedade; nesse movimento são seguidas pelas mães que, partilhando daquela mesma condição da mulher, vêem a escola como uma extensão do lar e disputam com as educadoras o controle sobre os filhos.

Assim, para as professoras, a autonomia do trabalho docente pode ser uma maneira de exercer o poder feminino no contexto das estruturas da dominação de gênero, bem como a tentativa de intervir na escola por parte das mães, que defendem a educação dos filhos como uma das poucas esferas em que sua atuação é legítima.

Se é o pedagógico, enquanto um domínio próprio de trabalho, que faz as professoras repelirem qualquer ingerência, seja das mães, seja dos especialistas em educação, naquilo que ocorre em suas salas de aula, essa autonomia docente se transforma em arbitrariedade docente quando a professora considera o aluno mero objeto de dominação na relação educativa. Vitor Paro (2001) mostra como a negação da condição de sujeito do outro, enquanto um fator sociocultural, pode interagir com as características e potencialidades biológicas e psíquicas, e com os demais condicionantes da vida privada do indivíduo, para configurar uma postura de resistência do professor à aprovação dos alunos. Por inferência, pode-se afirmar que o componente cultural que legitima relações de dominação - a negação da condição de sujeito do outro - , assimilado durante o processo de socialização primária do educador, ao encontrar na biografia pessoal deste um campo propício, pode configurar uma postura autoritária do professor na relação com os alunos. 
É o que parece acontecer com a professora Lurdes com quem Elisa (mãe de Juliana, Adriana e Saulo) teve que se defrontar por duas vezes. Elisa fala aceleradamente como se quisesse extravasar algo que estivesse contido desde há muito, mas sua postura não acompanha o frenesi do relato, com o corpo parado e as mãos sobre o colo.

Elisa, ao mencionar as dificuldades que as filhas apresentam na escola, diz que Adriana teve nota baixa em Educação Física porque "tem sopro no coração", diagnosticado por médico com quem faz tratamento à base de remédio. Assim, quando Adriana está muito cansada , quando "sente muita fisgada no coração", ela "não pode fazer [educação] física", razão de seu baixo desempenho. Quando pergunto a Elisa se ela havia informado à professora Lurdes a doença de sua filha, Elisa, surpreendentemente, me diz que não, porque já tivera desentendimento anterior com ela. Em seguida, emenda: "Eu tive problema com meu filho, com ela."

Segundo Elisa, Saulo perdeu a vontade de estudar, porque "se decepcionou [...] no colégio por causa da professora de Educação Física": "Ele perdeu o sentido, perdeu." De acordo com seu relato, pode-se concluir que Saulo deixou a escola na sétima série por ter sua auto-estima rebaixada, em decorrência da arbitrariedade da professora Lurdes e da insensibilidade da mesma professora à particularidade da condição de Saulo, que tem dificuldades para enxergar de longe.

Elisa mostra revolta quando fala dos dois problemas. Em sua acuidade de mãe, ela não consegue aceitar que um garoto que "não é ruim", "um garoto responsável”, não fosse capaz de ter sua permanência na escola estimulada por esta, assim como não consegue 
aceitar que a professora, ciente do problema de vista de Saulo, não reservasse lugar para ele, na sala de aula, perto do quadro-negro.

Reportando-se ao tempo em que Saulo freqüentava a Altino Malafaia, Elisa ainda hoje recusa-se a aceitar a nota baixa em Educação Física dada pela professora Lurdes porque seu parâmetro é aquele que deveria guiar as ações pedagógicas de toda escola: cativar o aluno para o aprendizado (Paro, 2001). Ainda mais um aluno esperto, que conseguiu aprender, na prática, um ofício:

"E o meu filho, um garoto responsável, pega cinco e meia no serviço e larga sete da noite, se ele fosse um mau garoto, ele não estava nem trabalhando, estava aí pelas ruas. Sendo que há dois anos ele trabalha nessa padaria, ele é padeiro formado, ele faz de tudo. Quer dizer, ele não é ruim."

Do mesmo modo, Elisa recusa-se a aceitar a aflição porque passou Saulo em conseqüência de sua dificuldade de visão, e que concorreu para que desistisse de continuar estudando:

"Aí cheguei aqui na escola, e encontrei ele fora da escola, aí fui procurar saber o porquê ele estava fora da sala de aula. A dona ali [a professora Lurdes] sabia que ele tinha problema de vista, que ele tinha que sentar na frente. Aí outro colega sentou no lugar dele. E ela não ligou. Aí eu cheguei no colégio e falei: 'Meu filho, por que você está do lado de fora?' Ele: 'Mãe, não tem cadeira pra mim.' Eu fui falar com a professora: 'Então procura cadeira na outra sala.' Eu procurei e não tinha, foi o maior tumulto por causa disso."

Mas se Elisa, por causa das contrariedades que teve com a professora de Educação Física, não comunicou a esta a doença da filha Adriana, que a impedia de fazer com regularidade as atividades - evitando um possível segundo enfrentamento - , com o problema surgido com a outra filha, Juliana, não se livrou de ter que conversar com Lurdes: "Tive que encarar ela, e falar a ela pela nota da menina." 
Segundo Elisa, Juliana e mais duas colegas foram incumbidas de fazer um trabalho escrito para o qual Juliana e uma colega realizaram pesquisa, enquanto a outra digitou e imprimiu o trabalho. Lurdes, ao receber o trabalho do grupo, deu nota apenas para a aluna que havia digitado e imprimido o trabalho, deixando Juliana e a outra colega sem nota. Juliana, então, pediu que a mãe intercedesse por ela, o que Elisa fez solicitando que a colega confirmasse o que havia acontecido efetivamente. Com a confirmação, Lurdes lançou nota para Juliana, mas não tratou as componentes do grupo com eqüidade:

"A minha filha ficou com setenta e a outra com noventa. Tá bom, pelo menos não vai reprovar ela. Ela estava sem nota nenhuma no terceiro bimestre. Ela colocou, ficou só com setenta. Tá bom. E vim embora, deixei."

O que chama a atenção em Elisa é que o vigor de suas denúncias, ressaltado pelo sentimento de indignação e pela aceleração de sua fala, traz em seu bojo, como seu oposto, a indolência da renúncia, marcada pelo sentimento de resignação e pela ausência de movimentos em seu corpo. Assim, se é a indignação que faz Elisa reclamar o fato de seu filho não estar assistindo aula, é a resignação que faz essa mãe silenciar sobre a doença de sua filha; se é a indignação que faz Elisa constatar:

"E eu não falto reunião, não falto a nada no colégio, pode ver meu nome, está tudo nos cadernos. Eu não falto, eu sempre estou com meu filho, sempre procuro a professora e pergunto como é que tá. Agora, acontecer isso, eu não ... eu corro atrás."

é a resignação que faz Elisa ponderar:

"Tá bom, pelo menos não vai reprovar ela. Ela estava sem nota nenhuma no terceiro bimestre. Ela colocou, ficou só com setenta. Tá bom. E vim embora, deixei.”

Considerando as dificuldades dos pesquisadores em interpretar a realidade das chamadas classes subalternas, José de Souza Martins (1989) chama a atenção para o 
conhecimento de que são portadoras essas classes, que não é tão-somente ideologia explicação necessariamente incompleta da realidade - mas "conhecimento acumulado, sistematizado, interpretativo e explicativo" (p.111), que tem nas relações sociais sua gênese e sua determinação. Ao reconhecer as classes subalternas como "sujeitos da história e sujeitos do conhecimento" (p.119), Martins afasta a representação de sua cultura como resíduo do arcaico, porque ela contém, em sua lógica, "elementos de explicação da mudança e das inquietações sociais e não apenas elementos de justificação do passado" (p.123). Desse modo, a tensão que perpassa a cultura popular, e que lhe dá um caráter de duplicidade, "remete para as contradições e para a diversidade de relações na qual essa cultura se atualiza, ganha e renova sentido" (p.118).

De modo análogo, Marilena Chauí (1994), ao se dedicar ao estudo da cultura popular, considera que esta é "um conjunto disperso de práticas, representações e formas de consciência que possuem lógica própria" (p.25), diferenciando-se da cultura dominante exatamente por esse aspecto. Observando a maneira pela qual a cultura popular constitui seus objetos, Chauí mostra que estes "nunca são dados, mas são postos por práticas sociais e históricas determinadas" (p.122), o que quer dizer que algo pode ser "isto e aquilo" se for percebido como tendo dimensões simultâneas que se legitimam, por exemplo, na relação com o necessário e com o contingente, com o possível e com o impossível, sob a dominação. Assim, a ambigüidade é uma forma de existência dos objetos da percepção (e da cultura) popular, pois que a ambigüidade integra uma racionalidade alargada que pretende dar conta daquilo que é real, no contexto de relações de dominação. 
É o que parece acontecer com Elisa que, submetida à prepotência de Lurdes, sabe que esta encontra na omissão da administração da escola amparo para o opressivo exercício docente, e que, em face dessa experiência real, decide quando não enfrentar:

"Eu acho que ela [a direção] podia tomar atitude. A direção quando sabe que tem professores que não têm competência, qual a obrigação dela? Chegar junto e falar. Só que ela deixava passar, ela não falava. [...] Então, quer dizer, a gente vai mexer, eles estão tudo grandão, a gente fica pichada, os filhos da gente, então a gente não pode fazer nada."

e quando enfrentar, em uma avaliação rigorosa do limite e do alcance de sua ação:

"Eu reajo. Alguma coisa que eu posso, eu falo, alguma coisa que eu posso, eu falo, alguma coisa que eu não posso, eu não falo."

\subsubsection{A participação no contexto de valorização da escola: Rute e Rosa}

O caráter clientelista da gestão da escola pública tem sido apontado como um fator que, fazendo desta arena de interesses pessoais e de favorecimento político, concorre para a resistência à democratização da gestão, já que se opõe à participação dos pais e mães de alunos. (Spósito, 1989)

Desse modo, uma concepção privatista da escola, que a toma como uma espécie de propriedade do governo e na posse do pessoal docente-administrativo, consolida suas características patrimonialistas $^{27}$, da qual partilham, muitas vezes, os próprios usuários que acabam por considerar a educação escolar como um benefício concedido pelo

\footnotetext{
27 "Segundo [Max] Weber, patrimonialismo é uma forma tradicional de organização da sociedade, inspirada diretamente na economia doméstica e baseada em uma autoridade santificada pelas tradições. [...] O poder político patrimonial vincula dominantes e dominados por meio de uma comunidade consensual $[. .$.$] que repousa na convicção de que o poder senhorial exercido tradicionalmente constitui$ direito legítimo do seu senhor. [...] Apropriando-se dos cargos administrativos e monopolizando-os, a dominação patrimonial não estabelece distinção entre as esferas pública e privada, confundindo-as no cotidiano em benefício dos seus interesses pessoais e do seu arbítrio." (Dicionário de Ciências Sociais, 1986, p.874)
} 
governo e não como a efetivação de um direito da população. (Pereira, 1967)

Nesse contexto, a falta de reparos e de críticas à atuação da escola pode ser interpretada enquanto decorrência de uma percepção deformada e ilusória, que, condicionada, no plano político-econômico, pela subordinação das camadas populares, e, no plano cultural, pela ausência de mediação de uma razão histórica, termina por menosprezar a responsabilidade social da escola e, conseqüentemente, por obscurecer suas fragilidades e deficiências no cumprimento de sua função.

Assim, a exploração econômica e a dominação política, conjugadas à inexistência de uma razão que desvendasse as representações e os valores concernentes ao exercício do poder em uma sociedade de classes, contribuiriam para que a falta de reparos à escola fosse subproduto de uma ideologia que encobriria a divisão social, fazendo com que as camadas populares reproduzissem em seu cotidiano mesmo a sua situação de classe.

Em seu trabalho como profissional de saúde pública, Victor Valla (1996) surpreendeuse com as concepções de lideranças das favelas da zona da Leopoldina (no município do Rio de Janeiro) que, expressando determinado conhecimento a respeito da distribuição irregular de água, orientavam sua conduta. No contato com essas lideranças, Valla observou que era preciso levar em conta as condições de vida dos moradores das favelas em sua dimensão subjetiva para que se pudesse compreender o significado (e a lógica) de suas falas bem como sua ação política, tal como José de Souza Martins (1989) havia observado em relação às classes subalternas de modo geral. 
Assim, Valla se deparou com resistências das lideranças das favelas à recomendação dos profissionais de saúde pública que, em face da distribuição irregular de água, insistiam na necessidade de a população organizar-se para reivindicar seus direitos. Para os moradores das favelas, que, em mutirão, organizados pelas Associações de Moradores, conseguiam "puxar" a água pelo menos três vezes na semana, aceitar a recomendação dos agentes de saúde e entregar a responsabilidade da distribuição da água à CEDAE - Companhia Estadual de Água e Esgoto do Estado do Rio de Janeiro representaria o fim da própria água.

Valla compreendeu, então, que a experiência histórica das condições de vida dos moradores das favelas, suas dificuldades de sobrevivência enfrentadas no passado, levava-os a uma determinada percepção da realidade que os mobilizava para prover o dia de hoje, e que resultava em uma avaliação conjuntural e material bastante dura dos limites de sua melhoria. Desse modo, ainda que em retribuição aos impostos pagos o Estado tivesse que oferecer serviços de qualidade (no caso, a água), a experiência real dos moradores das favelas mostrava a estes que a CEDAE não tinha uma política de distribuição de água que os beneficiasse, tendo que ser substituída nesse encargo pelas Associações de Moradores que, representando o esforço da população no mutirão, conseguiam trazer a água ao menos três vezes na semana. Nas palavras de Victor Valla:

"O raciocínio que eu utilizei era acadêmico e, diga-se de passagem, correto. Em troca dos impostos pagos, quem tem de oferecer serviços de qualidade é o governo e não a população numa espécie de mutirão. A resposta da liderança inverteu a lógica: se não fosse pelo esforço dos moradores, organizados nas suas associações, não haveria água nas favelas. O que ele queria dizer era que a CEDAE, na realidade, não tem política de distribuição de água para as favelas, mas que as Associações de Moradores conseguiram "puxar" a água através da sua organização, e não insistir nesta política significava abrir mão da água. Ou seja, atrás da fala desta liderança, havia uma resposta teórica para minha proposta teórica: os governos do Brasil não estão muito preocupados com os moradores de favelas na elaboração das suas políticas e somente o esforço dos moradores é que garante sua sobrevivência." (Valla, 1996, p.182) 
Assim, o que a experiência de Valla revela é que, na perspectiva de mudança da ação política das camadas populares, não conta apenas uma avaliação objetiva de suas condições de vida extraída de uma determinada orientação teórica, mas conta, ainda, e fundamentalmente, uma avaliação subjetiva de suas condições de vida, determinada pelas experiências de vida daquelas camadas e que orientam a sua conduta.

No que se refere especificamente à realidade escolar, tendo a experiência de Valla como referencial, pude observar que as condições de vida de duas mães de alunos da Escola Estadual Municipalizada Altino Malafaia, tal como ambas as vivenciaram, podiam ser o fio condutor para compreender o modo como representavam a escola.

Rute (mãe de Joana, João e José) está há quatro anos em Itaguaí, oriunda da zona rural do estado do Espírito Santo, onde tinha "uma vida muito sofrida":

\begin{abstract}
"A vida do colono, como se diz, o bóia-fria, lá, é muito sacrificada. [...] Se quer plantar alguma coisa, eu tenho que plantar a meia, e muito ... as coisas são muito caras. A gente tem que produzir pra comer, pra sustentar os filhos. Quer dizer, um quilo de açúcar, lá, hoje, deve estar custando, mais ou menos, uns dois reais, dois reais e cinqüenta. [...] Ou então, se a gente não quisesse ou não pudesse comprar o açúcar, uma coisa assim, tinha que plantar uma cana, moer aquela cana, tirar o caldo da cana pra poder fazer o café. Aí ... feijão, a gente plantava, o arroz também. E tinham outras coisas assim, como raízes: mandioca, a batata. O milho que fazia o fubá; a mandioca também fazia a farinha. Pescava o peixe, e fazia, às vezes, pirão. Se alimentava muito de peixe, então a gente se alimentava muito com peixe, e alguma criação que a gente criava. Mas dizer, assim, que a gente tinha aquela fartura, fartura mesmo, não."
\end{abstract}

Sua mudança para o Rio de Janeiro foi provocada por alterações no modo como ela e sua família reproduziam a existência material que acabaram por promover rupturas em sua visão de mundo:

"Isso aí era num pedacinho de terra, que, às vezes, eles cediam pra gente plantar. E aí, foi indo, foi indo ... o fazendeiro morreu. [...] E aí teve aquele negócio de inventário. Aí, reparte terra daqui, reparte terra dali, aí foi ficando mais difícil, porque um dos filhos lá, aí falava assim que não queria mais gente trabalhando na terra deles, porque diziam eles que tinha uma lei que, se a gente ficasse muito tempo ali, naquele 
pedacinho que a gente morava ... porque a gente plantava fruta também, tudo que aparecia a gente comia e ia lá e plantava a semente. Eles falavam assim que se a gente fosse recorrer pra Justiça ... só que a gente não sabia nada disso, sabe. Se a gente fosse recorrer pra Justiça, a Justiça ia dar aquele pedaço de terra pra gente. Então eles foram espertos, acharam assim que se cada um daqueles colonos ali que tivesse um pedaço de terra ia acabar com a fazenda deles. Aí eles não quiseram mais. [...] Aí eu decidi que não era isso que eu queria pra mim, não queria passar o resto da minha vida morando em cima de um pedaço de terra dos outros, que a qualquer momento eles podiam pegar e jogar a gente dali pra fora. Eu pensei mais no futuro dos meus filhos. Falei: 'Não é isso que eu quero para os meus filhos.'[...] Aí foi quando a gente pegou ... lá na roça, vende um porco, vende uma galinha, junta um dinheirinho daqui, outro dali, pelo menos pra pagar a passagem, e viemos praqui."

Apoiada nessa experiência de vida, já na cidade, Rute pôde cotejar os recursos de sobrevivência nos dois ambientes e fazer uma avaliação do acerto ou do erro de sua decisão. No confronto, Rute chegou à conclusão de que a vida no meio urbano é menos dura que a vida no meio rural, na roça:

"Porque era uma vida muito sofrida, porque se a gente trabalhasse, plantasse, tinha pra comer. Se a gente não corresse atrás, não tinha. Certo que aqui também tem que correr atrás, mas é um pouco mais fácil. Tem o médico pra você ir, tem um dentista. Dava uma dor de dente, alguma coisa assim, era remédio de mato em cima, remédio de mato ... até aquilo passar. Âs vezes a pessoa ficava um mês, quase um mês, sentindo dor de dente. Os partos. O parto da minha mãe, eu e meus irmãos nascemos todos em casa; a mãe do meu marido, os filhos dela nasceram todos em casa. Quer dizer, não tomava uma vacina. Eu nunca tomei uma vacina. Só mesmo quanto eu fui ganhar, fui pra ter eles, que eu tomei uma vacina antitetânica. Mas eu não tenho marca nenhuma no corpo de que tomei uma vacina, igual meus filhos têm. São vacinados e essas coisas assim.”

Nesse contexto, a escola, na cidade, é parte integrante de uma realidade mais amena que a vivida anteriormente por ela, e que ela valoriza por conhecer as dificuldades pelas quais passou. No que se refere às festividades que a escola realiza, por exemplo, Rute se esforça para que seus filhos estejam presentes em todas elas, mesmo que isso implique custos adicionais com roupa e calçado:

“Agora teve desfile, ela foi. Só quando é assim, marca uma festinha junina ou outra festinha que precise de comprar roupa e calçado, alguma coisa assim, que marcam muito em cima da hora, assim... se não der, eu não deixo, não. Igual daquela vez do João, que você estava lá também, eu deixei ir porque eles avisaram antes, aí deu pra mim ir arrumar ele, botar roupinha nele, tudo direitinho. Mas aí, se avisarem ... principalmente para quem é mais pobre, não dá pra pegar e fazer o negócio ... porque a gente tem os compromissos já da gente, né. Aí, pegar e ficar fazendo mais compra? Aí 
não dá. Mas sempre que é possível, eu gosto que eles participem, eles sempre participaram."

Mas é no que se refere à merenda fornecida pela escola que o valor que Rute dá a esta mais sobressai. Por saber o que significa estudar em uma escola rural, descurada pelos poderes públicos, e, talvez, por saber o significado de ter de cuidar daquilo que vai servir de alimento para ela e para sua família - seja o milho para fazer a fubá, seja a cana para se obter o açúcar, seja a galinha, seja o porco - Rute aprecia bastante a merenda que é servida na Altino Malafaia, independentemente do julgamento de sua qualidade. Quando, na entrevista, lhe perguntava se tinha alguma queixa em relação à escola, e Joana, sua filha, interveio para reclamar da qualidade da merenda, Rute prontamente a contestou:

A merenda não, merenda, à vista de onde que eu estudava, quando eu comecei a estudar, não tinha merenda, merenda, a gente pegava um ovinho e fazia uma farofinha lá ...

E em outra ocasião, mais uma vez, Rute voltará a enfatizar o valor da merenda, ao mencionar uma brincadeira que fez com o filho que, visando subestimar o reparo que este fizera à consistência do macarrão, pretendia fazê-lo atentar, de maneira indireta, para a importância de se receber alimentação:

"Outro dia, o meu menino falou: 'Mãe, o macarrão é muito duro, o macarrão fica agarrando no dente da gente.' Eu ainda brinquei com ele: 'O seu macarrão é 'al dente', é o verdadeiro macarrão 'al dente', não tem macarrão 'al dente'?'

Quando lhe perguntei sobre os problemas da escola, Rute não se mostrou incomodada por eles, não se detendo em salientar qualquer uma das possíveis deficiências institucionais, embora declarasse ter apenas uma única reclamação, a ociosidade dos alunos na ausência do professor: 
"Não sei se é coisa do Prefeito, do Governo, não sei o que é, porque tem o negócio de tempo vago, o professor falta, não sei o que acontece, e eles [os alunos] ficam lá de bobeira. Eu acho que devia de ter uma estagiária, principalmente pra agora, pra quinta série. Antes não. Eu acho que tinha que ter uma estagiária pra ficar ensinando a eles."

Assim, pode-se presumir que foram as condições de vida de Rute - as dificuldades que enfrentou no passado - que determinam a avaliação positiva que faz de sua situação no presente e que se estende à escola que os filhos freqüentam. Os aspectos positivos da escola e a valorização desta, portanto, inserem-se em um contexto em que a realidade urbana é comparativamente menos árdua que a vivida anteriormente no meio rural, e em que a participação é vista como uma oportunidade de aproveitamento das vantagens da vida na cidade.

À semelhança de Rute, Rosa também teve uma vida de muitas dificuldades. Rosa, segundo sua própria expressão, "nascida e criada na Paraíba”, é uma mulher que chama logo a atenção por sua fala, com forte sotaque nordestino, e pela expressão de seu rosto, sempre muito risonha. Rosa veio casada para o Rio de Janeiro, onde teve os filhos Emília, Emerson e Edivaldo. Quando estava grávida do último filho, seu marido morreu, atropelado na rodovia federal, o que mudou completamente sua perspectiva de vida:

\footnotetext{
"Eu morava até de caseira, onde tem um sitinho de coqueiro ali em frente, daquele lado ali, onde tem uns pés de coqueiro... Eu morava de caseiro ali. Aí, eu queria ir embora pro norte, mas a dona da casa não deixou eu ir. Essa foi uma mãe pra mim. [...] Eu queria ir embora e ela: 'Não, Rosa, você não vai embora pro norte, não. Você disse que seu pai é pobre, você não tem mãe, o que você vai buscar lá no norte? Te garanto que aqui você não vai morrer de fome, nem você e nem seus filhos."
}

De acordo com Rosa, foi a dona da casa que a sustentou até que ela conseguisse receber a pensão do marido. E, depois, à medida que as crianças foram crescendo, Rosa começou a trabalhar para complementar a pensão: "Comecei vendendo queijo: [...] 
comprava queijo e vendia." Por ser muito trabalhadeira, lutou pela sua sobrevivência e de seus filhos de várias maneiras:

"Era vendendo queijo, era lavando roupa pra fora, às vezes eu pegava lote dos outros pra capinar, pegava roupa pra lavar, roupa pra passar do pessoal. Sempre trabalhei, sempre fui assim. E lá na roça, eu trabalhava na roça mesmo, lá no norte. [...] Depois eu deixei o queijo e fui trabalhar em casa de família. Trabalhei nessa rua ali que tem o hotel, ali."

Ainda hoje, mesmo tendo emprego assegurado em casa de família, Rosa sempre está procurando um serviço para fazer:

"É. Sempre pego um bico. Tanto que agora eu estava de férias e eu estava trabalhando lá em Muriqui, num restaurante. Agora que eu parei."

Na condição de mulher chefe de família, Rosa, como tantas outras brasileiras, precisa dedicar-se, diariamente, aos afazeres domésticos, além de ter de dar conta dos problemas de casa que eventualmente surgem, tais como: consertos, vazamentos, etc. Conciliar todas essas atividades exige, muitas vezes, que se abra mão de um ganho extra, como o que ela vinha obtendo no restaurante:

"Porque a gente está fazendo aí o muro, consertando, esse menino que está comigo está fazendo. E ele só tem tempo final de semana. Final de semana eu estava lá pra cima [em Muriqui], ele achava chato vim pra cá trabalhar aqui sozinho ... [...] Aí eu disse: 'Quer saber? Eu vou largar lá em cima e vou ficar em casa, pelo menos final de semana, que ele vai terminando de fazer meu serviço.' E outra coisa, eu estava ficando cansada, trabalhar a semana toda, chegava em casa, lá só tinha horário pra pegar, não tinha horário pra largar. Quer dizer, eu chegava em casa, tinha roupa pra lavar, tinha comida pra fazer, casa pra arrumar. Eu disse: ‘Ah, não dá não!' Aí peguei e saí de lá.”

Há alguns anos, a esses afazeres também se juntava o acompanhamento escolar dos filhos, ainda pequenos, que freqüentavam a Altino Malafaia ${ }^{28}$. Segundo Rosa, Emília nunca lhe deu trabalho na escola, mas de Emerson e de Edivaldo sempre teve reclamações. Emerson tinha um problema de audição, descoberto tardiamente quando

\footnotetext{
${ }^{28}$ Dos três filhos, apenas o mais novo, Edivaldo, ainda freqüenta essa escola, cursando a sétima série.
} 
este já havia levado cinco anos para fazer o CA (a Classe de Alfabetização) e a primeira série do ensino fundamental:

"Eu chegava lá [na escola] e todo dia tinha reclamação que ele não fazia o dever. Um dia se queixava de uma coisa, no outro de outra, dizia que tava com dor de cabeça ou dizia que estava com dor no estômago, outro dia que estava com dor de barriga, só vivia cheio de problemas. Coitado do Emerson. Eu sempre achava que era preguiça. Quando foi um dia, dona Dalva [a dona da casa em que Rosa era caseira] levou ... nas férias ele sempre passava lá no Rio com ela. Chegou lá, dona Dalva levou ele num médico de vista. E aí não tinha nada na vista. Aí levou num otorrino, médico de ouvido. Aí descobriu, o menino tinha um problema de ouvido. Por isso que ele chorava tanto quando era novinho e eu não sabia o que o moleque tinha, tinha um problema de ouvido desde quando nasceu. [...] Por isso que a professora falava comigo que falava com ele, e ele só fazia assim: 'Hum? Hã?' A professora: 'Emerson, você não escutou o que eu falei?' O Emerson: 'Hum.' Quer dizer, ele nem escutava e falava 'Hum'.'

Já Edivaldo recusava-se a ir para a escola e não gostava da professora:

"Porque eu batia nele ... ele não queria ir pro colégio, aí pegava e batia. Eu levava e buscava, levava e buscava no colégio. Eles eram pequenininhos, né. Aí eu levava ele no colégio [...] e chegava lá no colégio a professora falava pra mim que ele brigava com os outros alunos, não queria fazer o dever. Ela chamava a atenção dele e ele xingava. Teve um dia que xingou a professora de capeta, minha filha! Lá na sala. [...] Olha, era uma luta! Todo dia eu ia no colégio, e ela tinha uma reclamação dele."

Embora Rosa tivesse reclamações freqüentes de Emerson e de Edivaldo, em nenhum momento ela punha em dúvida a justeza delas. Assim é que, no caso de Emerson, ela chega a reconhecer seu equívoco: "Coitado do Emerson. Eu achava que era preguiça." Para Rosa, o desconforto do filho na escola - expresso nas dores que Emerson dizia sentir - era pura preguiça, e, sendo preguiça, justificava as reclamações que a professora dele fazia. No que se refere à escola, Rosa não questionava a capacidade profissional da professora que se queixara de Emerson por este não ter feito o dever, ainda que o aluno desse mostras não apenas de desconforto físico, mas até mesmo de deficiência auditiva, e que houvesse repetido vezes seguidas as mesmas séries. 
No caso de Edivaldo, Rosa percebeu que, na passagem da primeira para a segunda série, a troca de turno e de professora desagradou o filho, que passou a não querer ir para a escola, e que quando ia, obrigado pela mãe, mostrava atitudes de revolta, recusando-se a fazer o dever, brigando com os colegas, etc. Mas, ainda assim, Rosa não se perguntava os motivos pelos quais Edivaldo não havia gostado de mudar de turno e também de professora, a ponto de xingá-la.

No entendimento de Rosa, o modo como o filho Edivaldo, aluno, se colocava perante a professora condicionava o modo como esta o recebia:

"Ele não gostava dela. Pra você vê, era assim uma coisa que ele não gostava dela, e ela acabou também se afastando dele. Porque se a criança é rebelde ... eu acho assim ... se o aluno é rebelde e é malcriado, a professora não vai gostar de um aluno desse. E a professora se zangava com ele e ele se zangava com a professora."

Para Rosa, a escola que os filhos freqüentavam era expressão das oportunidades que a providência lhe havia dado para continuar a viver em uma localidade simultaneamente estranha e promissora, tal como os inúmeros serviços que ela havia arrumado durante sua permanência em Itaguaí. Desse modo, se a condição de sobrevivência era adaptar-se aos sucessivos patrões - e não afrontá-los - também o era adaptar-se à autoridade escolar, representada mais diretamente pelas professoras dos filhos. E foi isso o que ela expressou a Edivaldo, quando este lhe dissera que "a professora era ruim":

"Ah, Edivaldo, a professora quem faz é a gente, é igual a uma patroa, um patrão, é a gente que faz. A gente vai levando eles, conforme eles levam a gente."

Do ponto de vista pessoal, a escola ainda representa para Rosa a oportunidade de uma realização íntima. Na roça, na Paraíba, seu pai nunca lhe havia permitido estudar - nem às suas irmãs - por entender que não havia necessidade de a mulher estudar. Assim, quando Rosa pôde freqüentar, aos 38 anos, a própria escola dos filhos, esse foi um 
acontecimento muito feliz em sua vida. Ao longo do período em que realizei o trabalho de campo na Altino Malafaia, Rosa era, dentre os alunos, a mais entusiasmada em participar do desfile cívico anual. Exibia, mesmo, em seu rosto uma expressão de orgulho, a que atribuí à satisfação íntima por estar freqüentando escola e, em decorrência, por poder mostrar publicamente a sua condição de aluna. Portanto, quando lhe perguntei o que achara de ter participado do desfile, já previa que Rosa deixaria extravasar toda a sua emoção:

\begin{abstract}
"Adorei! Desde sempre que eu comecei a estudar, desde o primeiro ano, tem três anos que eu estudo lá, todos os três anos eu participei do desfile. Desfilei todos eles. Primeiro ano, foi aquela camisa que estava escrito atrás 'Mãos à obra'. O segundo ano, foi a camisa amarela. E o terceiro ano, foi esse ano que passou, foi uma camisa representando o ... que o tema lá do desfile era 'Brasil, 500 anos'. Eu não sei se a gente estava representando ... se era os gaúchos ou uma outra coisa lá, não me lembro, só sei que a nossa camisa tinha um mapa aqui na frente. Até, da nossa turma, da nossa sala, só foram dois alunos. Estava certo de ir cinco alunos desfilar da nossa turma, porque de cada turma ia um pouco, mas a turma ficou certo de ir cinco. Chegou no dia, só foi dois. Eu e uma outra aluna."
\end{abstract}

Desse modo, pode-se presumir que são as condições de vida de Rosa - a incerteza quanto ao futuro de uma viúva e de seus três filhos em uma localidade estranha, e a labuta diária como recurso para se dominar a incerteza - que determinaram uma estratégia de vida em que a superação das adversidades toma a forma de uma adaptação às circunstâncias. Por isso, o esforço para que os filhos sejam aceitos pela instituição escolar representa o próprio sucesso de Rosa na luta pela sobrevivência, a que se junta sua alegria particular de freqüentar escola.

\title{
2.3.6. A participação enquanto procura do reconhecimento público do trabalho doméstico e enquanto procura de confirmação da identidade feminina: Neusa e Rosa
}

Tentativas de participação de mães de alunos na escola já foram registradas em estudos sobre gestão escolar assinalando a interferência das questões de gênero na 
democratização da gestão. Maria Malta Campos (1982), em pesquisa realizada em dois bairros populares da cidade de São Paulo, observou que, embora as mães se propusessem a fiscalizar o funcionamento e a conservação do prédio escolar e, ainda, as condições de preparo e distribuição da merenda, estas não se sentiam à vontade em dar assistência aos filhos nos deveres escolares, tal como a escola lhes prescrevia. Ainda que Maria Campos não houvesse tratado especificamente do gênero como uma variável distinta em sua análise - mas houvesse destacado tratar-se da participação de mães de alunos na escola - , estudo mais recente, ao chamar a atenção para a extensão das chamadas práticas domésticas femininas na atividade docente, ressalta o trabalho doméstico como um tipo de prática feminina que condiciona social e culturalmente a mulher (Piza, 1994), o que contribui para justificar a preferência das mães por aquela forma de participação registrada na pesquisa de Campos.

Em estudo no qual procura avaliar o que chamou de "contaminação de práticas" - a extensão das práticas domésticas femininas para a esfera do trabalho docente - , que intervém no comportamento profissional da professora, Edith Piza (1994) aponta aspectos importantes do trabalho doméstico que não são muito explorados na literatura sobre o tema. Assim, Piza mostra que, embora o trabalho doméstico seja social e culturalmente compreendido como aquele que define as atividades ditas femininas, e, portanto, relegado ao âmbito privado, por oposição ao público, há no trabalho doméstico ambas as dimensões: a privada e a pública.

Por um lado, Piza constata que a dona-de-casa nos centros urbanos não vive encerrada em seu lar, percorrendo os espaços públicos - pagando contas, fazendo compras, representando a família - , exercendo, portanto, uma parcela da atividade doméstica fora 
de casa, e garantindo, dessa forma, a rotina da vida da família. Por outro lado, as próprias atividades domésticas exercidas no interior do lar revelam essa dupla dimensão: uma dimensão privada, que atende às necessidades imediatas dos membros da família e também às exigências de natureza afetiva, representada, por exemplo, pelas atividades de lavar, passar, limpar, cozinhar; e uma dimensão pública que decorre da qualidade do trabalho que a dona-de-casa executa, e que, através do testemunho de vizinhos, amigos e parentes que visitam a casa, projeta a imagem da mulher para fora do lar.

O primeiro contato com Neusa (mãe de Lúcia, Tiago e Roberto) deu-se de forma ocasional, quando esta se dirigia à inspetora de alunos da Altino Malafaia para se queixar de D.Iacy, professora de Lúcia, que raramente a convidava para participar dos grupos que se apresentavam nos eventos da escola. O que, a princípio, parecia um simples pedido de mãe para que a filha se fizesse mais presente nas festividades da escola logo evoluiu para um pedido de reconhecimento do valor da própria mãe, ao ouvir a justificativa que Neusa dava para a presença mais marcante de Lúcia: ela, Neusa, podia não ter estudo, mas sabia costurar muito bem. Assim, se Lúcia fosse convidada por Iacy, a mãe poderia fazer roupas variadas para a filha, de acordo com o tipo de festividade.

Quando entrevistei Neusa em sua casa, esta, ao final do encontro, mostrou-me fotografias em que se registravam os festejos da família: seu próprio casamento, aniversários, comemorações diversas. Nas fotos, a habilidade da dona-de-casa estava ressaltada: o bolo, os doces, os arranjos de mesa e de parede e as roupas dos filhos, tudo havia sido feito por Neusa. 
Do mesmo modo, nas fotografias em que se registravam festividades na escola envolvendo sua filha Lúcia, a roupa que esta trajava em diferentes ocasiões - formatura no CA, festa junina, Festa da Primavera, etc. - havia sido feita por Neusa, como ela mesma fazia questão de mencionar. E mais ainda, em um evento na Pré-Escola que seu filho Tiago freqüentava - também gravado em fotografias -, as roupas de todas as crianças da turma do filho - cerca de vinte - haviam sido confeccionadas por Neusa, a partir do tecido que a diretora da escola havia fornecido a ela.

Desse modo, a solicitação que Neusa fazia para que Lúcia se apresentasse com maior freqüência nas festas da escola situava-se em um contexto em que determinada atividade doméstica da mãe - costurar - necessitava ser valorizada como uma forma de projeção da dona-de-casa para além do lar. Nesse sentido, a busca de Neusa por um espaço (público) no qual a qualidade do trabalho doméstico (privado) pudesse ser reconhecida pode ser interpretada, por um lado, como um desejo de valorização da mulher externamente ao âmbito da família e, por outro, como uma demanda de participação da própria mãe na instituição escolar, em que a falta de estudo não se constitui obstáculo, porque essa falta é compensada por uma atuação através do emprego de uma competência da mulher atribuída ao trabalho doméstico: saber costurar.

Se a mulher Neusa precisa tomar a iniciativa de procurar a esfera do público, representada pela escola, para ver valorizada uma atividade que é realizada no círculo restrito da família, portanto, na esfera do privado, apostando na qualidade do trabalho que desenvolve em casa, outra é a situação da mulher Rosa, que, na condição de 
(orgulhosa) aluna do Projeto Educação de Jovens e Adultos, e freqüentadora assídua dos eventos da escola, já usufrui dos benefícios do espaço público no qual sua habilidade como cozinheira pode ser revelada. Assim, por ocasião de festejos escolares, quando é solicitado aos alunos do Projeto Educação de Jovens e Adultos que colabore com um prato de salgado ou de doce, Rosa prontamente se dispõe a ajudar:

\begin{abstract}
"Sempre participo de tudo. Teve festinha eu tô participando: festa de fim de ano, festa do folclore, festa junina, todas elas eu tô lá. Quando tem que levar alguma coisa, quando eles pedem prenda pra botar nas barracas, eu dou, mando os meninos levar. Quando pede prato de salgado ou de doce ... Igual a uma festa que teve, não sei se foi festa junina ou o que foi, teve uma festa e me pediram pra levar um prato de doce. Eu fiz um bolo gelado, lindo, grandão. Olha, só dava o meu bolo, vendeu rapidinho. Foi até num domingo a festa, na mesma hora saiu. A professora partiu, a professora Cássia, na barraca ... ela ficou na barraca também. Até a dona Jane [Coordenadora do turno da noite] e a dona Neide [Diretora da escola], eu acho, que levou do bolo. Todo mundo comprava, foi o primeiro a ser vendido, saiu num instantinho. E eu fiz grandão, um bolão redondo. Eu fiz com uma cobertura de coco, botei leite condensado, fiz um mingau e botei leite condensado com creme de leite, maisena. Fiz um mingau, fiz o recheio, botei. Fiz dois bolos, um em cima do outro. Aí botei por cima coco ralado. Ficou foi gostoso. Vendeu rapidinho."
\end{abstract}

Como se pode notar, Rosa faz questão de descrever o bolo e de mencionar os ingredientes com os quais o confeccionou, resgatando - pela via do relato - a imagem da dona-de-casa habilidosa que faz um bolo tão gostoso que, tão logo é posto à venda, é consumido rapidamente.

O que se destaca em ambas as situações é que tanto a participação de Neusa - a mãe quanto a de Rosa - a aluna - correspondem a uma necessidade de valorização do trabalho que é social e culturalmente atribuído às mulheres, o trabalho doméstico. No caso de Neusa, o trabalho e os gastos na confecção de roupas para que a filha participe dos eventos escolares são minimizados porque seriam compensados pelo reconhecimento em um ambiente mais amplo (a escola) de uma atividade que é desenvolvida pela mulher em um ambiente mais restrito (a casa). No caso de Rosa, se o 
trabalho, sob a forma de confecção do bolo, pode ser admitido e incentivado pela escola como um modo de participação, da perspectiva da aluna, esse trabalho pode ser um meio de projeção da mulher para além do âmbito do lar, ainda que os gastos na confecção do bolo, assumidos de maneira privada, se revertam em dinheiro para manutenção da escola, uma instituição pública.

Desse modo, pode-se admitir a hipótese de que a contrapartida de uma forma de participação que, via de regra, é solicitada às mães nas escolas que os filhos frequientam - a doação de um prato de salgado ou de doce para ser vendido nas festas - pode ser a oportunidade de a mulher obter um ganho - não financeiro, evidentemente - que advém da valorização de um tipo de atividade tradicionalmente atribuído a ela, no caso, saber cozinhar. O que a mulher providencialmente ganha, então, é a confirmação da identidade feminina.

\subsubsection{A particípação no contexto de uma ética díplice - $\sigma$ homem como cidadão e o homem como pessoa: Nice e SewCampos}

Um aspecto particular da escola pesquisada é o acesso franqueado dos pais e mães de alunos às suas dependências e à sua administração. Alguns destes faziam-se presentes de modo tão assíduo e tão marcante na unidade escolar que se tornavam conhecidos pelos professores e pelos demais funcionários da escola. É o caso de Nice e de Seu Campos. 
Uma série de circunstâncias contribuíram para que Nice se fizesse conhecida pelo pessoal escolar: o fato de ter tido cinco dos seus sete filhos matriculados na escola ${ }^{29}, \mathrm{o}$ fato de ter dois netos estudando na escola, e o fato de ela mesma, há três anos, ser aluna, dentro do Projeto Educação de Jovens e Adultos. No entanto, essas circunstâncias contribuíram também para que Nice conhecesse as atividades e os serviços desenvolvidos na unidade escolar, bem como o seu cotidiano, para além do simples contato com esta. Assim, Nice ficou marcada por ter sido a primeira pessoa a se utilizar do atendimento dentário oferecido na própria escola, uma vez que teve conhecimento prévio do serviço e que se dispôs a chegar cedo no dia em que o serviço começou a funcionar. No que se refere aos eventos, Nice é assídua freqüentadora deles, pois faz questão de que a filha participe de todos os eventos que a escola promove: festa junina, dia das mães, festa da primavera, desfile cívico escolar, dia de ação de graças, etc., participando ela mesma, como aluna, de algumas festividades. No que diz respeito ao dia-a-dia escolar, Nice sabe de tudo o que acontece na escola, por sua presença quase que diária, seja de dia como mãe e avó, seja à noite como aluna.

Desse modo, favorecida pelas circunstâncias, Nice tem a oportunidade de acompanhar o cotidiano da escola, mas seus posicionamentos, ou são elogios, ou, surpreendentemente, quando são reclamações, não são tão ressaltadas a ponto de poderem chegar a constituir reivindicações.

Assim, quando lhe pergunto se tem alguma crítica a fazer à escola, Nice, de pronto, me responde que não, que não tem nenhuma queixa da escola, que "o ensino lá é melhor que uma escola particular" e que "Dona Neide [a diretora] é ótima", mencionando

\footnotetext{
${ }^{29}$ Dos cinco filhos de Nice matriculados na Altino Malafaia, apenas Maria ainda estuda na escola, cursando a $5^{\text {a }}$ série.
} 
apenas que "algumas professoras da manhã ficam mais na porta que dentro da sala de aula".

À medida que a entrevista se desenvolve pode-se perceber a razão pela qual, embora Nice seja uma observadora bastante atenta e faça inúmeros reparos ao que ocorre no interior da escola, suas reclamações não se consolidam e não se alçam à condição de reivindicações. É que Nice resolve todas as suas dificuldades pessoalmente com a diretora, o que minimiza o teor das reclamações, ainda que estas envolvam seus interesses mais imediatos.

É assim, por exemplo, que se pode compreender por que a avaliação de Nice de que "Marisa [sua neta] nunca teve professora boa" não recebe de sua parte repulsa imediata, limitando-se a ser um mero reconhecimento. A corroborar esta interpretação se junta o relato de um acontecimento que envolveu Marisa, filha de seu filho Chico, na escola. Quando Marisa caiu e machucou o braço, os alunos estavam sozinhos em sala pois a professora havia se ausentado momentaneamente. Assim que o pai soube, revoltou-se, provocando a intervenção de Nice, que orientou o filho a proceder como ela sempre procedia: falando com a diretora para pedir providências. No caso em questão, porque Chico "não queria arrumar problema com a professora porque [esta] era nova", a providência pedida foi ter "uma professora com mais experiência", no que foi atendido. Nas palavras de Chico:

"Mas a gente conversou com a Neide, a Neide resolveu a situação toda, e nós pedimos pra Neide, e a Neide trocou ela de professora..."

A influência das relações pessoais na escola tem sido objeto de certos estudos que têm a experiência social como núcleo de sua investigação. Em Les lycéens, por exemplo, 
François Dubet (1991) toma a experiência social dos estudantes do liceu ${ }^{30}$ como uma atividade cognitiva que dá significado a esse nível escolar, na medida em que a vida no liceu é objeto da experiência cotidiana de seus estudantes.

Dubet mostra que a experiência educativa, enquanto uma dimensão da experiência escolar que envolve os estudantes, implica a formação de um sujeito - o próprio estudante - na qual as relações pessoais desempenham um papel fundamental. Desse modo, a ligação dos estudantes com o conhecimento passa por uma relação social entre os alunos e o professor, da qual aqueles extraem o significado subjetivo do ensino, que concorre para os formar e para os transformar, para além da simples assimilação do conteúdo da disciplina. A esse aspecto se junta outro, que complementa a experiência educativa do estudante e que participa também de sua formação, envolvendo as relações que se estabelecem nos grupos de estudantes arranjados em torno de interesses diversos.

A interferência das relações pessoais na escola tem sido, ainda, objeto de outros estudos que destacam sua centralidade na atividade de ensinar enquanto esta é um trabalho com pessoas, em que o professor é concebido como um sujeito, interagindo com alunos, concebidos também como sujeitos. Assim, por exemplo, Marília Carvalho (1999) compreende que, "para além de uma abordagem intelectualista do ensino, que apreende os processos da sala de aula como mera transmissão - ou não - de saberes", o trabalho docente envolve "dimensões existenciais e afetivas [que] não podem ser desconhecidas". (Carvalho, 1999, p.1) Desse modo, aspectos relacionais do trabalho docente junto a crianças, "tais como o envolvimento afetivo, a atenção a problemas

\footnotetext{
${ }^{30} \mathrm{O}$ liceu, na França, corresponde, no sistema educacional brasileiro, ao ensino médio.
} 
familiares e sociais" e a saúde e a higiene das crianças são entendidas como práticas nas quais “o cuidado está incorporado como valor e referencial”. (Carvalho, 1999, Resumo)

Embora se trate aqui, na perspectiva de Dubet e de Carvalho, de relações pessoais inscritas, respectivamente, na experiência educativa do estudante e na relação do professor ou da professora com seus alunos no âmbito da atividade docente, pode-se olhar, ainda, para a incidência das chamadas relações pessoais na escola como expressão de uma ética singular que, no terreno da instituição escola, dá uma nova orientação ao ordenamento social.

Quem dá o fio condutor para essa outra perspectiva é Roberto DaMatta (1997) que constata a existência de éticas diferenciadas na sociedade brasileira, onde a relação desempenha um papel fundamental, ao lado da noção de cidadania, na concepção e na dinâmica da ordem social.

DaMatta mostra que, a par dos vínculos de caráter jurídico-político-moral que gravam a noção de cidadania, esta também abarca uma dimensão sociológica básica, já que ser cidadão implica assumir um papel social, que, além de ser institucionalizado em sociedade, ainda precisa ser construído na esfera moral. Assim, assumir o papel social de cidadão significa reconhecer uma identidade social que nivela e iguala todos os homens em torno dos direitos e dos deveres para com uma entidade chamada nação, e que, por nivelar e igualar, torna o cidadão uma entidade abstrata e universal.

No cotidiano da vida em sociedade, no entanto, a essa entidade de caráter abstrato e universal - que toma os homens como indivíduos perante as leis - , vem se juntar outra 
de natureza concreta e particular - que toma os homens como pessoas diante das mesmas leis. Essa duplicidade é permitida pela incidência da relação, que, produto de um ritual de reconhecimento, funciona como uma espécie de compensação social, possibilitando hierarquizar e discriminar a totalidade social: pela relação deixo de lado o isolamento universal a que condena a condição de cidadão e me inscrevo em uma rede de afiliações, representada pela família, pelos amigos, pelo partido político, etc.

Desse modo, revelar a condição de ser filho de fulano, ser amigo de beltrano, ou ser membro importante de um partido $x$ personaliza as situações nas quais a igualdade é um princípio regulador do código político adotado pela sociedade, mas, ao mesmo tempo, e por isso mesmo, o reconhece em sua característica ideal e normativa que torna o cidadão um homem com direitos iguais aos de todos os outros homens.

A conclusão de DaMatta é que essa ética dúplice, fornecendo fontes diferenciadas de pertencimento a uma mesma realidade social, possibilita a complementaridade das experiências, na medida em que "as experiências negativas de um lado possam transformar-se em experiências positivas do outro.” (DaMatta, 1997, p.93)

Se a prática social da mãe, avó e aluna Nice em relação à escola pode enquadrar-se na prática cotidiana da vida em sociedade no Brasil, baseada nas mediações adscritas à relação - exemplificada pelo modo de resolução dos problemas através de sua relação pessoal com a diretora Neide - a prática social do pai Seu Campos mostra outra dimensão, a dimensão da ética pública, embora inclua, também, as relações pessoais como alternativa de solução dos problemas. 
Seu Campos conhece a localidade onde está situada a escola e onde mora, há mais de quarenta anos, quando trabalhava como corretor. Naquela ocasião, chegou a comprar um lote de terreno, pelo qual foi indenizado mais tarde em decorrência da instalação de uma subsidiária da Eletrobrás no local. Após o falecimento de sua mulher, com a realização de um novo matrimônio, e diante da impossibilidade de continuar residindo na cidade do Rio de Janeiro, Seu Campos teve a oportunidade de voltar a Itaguaí, ao adquirir, em leilão da Caixa Econômica Federal, a casa onde mora há treze anos.

Em virtude de seu engajamento nos problemas do bairro, Seu Campos observa que a atuação do poder público é falha - "a assistência pública é negativa” - e que o procedimento corriqueiro da população, em face da ausência de um sistema de esgoto sanitário, é engajar-se com políticos no intuito de pedir manilhas que os próprios moradores, em mutirão, dispõem para providenciar a canalização dos resíduos orgânicos em direção ao curso d'água mais próximo. Ele mesmo, tempos atrás, utilizou-se de uma relação de amizade com o então Prefeito para solicitar manilhas para a sua rua, o que contribuiu para que a incipiente Associação de Moradores obtivesse sua primeira conquista:

\footnotetext{
"Aí de manhã, eu fui direto à Prefeitura. Chegando lá, subi. [...] Estava lá conversando, conversando: 'Mas o senhor pretendia o quê?' [pergunta o Prefeito] Eu disse: 'Eu queria fazer uma coisa que é serviço da Prefeitura, mas como a Prefeitura não tem condições de fazer agora, não tem homens ou qualquer coisa, eu, como vice-presidente da associação, eu quero assumir essa responsabilidade. Mas quero as manilhas.' Ele: 'Quantas manilhas você quer?' Eu dei o total. Ele chamou um camarada lá, que era cupincha dele, que era sub-encarregado de obras ou qualquer coisa assim, o Manoel: 'Manoel, toma nota do endereço do Seu Campos aí. Vai naquela fábrica de manilha, apanha essa quantidade de manilhas, mas entrega na casa do Seu Campos, não entrega em outro lugar.' Eu ainda fiquei conversando com ele um pouco, o Manoel saiu. Quando eu peguei o ônibus e saltei aqui na esquina, o caminhão já estava descarregando as manilhas aqui na minha porta. Aí juntou o pessoal todo, começamos a rasgar a rua e colocamos as manilhas."
} 
Em outras oportunidades, Seu Campos também se utiliza da rede de relações para fazer reclamações e reivindicações na emissora de rádio local, tal como aconteceu em um período prolongado de falta de água e na solução de um problema de uma vizinha que teve o valão que escoava o esgoto de sua casa aterrado por outro vizinho.

Esse mesmo envolvimento que Seu Campos têm em relação aos problemas coletivos e particulares que afetam o bairro onde mora, ele o tem com a escola onde estuda a filha Paula e onde estudava a outra filha Júlia até 1999. A par de ser membro da Associação Escola-Comunidade ${ }^{31}$, representando o segmento de pais de alunos, Seu Campos atua, ainda, no interesse da escola quando, por exemplo, há pouco tempo, insistia com o atual diretor da Altino Malafaia para que ambos instassem junto à Prefeitura a colocação de placas de trânsito indicando o limite de velocidade nas imediações da unidade escolar:

"Eu brigando lá com o Celso [diretor da escola]... Forçar junto à Prefeitura pra botar placas ali de quarenta quilômetros. Botaram e agora tem um policial ali, na frente da escola."

Portanto, paralelamente à utilização da rede de relações na resolução dos problemas, Seu Campos mostra, ainda, reconhecer a res pública, o bem comum, quando se mobiliza em favor do interesse coletivo, representado, no caso, pelos alunos e seus pais. Também no exercício de sua função como membro da Associação Escola-Comunidade, Seu Campos mostra ter respeito pela coisa pública, quando, por exemplo, fiscaliza os gastos da diretora, em que pese sua relação de amizade com Neide:

"A dona Neide é muito minuciosa, tudo ela quer fazer pesquisa de preço, ela pergunta, ela traz comprovante de tudo. E eu quero ver tudo direitinho. Um dia desses, essa última prestação de contas que ela fez, o Rubem [cunhado de Neide e político conhecido na região] estava lá com ela. Aí eu comecei, aí o Rubem: 'Ô Campos, precisa fiscalizar

\footnotetext{
${ }^{31}$ Como já dito anteriormente, a Associação Escola-Comunidade foi criada na escola em questão para ser a Unidade Executora do Programa de Manutenção e Desenvolvimento do Ensino Fundamental que repassa, anualmente, dinheiro para custeio e manutenção das atividades das escolas públicas.
} 
tanto?' Eu disse: 'Precisar, não precisa, mas é obrigação e eu tenho que fazer.' Precisar não precisa, porque eu sei quem é a dona Neide. Mas tem que fazer, aí eu fiscalizo tudo direitinho."

No mesmo sentido de salvaguarda do bem público orienta-se sua crítica ao uso do espaço físico da escola para festejos de particulares, já que as despesas resultantes de gastos ou de estragos serão arcadas pela instituição, podendo ser debitadas da verba oriunda do Programa de Manutenção e Desenvolvimento do Ensino Fundamental:

"Outra coisa, qualquer pessoa faz 15 anos aí ... festa na escola! Peraí, está em condições de fazer uma festa? Faça na sua casa. Eu fiz aqui a minha e não ficou ruim. Agora ... é na escola! Depois quebram uma cadeira, quebram isso, gastam gás... Ninguém vai repor o gás que gasta ali pra fazer o cachorro-quente, fazer os doces! É tudo lá. Nisso tudo eu meti o malho. [...] Eu disse à dona Neide: 'Infelizmente, pode não ser simpático, mas a minha função é essa."

A adoção de uma ética que se fundamenta no favor, e que discrimina favoravelmente alguém por sua relação de parentesco ou de amizade com fulano, não significa, no caso de Seu Campos, sujeição absoluta aos vínculos de lealdade pessoal. Ao ser diretamente questionado sobre os desdobramentos dos pedidos pessoais, Seu Campos revela a autonomia de quem, ciente dos aspectos positivos da rede de relações, se beneficia dela, mas não se deixa aprisionar por ela:

Pesquisadora: Seu Campos, quando o senhor procura um vereador e ele, por exemplo, consegue as coisas, ou o Prefeito, o senhor se sente assim na obrigação de ter que votar nele, ou ele fica com essa expectativa de o senhor votar nele?

Seu Campos: Eu não! Aqui, em época de eleição, a minha casa enche de político.

Pesquisadora: Eu lembro que, naquela época em que eu estive aqui, teve um que deixou um bolo assim de ... ["santinhos", pequenos panfletos que apresentam o candidato]

Seu Campos: Mas são de todos os partidos! Só tenho um voto. E eu não precisava de votar mais pela minha idade [83 anos]. Pela simpatia, eu escolho um e voto. Eu não posso votar em todos, eles têm que saber disso.

Pesquisadora: Mas quando o senhor vai e pede, como no caso do Adalberto [Prefeito de Itaguaí, a quem Seu Campos havia solicitado as manilhas] ... Ele conseguiu e tal. Ele fica esperando que o senhor vote, que o senhor faça campanha pra ele? 
Seu Campos: Ah, ele espera. Todos eles só dão ... ninguém dá uma passagem de graça sem ...

Pesquisadora: Mas eles pedem que o senhor se comprometa com isso?

Seu Campos: Não! Eu não me comprometo com ninguém, eu não! A família do Almeida [atual Prefeito de Itaguaí] toda me conhece, se dá comigo, me abraça, conversa. A família do Rubem [cunhado de Neide, adversário do atual Prefeito na última eleição] me leva pras ilhas pra passear, andar por aí ... [...] O Calixto [exPrefeito] é outro, onde me encontra fala comigo. O irmão do Calixto também vem muito aqui, o Luciano. O Júnior, filho do Gerson Magalhães [vereador] também me procura. O Romeu Pinheiro [vereador] sempre me procurou, ainda tem muita camisa aí do Romeu Pinheiro, ele queria que eu espalhasse pro pessoal.

Pesquisadora: Então a quê o senhor atribui que o senhor pede e consegue?

Seu Campos: Sei lá. Eu não sei se eles acham graça, nessa minha idade, eu ter esse espírito moleque, como eles chamam 'moleque'. Eu estou sempre rindo, sempre inventando uma piada, e então eu consigo as coisas com eles.

Em que pese a insubmissão relativa aos vínculos de lealdade pessoal expressa na independência do voto, Seu Campos orienta sua preferência eleitoral, a par da consideração pelo interesse coletivo, também pela busca de melhoria de sua situação particular, através dos possíveis melhoramentos do bairro onde mora, que um vereador ou um prefeito poderia proporcionar. É sob essa perspectiva que ele critica aqueles que vendem seu voto:

\footnotetext{
"Mas aqui, eu não sei se é a pobreza, se é a ignorância, o que é, que eu acho que uma pessoa que diz assim: 'Vou votar em Fulano? Prefiro votar em Beltrano, que vai me dar trinta reais.' Eu acho isso uma pobreza de espírito! Porque aqueles trinta reais é uma vez só. O sujeito sai dali, toma duas cervejas, acabou. Então, ao passo que se votasse certo ajudaria ao bairro dele, à cidade dele, e, conseqüentemente, melhoraria a sua situação também. Aqui, se isso melhorasse, valorizaria a minha casa. Se isso aqui está do jeito que vai, a cada dia ... Hoje eu quero vender essa casa, quero quarenta nessa casa, e ninguém dá."
}

Em resumo, tanto no caso de Nice quanto no caso de Seu Campos, constata-se que o emprego das relações pessoais para mediar a resolução dos problemas encontra amparo em uma realidade social em que éticas diferenciadas são legitimadas em virtude da complementaridade dos benefícios de um duplo pertencimento: de um lado, o caráter universal do cidadão, que iguala um homem a todos os outros homens; do outro, a 
natureza particular da pessoa, que discrimina favoravelmente um homem em relação aos outros homens. Nesse contexto, a participação, na escola, da mãe, da avó e da aluna Nice e do pai Seu Campos é condicionada pela inscrição de suas práticas nessa ética dúplice, o que possibilita, tanto a Seu Campos quanto a Nice, transitar do interesse particular para o interesse coletivo e vice-versa.

\subsection{A participação nas ações coletivas ${ }^{32}$}

Vários são os problemas que afligem o bairro onde está localizada a escola Altino Malafaia apontados pelos pais e mães entrevistados: a falta de uma área de lazer, necessidade sentida por mães cujos filhos são, ainda, pequenos, como é o caso de Cida e Ivete; a condição das ruas, não-asfaltadas em sua grande maioria, o que dificulta, em dias de chuva, o trânsito de pedestres - reclamação de Bete e Rosa, que, além disso, enquanto donas-de-casa, sofrem com o acúmulo de poeira em dias de sol; a inexistência de passarelas ou de passagens subterrâneas na rodovia federal, a colocar em risco a vida dos moradores pela insegurança da travessia - problema mencionado por Cida, Ivete, Zefa, Bete e Neusa; a falta de regularidade e eficiência no funcionamento do Posto de Saúde, que não dispõe nem de médicos em número suficiente, nem de remédios, nem de ambulância para transporte de doentes mais graves - privação experimentada, direta ou indiretamente, pelos vizinhos Nice, Chico, Elisa, Cida, Ivone, Ivete e Marta; a ausência de um sistema de esgoto sanitário, a ameaçar a saúde dos moradores, tal como o relataram Seu Campos, Chico, Rosa, Rute, Bete, Ivone e Ivete; a precariedade no

\footnotetext{
${ }^{32}$ Embora se tenha tratado neste item de práticas que ocorrem no cotidiano escolar e que podem concorrer para a constituição de um sistema de relações que vincule os atores, configurando um sujeito coletivo, incluo aqui a participação dos pais e mães nas ações coletivas porque, ainda quando estas ganham a cena pública, as diferentes orientações da ação e os seus diversos campos de referência se fazem presentes tensionando, e, às vezes, até rompendo, a frágil unidade do fenômeno, como veremos a seguir.
} 
fornecimento de água; a irregularidade na coleta do lixo...

Tantas são as dificuldades vividas pelos moradores que uma das mães entrevistadas, Zefa, ao ser indagada sobre o que faltava no bairro, assim resumiu a situação: "[Falta] alguém que zele por aqui, porque não tem."

Sujeito às mesmas agruras, Chico também percebe a amplitude do arco das necessidades mas, com previdência, indica uma instância que poderia encaminhar a resolução dos problemas experimentados pelos vizinhos - a associação de moradores:

"Uma das coisas que muito falta aqui dentro, até pra cobrar das autoridades, seria uma associação de moradores, tá? Porque, hoje, a associação de moradores, ela coordena o trabalho do bairro. Agora, um bairro onde você não tem um socorro ... [...] O posto fechou cinco horas, uma pessoa passa mal, o que a gente faz se não tiver um carro de uma pessoa pra ajudar? Então você fica à espera de um vizinho que queira socorrer. [...] Então o bairro hoje precisa, primeira coisa, é uma associação de moradores pra cobrar da pessoa que ganhar a eleição dentro do bairro [o vereador] as coisas corretas para o bairro."

Um dos motivos pelos quais a associação de moradores não se consolida como organização de vizinhos na defesa do espaço de moradia decorre do uso que dela fazem certas pessoas que, tencionando galgar posições mais elevadas na vida pública do município, fazem da associação mero trampolim, como relata Seu Campos, por pouco tempo vice-presidente de uma associação de moradores do bairro:

"A associação, o presidente era um camarada que ... ambicioso, mas com pouca instrução, muito ... analfabeto de pai e mãe, como chamam na gíria! E ele queria ser presidente de qualquer maneira, ainda houve briga na hora da eleição! Tinha um advogado aí, que foi candidato também: 'Não, quem tem que ser presidente é o Campos, porque não sei o quê.' Ele: 'Você está atropelando a minha reunião.' Ele queria ser, de qualquer maneira, presidente. [...] Ele aí se candidatou a vereador, que a ambição dele era essa, como presidente da associação de moradores se projetar e vir como vereador. Ele veio como candidato a vereador, e eu pedi demissão do cargo [de vice-presidente], e saí fora, não mexi com mais nada." 
Outro motivo pelo qual a associação não se materializa advém da própria falta de empenho dos moradores para quem a associação não se faz necessária, como conta Zefa:

"Então a gente estava pensando em fazer uma associação de moradores. Pra quê? Pra calçar a rua. Essa rua é horrível. Ou até pra gente pedir na Prefeitura que a gente fizesse uma cancela pra uma pessoa ali ... diário ... pra não estar entrando qualquer pessoa, não ter perigo por causa das nossas crianças. Mas não tem é ... não tem ... como é que eu vou te falar? Não tem ... o pessoal não ajuda, dois, três quer, o resto ninguém quer. Acha que não tem necessidade."

Mais grave é a desmobilização dos vizinhos em conseqüência da atuação de certos vereadores que, atendendo às solicitações de maneira particular, neutralizam os possíveis encaminhamentos coletivos, conforme denuncia Ivete:

"Não, porque ... aqui é assim: se ... se ... se dez dá uma opinião, quer correr atrás, aí sempre tem um que vem com um pé atrás: 'Ah, não ... não vamo querer levar presse lado, que não sei o quê.' E sempre tem um vereador comprando alguém pra alguma coisa. Então fica difícil como eu falei. Pôxa, a gente tem que correr atrás de uma associação. O bairro precisa de uma associação. Porque uma associação é uma coisa quê? Uma associação leva a um saneamento básico, vai levar a uma área de lazer, vai levar ao melhor ... um posto policial. Dentro de uma associação a gente pode correr atrás disso tudo. Mas ... eles se enfraquecem, eles se deixam levar por pouca coisa ..."

Se a melhoria do bairro não tem a força de uma aspiração que congregue os vizinhos em torno de uma associação de moradores, nem mesmo os problemas pontuais (o não asfaltamento das ruas, a ausência de um sistema de esgoto sanitário, o funcionamento irregular e precário do posto de saúde, etc.) são suficientes para provocar algum tipo de mobilização coletiva. Indagados sobre as razões pelas quais os moradores não se uniam para reivindicar em conjunto determinada melhoria para o bairro, os pais e mães entrevistados apontavam a acomodação e o medo como os óbices mais importantes à participação, justificando sua avaliação em suas próprias experiências com os parentes ou com os vizinhos. 
Assim, Cida julga que parte das pessoas não se mobiliza por falta de vontade de colaborar, a exemplo de sua irmã:

"Eu acho que isso aí ... no meio de cem, têm sempre uns dez que já é mais preguiçoso mesmo. Vamos botar dessa maneira. Tem muita gente que não gosta de fazer nada, de participar de nada. Essa minha irmã mesmo, essa que saiu daqui agora é uma. Quer dizer, eu já estou aqui pra tudo. Se bater alguém ali agora e me chamar: 'Cida, estão chamando você ali agora pra você ajudar.' Tô indo. Agora, se chamarem ela: 'Ah, eu não, eu não vou não.' É assim. [...] Quer dizer, tem muita pessoa, têm muitas pessoas que são acomodadas demais."

De modo análogo Rosa julga que é a acomodação dos vizinhos que faz com que a sua saúde e a dos próprios vizinhos esteja permanentemente em risco, pois quando ocorrem chuvas contínuas a água pluvial misturada com os dejetos das moradias, sem ter por onde escoar, entra nas casas; e que, afinal, é a acomodação dos vizinhos que determina a omissão do poder público:

"Eu acho que o pessoal se acomoda muito. Vê as valas, estão tudo entupido, tudo cheio de mato. Quando chove, dá enchente e entope tudo, fica aquela danação, entrando água em várias casas aí. [...] Quer dizer ... mas não adianta uma ou duas pessoas falarem, tinha que se juntar todo mundo e reclamar, não adianta uma nem duas, três pessoas falar. Quer dizer ... o pessoal se acomoda. Aí o Prefeito fica nessa, ele manda não é nem limpar, ele manda roçar de tempos em tempos."

Como conseqüência da omissão do poder público, aos moradores só resta a alternativa da solução própria, individual, dos problemas, em uma atitude de inércia que é similar à da administração municipal. Ao ser perguntada sobre a reação da população diante de um problema como o mencionado por ela, Rosa assim respondeu:

"Eu acho que deixa rolar. Cada um resolve sua parte, um limpa seu pedaço, outro faz uma coisa, e deixa assim mesmo."

A acomodação também pode ser percebida em moradores que, cansados de sofrer com a abstenção do poder público municipal, tentam tirar proveito em época de eleição e procuram barganhar o voto, por exemplo, com manilhas doadas pelo Prefeito ou pelo 
candidato da situação à Prefeitura. Este procedimento é, muitas vezes, antecipado pelo próprio Prefeito ou pelo seu candidato, de acordo com a denúncia de Chico:

"As pessoas já estão cansadas de ficar brigando e só ver levar na barriga: 'Ah, a gente vai resolver.' 'A Prefeitura não tem dinheiro.' As pessoas já se acostumaram, a Prefeitura já tomou conta delas. E já vem de governo e mais governo, e os prefeitos não se preocupam em saneamento básico do município. [...] As pessoas vão em cima, quando chega perto da eleição ela ... ela recebe muita promessa, né, e uma dessas promessas ... geralmente o prefeito que está com a máquina na mão ou o [candidato a] prefeito indicado pelo cara que está com a máquina na mão, eles arrumam umas manilhas até pra chegar nessas pessoas. Às vezes, nem as pessoas chegam nele, muitas das vezes eles chegam nas pessoas e fazem uma proposta."

O medo também imobiliza os moradores, levando-os a eleger aqueles dentre eles que se mostrem mais ousados, com mais iniciativa, conforme a avaliação de Cida:

"Eles sempre procuram um que faz alguma coisa, que vá por eles, tipo um escudo. Quando não é eu, é o Chico. Eles botam aquele escudo: 'Não. Você vai comigo!' Eu acho que eles têm medo de alguma coisa, não sei o que é, mas têm medo."

É o medo, ainda, que faz com que os vizinhos marquem a diferença entre eles e "os líderes", visto que consideram as iniciativas de Cida algo inusitado, que alguém, em sã consciência, não teria, segundo ela mesma conta:

“O povo é medroso, tem medo, tem medo. Eles já falaram comigo: 'Você é doida de fazer o que você faz.'

Do ponto de vista de Cida, no entanto, não é assim que a situação é percebida. Esta moradora, ao se conscientizar de que a intervenção é necessária em face das carências vividas por sua família, inverte a lógica expressa pela população, e aposta na capacidade de mudança que a união de vontades traz:

"Eu disse: 'Doida não, doida é deixar de fazer alguma coisa, porque está aqui a minha filha, tem a minha família. [...] A verdade é essa: o povo não sabe a força que tem. Se ele soubesse, isso aqui não estava assim do jeito que está." 
O medo também é mencionado como decorrência de um comprometimento originário das práticas de corrupção, pois se um morador - nos termos de Seu Campos - vende o seu voto para Beltrano por trinta reais, ele se encontra impossibilitado de pressioná-lo para realizar melhorias em seu bairro, uma vez que a recompensa pecuniária foi associada a interesses particulares (de Beltrano), deslegitimando aqueles que seriam os interesses comuns (da coletividade). É o que nos relata Zefa:

"Mas é muito ... é medo, o pessoal lá se envolveu muito com o vereador deles lá, então eles botam a viola dentro do saco e ficam quieto." [...] "Tanto que a gente pediu uma ajuda, eu não, mas teve gente que foi pedir uma ajuda para o prefeito, para o prefeito não, para esse vereador, e ele falou que ele não ia ajudar porque todos os votos dele, lá do outro lado, é comprado."

Em que pesem as carências serem múltiplas e variadas, e não se consiga mobilizar os moradores em torno da superação dessas carências junto ao poder público - seja pela via da associação de moradores, seja pela via da arregimentação momentânea em torno de problemas pontuais - , e em que pese, ainda, a falta de vontade de colaborar de alguns, as dificuldades dos moradores não são menosprezadas por seus vizinhos, que a elas acodem sempre que é possível. Nesse sentido, as relações solidárias intervêm para tentar suprir as carências experimentadas de modo individualizado. É o que acontece, por exemplo, quando alguém necessita de um pronto atendimento médico e precisa ser levado a um hospital; a família ou os vizinhos procuram sempre aqueles que tenham meio de transporte próprio para o socorro imediato, como nos contam Cida e Chico:

"Um senhor aí, está com a pressão alta, não tem como. O meu carro parece até ambulância. É dia e noite, madrugada ... As mulheres todinhas aqui para terem neném, a única que leva no hospital sou eu. Todo mundo bate aqui. [...] Eu até falei que ia botar uma sirene em cima desse carro aí." (Cida)

"Nós tivemos até um caso de ... da esposa do seu Alvino, que veio a falecer, ficaram quarenta minutos com enfarte galopante - procurando carro e, infelizmente, não tinha um carro. Eu não estava em casa, estava numa reunião; infelizmente eu não estava. Porque se eu estivesse em casa, a gente poderia pedir ali, pegar ela no colo, levar até no 
ponto do ônibus, botar numa Kombi, botar num carro que fosse passando, parar. Então nós tivemos esse fato." (Chico)

Desse modo, em face de necessidades prementes, é o estreitamento dos laços diretos entre as pessoas que contribui para a criação dos vínculos de solidariedade, e que garante o apoio mútuo em momentos de precisão.

No bairro em questão, foram essas relações - caracterizadas pela fraternidade e pela compaixão - que deram origem às poucas mobilizações em que se envolveram os moradores. Dois foram os móveis das mobilizações coletivas: os atropelamentos seguidos de morte na rodovia federal - que acarretaram pelo menos duas paralisações na rodovia $^{33}$ - e a destituição de Neide do cargo de diretora da escola, após quinze anos à frente da unidade - que motivou uma caravana à Prefeitura. Assim, foi a solidariedade com os pais e parentes das pessoas mortas e com a diretora Neide que condicionou tanto as paralisações quanto a caravana.

No caso dos atropelamentos, as paralisações aconteceram em intervalo de tempo muito curto, à medida que se iam intensificando as ocorrências; a mais recente, de abril de 2000, chegou a ser veiculada no noticiário local da Rede Globo de Televisão, por influência de uma vereadora do Rio, conhecida da madrinha do menino morto.

Todo esse processo, segundo o relato de alguns entrevistados, se, por um lado, significou uma importante conquista dos moradores, por outro, não deixou de ser marcado por tumulto e desentendimentos entre os próprios moradores, e entre os moradores e a diretora da escola. Assim, por ocasião da primeira paralisação, as

\footnotetext{
${ }^{33}$ Não pude precisar quantas paralisações foram feitas na rodovia federal em razão dos atropelamentos, variando entre duas e quatro paralisações, de acordo com o entrevistado.
} 
divergentes orientações da ação dos manifestantes, acarretando a não obediência ao que havia sido acordado com a Polícia Rodoviária - um período determinado de interrupção no tráfego de veículos para que não houvesse caos no trânsito - contribuíram para que a manifestação terminasse em tiros e correria. Já por ocasião da paralisação mais recente, um desentendimento entre a mãe de um aluno morto na rodovia, que liderava vizinhos, e a diretora aconteceu, porque esta tinha os interesses da escola como campo de referência de sua ação, enquanto aquela tinha como campo de referência os laços familiares. Por essa divergência, Neide contrariava Leoni - a mãe do aluno morto - que queria uma reunião com o Prefeito nas dependências da escola, enquanto a diretora, argumentando que o aluno não havia sido atropelado em horário de entrada ou saída da escola, questionava os moradores por terem marcado essa reunião na unidade escolar.

Também nessa reunião - que acabou ocorrendo na escola - os interesses a serem defendidos, a saber, providências que pudessem dar fim aos atropelamentos, não conseguiram sustentar a conformidade nas orientações da ação dos moradores, tornando possível à administração municipal propor uma solução que pôs os vizinhos em discórdia. É assim que essa reunião dá-nos a oportunidade de observar a determinação de uma mãe, Zefa, que, solidária com o sofrimento de sua vizinha Leoni, mostra saber que providências seriam, de fato, efetivas, recusando-se a aceitar a pretensa solução apresentada pelo poder público municipal:

“Ele [o Prefeito] chegou, olhou os cartazes e falou: 'É minha gente, eu não tenho nem o que falar pra vocês.' [...] Tem uma mãe, que até mora do lado de cá, que eles pediram a ela pra fazer o ... como é o nome do negócio? Ia ter um negócio ali na escola que ia ser tipo uma educação pra criança, uma educação de trânsito pra criança. Não tem nada a ver ... eu, que sou adulta, pra atravessar ali é um sacrifício! Não tem educação de trânsito pra criança ... isso não existe! Aí começaram lá ... ao invés de estar conversando sobre o nosso problema, começaram a conversar sobre esse negócio de educação no trânsito. Eu me explodi com eles, eu falei com eles: 'Ó, vocês vieram aqui pra resolver o quê? O nosso problema: uma passarela, um túnel subterrâneo, alguma coisa que vá nos auxiliar na travessia da pista? Não veio aqui pra falar negócio de educação de 
trânsito.' A criança não entende, não adianta, por mais que entenda, teve carro que tomou criança da mão do pai, ali do outro lado da pista, vindo da escola. Então não adianta isso. Aí, eu sei que teve gente ... é até minha colega de infância ... hoje, ela fala comigo, mas na época ela ficou chateada comigo por causa disso. Porque, quando o filho da Leoni foi atropelado, eu fiquei até doente por causa dele. [...] Eu fiquei com ele aqui, na sexta-feira, até tarde. Teve o aniversário do meu filho na sexta, eu fiz o do meu filho na sexta pra mãe dele fazer o do irmão dele no sábado. Então, quer dizer, ele ficou aqui, com a gente, até tarde brincando. Depois que acabou o aniversário, a gente jogou as coisas avulsas, uma farra danada, pra no sábado você ver a criança daquele jeito ali! Você se revolta! Então eu me revoltei. Eu achei que tudo que você falasse que não fosse interesse nosso, daquilo ali que a gente estava vivendo, era coisa banal, não precisava nem ser falado. Não tinha nada a ver aquele negócio de educação de trânsito, era pra distrair as pessoas. E tem muitas pessoas que se distraem, entendeu? Então o pessoal ficou meio bronqueado comigo por causa disso, e porque eu disse que ia botar uma faixa no portão da escola e ninguém ia entrar."

Como complemento da determinação de Zefa, também sua clareza política a auxilia a perceber as artimanhas da administração municipal destinadas a arrefecer o ânimo dos manifestantes. Assim, as expectativas criadas pela assessoria do Prefeito em torno de sua presença na reunião acima mencionada tinham por objetivo reduzir o nível das exigências pela satisfação dos moradores com a tão esperada chegada do chefe do executivo - manobra bem percebida por Zefa:

“Aí pediram uma reunião com o Prefeito. Aí ficou aquela burocracia toda ... que ele estava indo viajar, mas que estava voltando ... Pra iludir também um pouco o pessoal: 'Ah, o prefeito está viajando, mas vai voltar do meio do caminho por causa de vocês.' Botou na pressão pra ver se a gente não fazia mais nada. Ficamos lá sentados, horas, esperando, e ele chegou."

No embate com os poderes constituídos, a persistência, tanto individual quanto coletiva, é considerada por Zefa e por Cida um instrumento de luta para que se obtenham vantagens cada vez maiores:

"Agora, dia desse, ali, acho que foi na segunda-feira, segunda ou terça, morreu o Seu Geraldo, na pista também, um senhor de idade, acho que tinha setenta anos. Foi no Zé comprar uma coisinha pra ele, na travessia ali, ele morreu. Quer dizer, eles ficam quietos. Se juntasse todo mundo e fizesse outro protesto ali, já resolveria alguma coisa, já ia conseguir mais alguma coisa. No primeiro não conseguiu o redutor [de velocidade]? Faz mais um e consegue mais alguma coisa." (Cida) 
"Eu gastei um bom dinheiro com telefone. Todo dia eu perturbava eles [os guardas rodoviários]. Tinha dia que acordava mais cedo, arrumava as crianças, e ligava aqui de casa: 'Eu queria saber se tem a viatura aqui pra atravessar as crianças da Altino Malafaia.' 'Ah, ainda não foi não, estava fazendo ... (sei lá como eles falam) ... estava fazendo uma ocorrência.' Eu falei: 'Ah, mas não tem outra viatura não? Não vou deixar as crianças estudarem.' 'Ah, mas quem é a senhora?' Eu desligava o telefone, não falava quem era eu. Então, por causa de tanta pressão, eles, hoje em dia, em todos os horários eles estão ali." (Zefa)

Embora as providências esperadas pelos moradores - seja uma passarela, seja uma passagem subterrânea - não sejam exequiíveis, segundo informações de entrevistados que consultaram os organismos responsáveis pela rodovia federal, algumas conquistas decorreram das paralisações, tais como: a colocação de redutores de velocidade, de placas de sinalização, e de faixas de segurança; e a presença de um guarda rodoviário no horário de entrada e saída da escola - embora essa presença não seja regular, a depender das ocorrências que a Polícia Rodoviária tenha de atender.

No que se refere à destituição de Neide do cargo de diretora - após quinze anos à frente da escola e após convivência com administrações municipais de variadas tendências políticas $^{34}$ - seu afastamento sensibilizou, com maior ou menor intensidade, pais e mães de alunos. Cida, Chico, Nice, Ivete, Ivone, Rosa e Seu Campos manifestaram com grande ênfase seu apoio à pessoa de Neide e à forma como esta vinha dirigindo a escola:

"E ali, eu acho que a escola estava bem administrada pela Neide, uma diretora excelente, todo mundo gosta demais dela, você não vê ninguém falar dela, eu estou aqui há dois, três anos ... gente, eu que vim praqui agora, era pra mim começar a ver algo diferente, né?" (Ivone)

"Pelo que eu vejo ali, a Neide é mãe, bem dizer, mãe dos filhos da gente. Ela trata de todo mundo muito bem, ela participa a todo mundo o que está acontecendo com um aluno. Se um aluno se machuca ali, ela corre, socorre a criança, leva pro hospital, manda chamar os pais em casa. Quer dizer, ela ali não esconde nada de ninguém,

\footnotetext{
${ }^{34}$ Tudo indica que Neide foi exonerada por ter, no desempenho de suas funções de diretora, apoiado publicamente seu cunhado, candidato a Prefeito no município na última eleição. Ao ser questionado pela sobrinha de Neide sobre o motivo da exoneração, o Prefeito reeleito limitou-se apenas a afirmar que direção de escola era cargo de confiança do chefe do executivo, não declarando expressamente ter acontecido tal fato.
} 
procura sempre fazer o melhor. Eu nunca vi ninguém reclamar dela também não. [...] Ainda têm umas meninas, né, uns rapazes que já estudaram ali, ali em baixo também, e continuam freqüientando o colégio até hoje só pra cumprimentar a Neide. Só pra ir lá e saber como que ela está. Quer dizer, ela fez uma boa administração na escola. Se ela tivesse sido ruim ou tivesse feito alguma coisa de errado, ninguém ia procurar ela, só pra ver, desejar um feliz Natal: 'Oi, como está?’ Ninguém faria isso.” (Cida)

Mas se aqueles pais e mães aprovavam a gestão de Neide na unidade escolar, outros a ela se referiam com menor entusiasmo, com reservas, ou mesmo com descompromisso:

"Olha, por isso [pelo fato de Neide, no cargo, ter publicamente apoiado o cunhado na eleição para prefeito], eu até acho que não deveriam ter tirado ela não. [...] A Neide, tem muitos anos já que ela é diretora. Eu estudei na escolinha lá em cima e a Neide era professora, né, quando eu era criança. Então, ela é uma pessoa boa, uma diretora boa, mas só que ela já não tinha pulso forte ali com ninguém mais. [...] E as crianças daqui, têm muitas crianças boas, mas têm muitas crianças que são da pá virada. Então, precisava de uma pessoa de pulso forte ali dentro." (Zefa)

"As pessoas acham que ela não deveria sair, deveria continuar. Porque, no caso, a Vera [professora de Religião, cotada para substituir Neide], ela não tem competência para assumir uma diretoria de uma escola. É o que as pessoas falam, né. Eu conheço ela há pouco tempo, entendeu?" (Bete, que mora há quatro anos no bairro)

Até mesmo Elisa, que chegou a participar da caravana à Prefeitura, expressou seu desagrado em relação à Neide, em decorrência de sua omissão como diretora (ver subitem 2.3.4): "Pra mim ela não é muito boa não. Pra mim." Mas, tendo em conta a possível posse de Vera no cargo, essa mãe acaba por redimensionar sua insatisfação, e considerar ser preferível a permanência de Neide do que a sua substituição por Vera assinalando uma orientação da ação diversa daquela movida por pura solidariedade à diretora:

"Porque pra botar outra pessoa no lugar dela que não tivesse competência é melhor que deixasse ela. Porque ela está aí desde o começo, há muitos anos que ela está no colégio. Tirar a mulher de uma hora pra outra, e botar uma pessoa que não tem nada a ver, que nem estudo tem pra dirigir a escola ... Aí foi onde que reunimos e fomos lá pra fora." 
Embora nem todos os pais e mães entrevistados tivessem se dirigido em caravana à sede do governo municipal por variados motivos - trabalho, viagem, e até mesmo por não querer se envolver - todos tomaram conhecimento da exoneração de Neide e de uma reunião na escola para discutir o assunto seja através de vizinhos, por comunicação pessoal da própria Neide, e até mesmo por meio de um carro com alto-falante que circulou pelas ruas do bairro.

Essa reunião, organizada por Chico e por Cida, foi motivada por um contato telefônico com o Prefeito, que, ao confirmar a exoneração de Neide, provocou sua convocação pelos pais e mães de alunos. Nas palavras de Chico:

\begin{abstract}
"Nós ligamos pro Prefeito, eram sete horas da manhã, e aí tínhamos doze pais de alunos, tá, que queriam conversar com ele. [...] A resposta que o Prefeito mandou pra gente era a seguinte: 'Ela está exonerada, e ela não vai trabalhar na escola mais. A Neide só fica na escola como professora, se quiser.' [...] Eu falei: 'Eu acho que tem alguma coisa errada.' Aí nós fizemos uma ... juntamos um grupo [...], aí mandamos um recado pro Prefeito, marcando com ele que nós estaríamos no dia seguinte aguardando ele, às nove horas da manhã."
\end{abstract}

A essa reunião acorreram pais e mães de alunos em fluxo variável, na medida que as ocupações domésticas e as obrigações de trabalho permitiam. Houve momentos de maior presença na expectativa da chegada iminente do Prefeito, e um momento em que, afinal, os presentes se deram conta de que o Prefeito não viria mais. De acordo com Chico, durante as três horas em que os pais e as mães ficaram esperando pelo Prefeito, este postergou o mais que pôde o tão esperado encontro, até que, diante da ameaça do deslocamento dos pais ao prédio da Prefeitura, sua secretária apelou a ele, Chico, para que os mantivesse na escola:

"Nós esperamos às nove, nove e meia, aguardamos meia hora de tolerância, aguardamos até as dez: uma hora. Nós ligamos pro Prefeito. A secretária falou que o Prefeito estava em reunião, e que não ia poder ir, mas ia arrumar uma pessoa; pra gente aguardar um pouquinho que já estava chegando. Esperamos até onze horas, aí não 
apareceu. Eu liguei pra ela pra dizer pra ela que as pessoas estavam já nervosas e queriam ir direto lá pra Itaguaí. Ela virou pra mim ... a secretária falou: 'Eu não sei se vai dar pra ele ir.' Eu falei: 'Eu vou aguardar mais meia hora, e se as pessoas quiserem ira lá pra fora elas vão lá pra fora. As pessoas vão a pé porque elas não têm dinheiro.' Ela falou: 'Segura eles aí o que puder aí."

Houve, então, a proposta de que Chico e Cida fossem à Prefeitura representando os pais de alunos, proposta alterada pela vontade manifesta de muitos pais e mães de se dirigirem para lá também:

"Ele [o Prefeito] deixou a gente três horas esperando e não compareceu. Aí o pessoal falou assim: 'Então vai o Chico e a Cida representando a comunidade.' 'Vamos.' Eu perguntei: 'Vocês querem ir lá pra fora?' 'Queremos.' 'Então vamos.' (Cida)

Ainda que alguns deles estivessem dispostos a ir a pé até à Prefeitura, decidiu-se arrecadar dinheiro para custear o transporte de todos:

“Os pais falaram assim: 'A gente vai a pé.' Aí no caso, [...] nem todos queriam ir porque não tinham o dinheiro da passagem. E aí nós fizemos um rateio entre a gente e conseguimos duzentos e cinqüenta reais. Quem tinha dinheiro foi dando, os pais de alunos foram dando, e mais dois empresários, que até passaram na hora - duas pessoas de material de construção -, que deram uma forcinha pra gente: 'Eu pago aí seis kombis pra vocês irem.' (Chico)

Ao chegarem ao prédio da Prefeitura não foram recebidos de imediato pelo Prefeito, que lançou mão da tática habitual das autoridades públicas em situações de pressão popular: tentar diminuir a intensidade dos ânimos pela imposição da espera prolongada. Diante da insistência dos manifestantes - que, a essa altura, incluíam não apenas pais e mães de alunos, mas, ainda, os próprios alunos, funcionários, professores e parentes de Neide, a diretora exonerada - foi-lhes comunicado que o Prefeito não viria conversar com eles, mas que receberia uma comissão de representantes, formada por três pais e por dois professores. 
Desse encontro, marcado pelo constrangimento da comissão - que teve de dialogar não somente com o Prefeito mas também com sua numerosa assessoria - e pelo apelo emocional deste - que a ele próprio se referia pelo apelido ‘nêgo véio' - , nada resultou: Neide não foi reconduzida ao cargo.

Mas se esse encontro ensejou que se desse desdobramento ao movimento dos pais e mães em prol da permanência de Neide no cargo - através de manifestações favoráveis de pais e mães na rádio Grande Rio - também esse encontro dá-nos a oportunidade de registrar uma vez mais que nem sempre os interesses a serem defendidos são suficientes para sustentar a conformidade nas orientações da ação, abrindo a guarda para uma possível divisão no movimento. Assim, foram as divergências entre os pais representantes que determinaram o encerramento prematuro da reunião com o Prefeito, conforme nos conta Cida:

"Aí foi eu, Chico, dois professores, e foi mais uma senhora, uma mãe de aluno também. Essa mãe de aluno só abriu a boca pra falar assim: 'O prefeito não quer, gente, vamos embora.' Eu falei: 'Não! O nosso objetivo foi vir aqui e tentar convencer ele. Então vamos lutar pra isso até o finzinho. Eu tenho certeza que ele vai dar uma resposta melhor pra gente.' Ela poderia ter falado alguma coisa, ela poderia ter ajudado. Se ela foi pra ficar lá em cima, ficar quieta, escutar a última palavrinha e dizer: 'Não, vamos embora, o prefeito não quer, não quer.' Não é assim. Poderia ter subido outra pessoa que pudesse ter falado mais alguma coisa. Já era mais uma força. Quer dizer, no meio de cem, têm sempre uns dez que se acomodam. Quer dizer, se ele fala pra mim: 'Não quero, não quero' E acabou? Se fosse assim, todo mundo que tinha vindo pra cá tinha ficado quieto. Não! Fomos todo mundo do mesmo jeito: 'Vamos ... a coisa que a gente tem pra conversar com o povo não é a rádio? Vamos ligar pra Grande Rio e vamos conversar com eles e vamos ver o que que eles falam."

Embora a pressão popular se fizesse ainda presente por algum tempo, através de solicitações isoladas ao chefe do executivo, de oposição velada à Vera que - se imaginava - ocuparia o cargo de diretora, e de pronunciamentos descontentes de pais e mães de alunos na emissora de rádio local, a decisão tomada pelo Prefeito de substituir Neide por seu marido, também servidor do município, e de convidá-la para assumir 
cargo técnico-administrativo graduado na Secretaria de Educação contribuiu para o abrandamento dos ânimos e para a desmobilização da população. 


\section{Conclusão}

\section{Particípação coletiva e particípação fragmentada: formas de particípação que não se contrapõem}

Acompanhando a trajetória das camadas populares no cenário público nacional observase, na década passada, uma relativa ausência de participação destas, que se seguiu a dois períodos bem definidos em que as camadas populares se mostraram politicamente importantes.

Enquanto, no primeiro período (de 1930 a meados dos anos 60), sua emergência na cena pública se deu atrelada a um Estado que, para legitimar-se, incorporou-as ao processo político na condição de um novo ator a quem teve de reconhecer as reivindicações, no segundo período (nos anos 70 e 80), as camadas populares desafiaram o Estado, que havia imposto uma "despolitização" e uma disciplinarização da vida social, ao trazerem para a vida coletiva as experiências individuais da vida privada, originárias das carências urbanas.

No entanto, após essa marcante presença das camadas populares na cena pública sucedeu-se sua relativa obscuridade, condicionada que foi, na dimensão interna, pela redemocratização da sociedade brasileira, e, na dimensão externa, por um novo modelo de desenvolvimento instituído por uma nova ordem internacional representada pela globalização.

Assim, em face da possível crise que incide sobre as mobilizações coletivas, e que não poupa o campo da educação, poder-se-ia perguntar se não se estaria observando um 
período de desestruturação dos movimentos, que acarretaria a ausência de participação das camadas populares.

Se considerarmos o despontar dessas camadas, tal como se deu nos períodos anteriormente mencionados, poder-se-ia concluir que, de fato, a não-visibilidade social das manifestações populares na década de 90 expressa a ausência de participação daquelas camadas.

Contrapondo-se a esta perspectiva, este trabalho procura investigar formas de ação e configuração dos sujeitos que permitem reafirmar a presença das camadas populares, observando a participação de pais e mães de alunos em uma escola pública de ensino fundamental situada em bairro popular do município de Itaguaí no estado do Rio de Janeiro.

O que se registra, então, é uma diversidade de práticas de participação que mostram o envolvimento de pais e mães na vida cotidiana da escola de seus filhos, ainda que aqueles mesmos pais e mães compartilhem de uma representação social que os fazem associar a participação estritamente à presença em reuniões ou à contribuição em dinheiro para as festas escolares.

Desse modo, o envolvimento de pais e mães na escola dos filhos inclui não apenas aspectos referentes à educação destes últimos, mas, ainda, aspectos referentes à própria identidade feminina das mães na medida que a escola constitui um âmbito em que estas e as educadoras disputam o poder sobre as crianças. Além disso, a questão da identidade feminina também favorece a participação, na medida que o trabalho doméstico 
executado pela mulher no âmbito privado pode ser revertido em benefício do aluno ou da escola, projetando a mulher no espaço público.

O envolvimento de mães é condicionado, ainda, por suas histórias pessoais de vida que acabam por valorizar sobremaneira a escola como um bem de que se pode usufruir no presente, em que pesem as dificuldades experimentadas no passado.

Em uma sociedade como a brasileira, marcada por uma ética dúplice, a participação de pais e de mães também se orienta por esse caráter diferenciado de uma norma de conduta que preserva na escola tanto os interesses particulares - fazendo uso da relação - , quanto os interesses coletivos - fazendo uso da condição de cidadão.

Ainda que as práticas observadas não esgotem todas as formas em que pais e mães podem participar da escola de seus filhos, e que tenham por referência o lugar onde elas ocorrem - uma escola pública de ensino fundamental num bairro popular do município de Itaguaí - , essas limitações não impedem que se registrem formas de ação e configuração dos sujeitos que fogem ao padrão de participação encontrado nos movimentos sociais, e que, nessa condição, caracterizam uma participação que denominei fragmentada.

No contexto dos movimentos sociais, a ocupação dos espaços públicos, o confronto com as autoridades, os abaixo-assinados, as caravanas, os atos públicos, e a criação de canais institucionais - como as Associações de Pais e Mestres e os Conselhos de Escola davam às ações o caráter de visibilidade social. 
No âmbito da escola pública estudada, no entanto, as ações não têm a característica de serem socialmente visíveis porque se referem a aspectos bastante singulares da experiência de pais e de mães na escola de seus filhos. De toda forma, embora pais e mães não façam parte de um sujeito coletivo, não deixam de se constituírem sujeitos porque não deixam de produzir um significado para aquilo que fazem.

Essas noções de sujeito e de significado são extremamente importantes porque, em primeiro lugar, permitem compreender que identidade individual e identidade coletiva não são entidades absolutamente estranhas uma à outra, e, em última instância, compreender, ainda, que a participação (sob a forma) fragmentada pode levar à participação coletiva. Para isso Alberto Melucci dá relevante contribuição.

Ao levar em conta os resultados de pesquisas de natureza psicológica e sociológica que mostram que o desenvolvimento da identidade individual acontece em uma relação circular com um sistema de delimitação - Melucci concebe a identidade como um campo de relações que, ao mesmo tempo que fundamenta a identização (o processo de construção auto-reflexivo da definição de nós mesmos), fundamenta a individuação (o processo de construção de nossa consistência no interior dos limites colocados pelo ambiente e pelas relações sociais).

Desse modo, constituímo-nos enquanto indivíduos na medida que somos sujeitos autônomos da ação e de criação de sentido para as coisas mas no exato entrocamento dos aspectos propriamente individuais com os aspectos propriamente relacionais e sociais da identidade: 
"É, portanto, impossível separar de modo rígido os aspectos individuais e os aspectos relacionais e sociais da identidade. Na história individual a identidade se apresenta como um processo de aprendizado que leva à autonomia de um sujeito. Através de diversas etapas adquirimos uma capacidade de resolver os problemas colocados pelo ambiente e uma independência nas relações. A interiorização do universo simbólico da cultura e a capacidade de interpretar culturalmente as necessidades substituem a dependência 'natural' do ambiente: primeiramente como integração naquele universo simbólico, depois como processo de individuação, o que permite certa independência do sistema. Tornamo-nos capazes de produzir de modo autônomo aquilo que, antes, devíamos receber dos outros." (Melucci, 1992, p.37)

Portanto, Melucci chama a atenção para o fato de que a nossa identidade se apresenta como um processo, pressupondo um sujeito de ação que tem a capacidade de produzir e de reconhecer o significado daquilo que faz dentre as possibilidades e os limites colocados por um certo ambiente e em meio a um sistema de relações sociais, em uma dinâmica toda própria:

"a identidade é um processo de constante negociação entre partes diversas de si, tempos diversos de si e ambientes diversos ou sistemas diversos de relações em que cada um de nós está inserido". (Melucci, 1992, p.55)

Há, ainda, um aspecto a destacar nessa identidade referida a diversos fatores, que decorre da situação do sujeito no interior de um sistema de relações: é que a possibilidade de distinguir-se dos outros deve ser reconhecida por esses outros. Isto significa que a unidade pessoal (identidade), que é produzida e mantida pela autoidentificação, se apóia sobre o pertencimento a um grupo, e, mais ainda, depende do reconhecimento intersubjetivo, mas não coincide inteiramente com ele:

\begin{abstract}
"Se é verdade que a nossa identidade se funda somente em uma relação social, e para que seja identidade deve ser interação, reconhecimento recíproco entre nós e os outros, então a identidade contém uma tensão irresolvida e irresolvível entre a definição que damos de nós mesmos e o reconhecimento que os outros nos dão: a identidade comporta uma diferença entre a auto-identificação e a identificação que vem de fora." (Melucci, 1992, p.39)
\end{abstract}

Assim, se a identidade é um processo de contínua negociação (“entre partes diversas de si, tempos diversos de si, e ambientes diversos ou sistemas diversos de relações em que 
cada um de nós está inserido" e "entre a definição que damos de nós mesmos e o reconhecimento que os outros nos dão"), é justamente o significado que os atores produzem para aquilo que fazem que, paradoxalmente, lhes possibilita transcender a jurisdição estritamente individual de suas ações (identidade individual) para alcançar um âmbito em que as ações podem se articular tecendo vínculos entre os indivíduos (identidade coletiva). Ressaltando que "as razões para estar e permanecer juntos devem ser ou descobertas ou socialmente construídas" (Melucci, 1996, p.215), este autor complementa:

"Chamo de identidade coletiva uma definição interativa e compartilhada que muitos indivíduos produzem a respeito das orientações da ação e do campo de oportunidades e de vínculos no qual essa se coloca; interativa e compartilhada significa construída e negociada através de um processo repetido de ativação das relações que unem os atores." (Melucci, 1991, p.53)

Ao refletir especificamente sobre o tema da identidade coletiva, Melucci (1996; 1997b; 2000) destaca a importância que o significado produzido pelas pessoas na vida cotidiana têm para as dimensões políticas e sociais da vida coletiva. Para ele, não é uma condição comum dada por antecipação ou a mera convergência de interesses que garantem o agir coletivo; antes, é o significado que os atores produzem para aquilo que fazem que, concorrendo para uma identificação entre indivíduos ou grupos, permite a constituição dos vínculos entre eles:

"Não nos sentimos ligados aos outros pelo fato de termos interesses comuns, mas, antes, porque essa é a condição para reconhecer o sentido daquilo que fazemos. Graças à solidariedade que nos liga aos outros podemos afirmarmo-nos como sujeitos de nossa ação e podemos suportar a ruptura que o conflito introduz nas relações sociais." (Melucci, 1992, p.40)

"O sentido que os atores produzem não se constitui só no interior da política, mas a precede na experiência social de cada um. Sem fazer referência ao sentido, a política se torna procedimento, simples exercício de técnicas. Reduz-se assim à manipulação do consenso e otimização das decisões, sem alguma justificação que não seja instrumental. A justificação da política pode vir somente da capacidade de produzir sentido por parte daqueles que participam e definem o espaço da polis" (Melucci, 1997b, p.53-54) 
Nesse contexto, os significados que os pais e as mães aqui apresentados concedem para suas ações nas experiências singulares da vida cotidiana têm uma importância vital para a dimensão política e social da vida coletiva, restabelecendo a ligação entre a participação (sob a forma) fragmentada e a participação coletiva. Isto porque esses significados, embora trazendo a marca da particularidade, não se encontram determinados desde sempre, não se encontram "fechados", pois estão condicionados pela experiência desses 'pais e mães' enquanto sujeitos.

Por conseguinte, enquanto sujeitos, os pais e as mães de alunos estão destinados a passar pela experiência que representa a vida escolar dos filhos, reajustando continuamente os diferentes fatores que sobrevêm em um determinado momento e os adaptando a outros fatores oriundos da experiência passada.

Assim, se são justamente os tempos e os lugares que criam as circunstâncias para a vivência de experiências singulares - como as dos pais e das mães aqui relatadas - são, ainda, os tempos e os lugares que condicionam a escolha de valores e ideais comuns a agregarem coletivamente os indivíduos. Entre a vida cotidiana e os momentos de mobilização e de luta, entre as necessidades particulares e as necessidades coletivas, persiste como elo de ligação o significado que as pessoas concedem para aquilo que fazem, a concorrer tanto para a constituição da identidade individual quanto para a constituição da identidade coletiva. 


\section{REFERÊNCIAS BIBLIOGRÁFICAS}

AMANN, Safira Bezerra. Ideologia do desenvolvimento de comunidade no Brasil. 6.ed. São Paulo: Cortez, 1987.

Anuário Estatístico do Estado do Rio de Janeiro. Rio de Janeiro: Centro de Informações e Dados do Rio de Janeiro, ano I, 1998.

ARAÚJO, Eneida Maria Terra. Os mecanismos de ação coletiva na gestão da escola pública. São Paulo, 1997. Dissertação de Mestrado, FEUSP.

Atlas do Desenvolvimento Humano no Brasil - CD-ROM. Programa das Nações

Unidas para o Desenvolvimento - PNUD/ Instituto de Pesquisa Econômica e Aplicada - IPEA/ Fundação João Pinheiro - FJP/ Fundação Instituto Brasileiro de Geografia e Estatística - IBGE. 1998.

AVANCINE, Sérgio Luís. "Daqui ninguém nos tira": mães na gestão colegiada da escola pública. São Paulo, 1990. Dissertação de Mestrado, PUC-SP.

BEISIEGEL, Celso de Rui. Ação política e expansão da rede escolar. Pesquisa e Planejamento, São Paulo, n.8, dezembro de 1964, p.99-198.

BERGER, Peter, BERGER, Brigitte e KELLNER, Hansfried. La pluralizzazione del mondi della vita. In: SCIOLLA, Loredana. Identità: percorsi di analisi in sociologia. Torino: Rosenberg e Sellier, 1983.

BERGER, Peter L. e LUCKMANN, Thomas. A construção social da realidade. 12.ed. Petrópolis: Vozes, 1995

BERKENBROCK, Margarete May. Conselho de escola: um aprendizado democrático no país das excludências. São Paulo, 1993. Dissertação de Mestrado, PUC-SP.

BEZERRA, Ada Augusta Celestino. Gestão democrática da construção de uma proposta curricular no ensino público: a Experiência de Aracaju. São Paulo, 1997. Tese de Doutorado, FEUSP.

BOBBIO, Norberto. O futuro da democracia; uma defesa das regras do jogo. Trad. Marco Aurélio Nogueira. 6.ed. Rio de Janeiro: Paz e Terra, 1997.

BOMFIM, Maria do Carmo Alves do. Lutas populares pela escola pública e gratuita em Teresina (o caso dos bairros Lourival Parente e Vila São Francisco/Sul). São Paulo, 1991. Dissertação de Mestrado, PUC-SP.

BRANT, Vinícius Caldeira. Da resistência aos movimentos sociais: a emergência das classes populares em São Paulo. In: SINGER, Paul e BRANT, Vinícius C. (Org.). São Paulo: o povo em movimento. 2.ed. Petrópolis: Vozes/CEBRAP, 1981. 
BRITO, Tânia Maria Rezende. Uma proposta de administração educacional participativa e democrática. Rio de Janeiro, 1992. Dissertação de Mestrado, UFRJ.

BUENO, Belmira Amélia de Barros Oliveira. As associações de pais e mestres na escola pública do estado de São Paulo (1931-1986). São Paulo, 1987. Tese de Doutorado, FEUSP.

BUENO, Míriam Rezende. A relação família e escola: um diálogo possível? Belo Horizonte, 1994. Dissertação de Mestrado, UFMG.

CALAÇA, Celina Ferreira. Eleição de diretor de escolas e gestão democrática (um estudo de caso). São Paulo, 1993. Dissertação de Mestrado, PUC-SP.

CALDAS, Ana Maria Alves R. Gestão da escola e luta por educação escolarizada e não-escolar: processos interdependentes. São Paulo, 1995. Dissertação de Mestrado, PUC-SP.

CALIL, Elisa Silingowschi. Escola sem grade: um passo além da participação comunitária. São Paulo, 1994. Dissertação de Mestrado, PUC-SP.

CAMARGO, Rubens Barbosa de. Gestão democrática e nova qualidade de ensino: o Conselho de Escola e o Projeto de Interdisciplinaridade nas escolas municipais da cidade de São Paulo (1989-1992). São Paulo, 1997. Tese de Doutorado, FEUSP.

CAMPOS, Maria M.Malta. Escola e participação popular: a luta por educação elementar em dois bairros de São Paulo. São Paulo, 1982. Tese de Doutorado, FFLCH /USP.

CAMPOS, Maria M.Malta. As lutas sociais e a educação. Cadernos de Pesquisa, São Paulo, n.79, nov.1991, p.56-64.

CAMPOS, Rogério Cunha. A luta dos trabalhadores pela escola. São Paulo: Edições Loyola, 1989. (Coleção Educação Popular, n.10).

CAMPOS, Rogério Cunha. Cenas da educação brasileira: lutas sociais e desgoverno nos anos 80 na Grande Belo Horizonte. São Paulo, 1992. Tese de Doutorado, FEUSP.

CARDOSO, Ruth C.L. Movimentos sociais urbanos: balanço crítico. In: SORJ, Bernardo e ALMEIDA, Maria Hermínia T. de (Org.). Sociedade e política no Brasil pós-64. 2.ed. São Paulo: Brasiliense, 1984.

CARDOSO, Ruth C.L. Movimentos sociais na América Latina. Revista Brasileira de Ciências Sociais, São Paulo, n.3, vol.1, fevereiro de 1987. 
CARDOSO, Ruth C.L. Apresentação. In: KOWARICK, Lúcio (Org.). As lutas sociais e a cidade. São Paulo: passado e presente. Rio de Janeiro: Paz e Terra, 1988.

CARDOSO, Ruth C.L. A trajetória dos movimentos sociais. In: DAGNINO, Evelina (Org.). Os anos 90: política e sociedade no Brasil. São Paulo: Brasiliense, 1994.

CARVALHO, Cecília de. Conselho de escola: um caminho para a participação? São Paulo, 1991. Dissertação de Mestrado, PUC-SP.

CARVALHO, Marília Pinto de. Uma identidade plural: estudo de uma escola pública na região metropolitana de São Paulo. São Paulo, 1991. Dissertação de Mestrado, FEUSP.

CARVALHO, Marília Pinto de. Entre a casa e a escola: educadoras de $1^{\circ}$ grau na periferia de São Paulo. Revista Brasileira de Estudos Pedagógicos, Brasília, v.76, n.184, set./dez.1995, p.407-444.

CARVALHO, Marília Pinto de. Ensino, uma atividade relacional. São Paulo: mimeo., [1999?]

CARVALHO, Marília P.de e VIANNA, Cláudia P. Educadoras e mães de alunos: um (des)encontro. In: BRUSCHINI, Cristina e SORJ, Bila (Org.). Novos olhares: mulheres e relações de gênero no Brasil. São Paulo: Marco Zero/Fundação Carlos Chagas, 1994.

CARVALHO, Marília P.de e VIANNA, Cláudia P. Movimentos sociais por educação: a invisibilidade dos gêneros. Cadernos de Pesquisa, São Paulo, n.93, maio 1995, p.32-39.

CHAUÍ, Marilena. Conformismo e resistência. 6.ed. São Paulo: Brasiliense, 1994.

CISESKI, Ângela Antunes. Aceita um conselho? Teoria e prática da gestão participativa na escola pública. São Paulo, 1997. Dissertação de Mestrado, FEUSP.

CONNELL, Robert W. Políticas da masculinidade. Educação \& Realidade, Porto Alegre, v.20, n.2, jul./dez.1995, p.185-206.

CORRÊA, Rosa Lydia Teixeira. Administração participativa: realidade ou mito? Um estudo de caso. Campinas, 1991. Dissertação de Mestrado, UNICAMP.

CRAVO, Terezinha Baldassini. A participação popular no contexto microssocial do bairro Maria Ortiz. Vitória, 1995. Dissertação de Mestrado, UFES.

DAMATTA, Roberto. A casa e a rua. 5.ed. Rio de Janeiro: Rocco, 1997.

Dicionário de Ciências Sociais. Rio de Janeiro: Editora da Fundação Getúlio Vargas, 1986. 
Dimensões das carências sociais: informações municipais. Instituto Brasileiro de Geografia e Estatística - IBGE/ Instituto de Pesquisa Econômica e Aplicada IPEA. Rio de Janeiro: IBGE/IPEA, 1996, 27 v.

DOURADO, Luiz Fernandes. Democratização da escola: eleições de diretores, um caminho? Goiânia, 1990. Dissertação de Mestrado, UFG.

DUBET, François. Les lycéens. Paris: Éditions du Seuil, 1991.

DURHAM, Eunice R. Movimentos sociais - a construção da cidadania. Novos Estudos Cebrap, São Paulo, n.10, out.1984, p.24-30.

EVERS, Tilman. Identidade, a face oculta dos novos movimentos sociais. Novos Estudos Cebrap, São Paulo, n.4, abr.1984, p.11-23.

EZPELETA, Justa e ROCKWELL, Elsie. Pesquisa participante. São Paulo: Cortez/Autores Associados, 1989.

FAGUNDES, Vera Lúcia dos Passos. O pensar e o fazer na organização do trabalho na escola: análise crítica da experiência de gestão compartilhada na escola básica "Alberto Schmitt" - Região de Itajaí/SC. São Paulo, 1997. Dissertação de Mestrado, PUC-SP.

FÉLIX, Maria de Fátima Costa. Administração de empresa e administração escolar administração científica? Uma análise da proposta do estado capitalista brasileiro para burocratização do sistema escolar. Campinas, 1982. Dissertação de Mestrado, UNICAMP.

FERNANDES, Florestan (Org.). Comunidade e sociedade: leituras sobre problemas conceituais, metodológicos e de aplicação. São Paulo: Companhia Editora Nacional/ Ed.da Universidade de São Paulo, 1973.

FERNANDES, Mônica Abranches. Colegiado escolar: espaço de participação da comunidade. Campinas, 1998. Dissertação de Mestrado, UNICAMP.

FISCHER, Nilton Bueno. Movimentos sociais e educação: uma reflexividade instituinte. In: HYPOLITO, Álvaro Moreira e GANDIN, Luís Armando (Org.). Educação em tempos de incertezas. Belo Horizonte: Autêntica, 2000.

FLORES, Daniel Garcia. Conselho de Escola: possibilidades e limitações (um estudo de caso). Marília, 1996. Dissertação de Mestrado, UNESP.

FORTUNA, Maria Lucia de Abrantes. A democratização da gestão na escola pública: uma possibilidade de reflexão sobre seus condicionantes subjetivos. São Paulo, 1997. Tese de Doutorado, FEUSP. 
FORTUNATO, Marina Pinheiro. O desafio da gestão participativa na escola pública no estado de São Paulo e o desencontro do sistema central burocratizado: 1991-1995. São Paulo, 1998. Dissertação de Mestrado, PUC-SP.

FREYER, Hans. Comunidade e sociedade como estruturas histórico-sociais. In: FERNANDES, Florestan (Org.). Comunidade e sociedade - leituras sobre problemas conceituais, metodológicos e de aplicação. São Paulo: Companhia Editora Nacional/ Ed.da Universidade de São Paulo, 1973.

FRIEDMAN, Debra e McADAM, Doug. Collective identitity and activism. In: MORRIS, Aldon D. e MUELLER, Carol M. (Ed.). Frontiers in social movement theory. New Haven: Yale University Press, 1992.

FUCHS, Carlitos Kurdt. Luta dos (as) trabalhadores (as) pela escola pública em São Leopoldo. Porto Alegre, 1992. Dissertação de Mestrado, UFRGS.

GANZELI, Pedro. Estruturas participativas na cidade de Campinas. Campinas, 1993. Dissertação de Mestrado, UNICAMP.

GARCIA, Teise de Oliveira Guaranha. Gestão democrática: desafios para a ação coletiva em uma escola pública de Diadema. São Paulo, 1995. Dissertação de Mestrado, FEUSP.

GENOVEZ, Maria Salete. Conselho de escola: espaço para o exercício da participação? Um estudo de caso. Campinas, 1993. Dissertação de Mestrado, UNICAMP.

GHANEM JR., Elie George G. Lutas populares, gestão e qualidade da escola pública. São Paulo, 1992. Dissertação de Mestrado, FEUSP.

GHANEM JR., Elie George G. (Org.) Participação popular na gestão escolar bibliografia. São Paulo: Ação Educativa. 1995.

GOHN, Maria da Glória. A força da periferia. Petrópolis: Vozes, 1985.

GOHN, Maria da Glória. Teorias dos movimentos sociais - paradigmas clássicos e contemporâneos. São Paulo: Edições Loyola, 1997.

GONÇALVES, Maria Dativa de Salles. Dimensões críticas no estudo da especificidade da administração educacional. Curitiba, 1980. Dissertação de Mestrado, UFPR.

GONDRA, José Gonçalves. Quem traz o pé-de-moleque? A participação dos pais na gestão da escola pública. Rio de Janeiro, 1991. Dissertação de Mestrado, UFRJ.

GUERRA, Manoel Alves. Conselho de Escola: construindo a participação no país da exclusão. Campinas, 1998. Dissertação de Mestrado, UNICAMP. 
HORA, Dinair Leal da. Gestão democrática na escola. 4.ed. Campinas: Papirus, 1998.

JACOBI, Pedro. Movimentos sociais - teoria e prática em questão. In: SCHERERWARREN, Ilse e KRISCHKE, Paulo J. (Org.). Uma revolução no cotidiano? Os novos movimentos sociais na América Latina. São Paulo: Brasiliense, 1987.

JACOBI, Pedro. Movimentos sociais urbanos: os desafios da construção da cidadania. Cadernos do CEAS, Salvador, n.129, set./out.1990, p.34-44.

JOHNSTON, Hank, LARAÑA, Enrique e GUSFIELD, Joseph. Identities, grievances, and new social movements. In: LARAÑA, E., JOHNSTON, H. e GUSFIELD, J.R. (Ed.). New social movements - from ideology to identity. Filadélfia: Temple University Press, 1994.

LAMAS, Marta. Cuerpo e identidad. In: ARANGO, Luz; LÉON, Magdalena; VIVEROS, Mara (Orgs.) Género e identidad: ensayos sobre lo femenino y lo masculino. Colômbia: FCU/UNC, 1995, p.61-81.

LOURENÇO FILHO. Introducção ao estudo da Escola Nova. São Paulo: Melhoramentos, 1930.

LÜDKE, Menga e ANDRÉ, Marli E.D.A. Pesquisa em educação: abordagens qualitativas. São Paulo: EPU, 1986.

MACIEL, Maria José de Oliveira. Gestão escolar democrática. Os Conselhos Escolares na Rede Municipal de Ensino do Recife. Recife, 1995. Dissertação de Mestrado, UFPE.

MANSANO FILHO, Ricardo, OLIVEIRA, Romualdo Portela de, CAMARGO, Rubens Barbosa de. Tendências da matrícula no ensino fundamental regular no Brasil. In: OLIVEIRA, Cleiton de e outros. Municipalização do ensino no Brasil: algumas leituras. Belo Horizonte: Autêntica. 1999.

MARKUS, Maria Elsa. Conselho de Pais e Mães: o desafio participativo numa proposta de democratização da escola pública. Cuiabá, 1997. Dissertação de Mestrado, UFMT.

MARTINS, José de Souza. Caminhada no chão da noite - emancipação política e libertação nos movimentos sociais no campo. São Paulo: Hucitec, 1989.

MATTOS, Lúcia Alves Faria. Democracia e colegiado de escola: qual democracia? Um estudo da gestão colegiada em Minas Gerais. Rio de Janeiro, 1998. Tese de Doutorado, UFRJ. 
McCARTHY, John D. e ZALD, Mayer N. Resource mobilization and social movements: a partial theory. American Journal of Sociology, Chicago, vol.82, n.6, may 1977, p. 1212-1241.

MEAD, George H. Mind, self and society. Chicago: University of Chicago Press, 1934.

MELO, Maria de Fátima Gomes de. Ação integradora escola-família-comunidade: um estudo de caso. Rio de Janeiro, 1981. Dissertação de Mestrado, UFRJ.

MELO FILHA, Elisabeth Francisca de. Gestão escolar colegiada. Conselho Escolar e outros mecanismos democráticos: um caso em Pernambuco. João Pessoa, 1998. Dissertação de Mestrado, UFPB.

MELUCCI, Alberto. Sul coinvolgimento individuale nell'azione colletiva. Rassegna italiana di sociologia, ano XXVIII, n.1, genn.marzo, 1987, p.29-53.

MELUCCI, Alberto. L'invenzione del presente: movimenti sociali nelle società complesse. Bologna: il Mulino, 1991.

MELUCCI, Alberto. Il gioco dell'io: il cambiamento di sé in uma società globale. Milano: Saggi/Feltrinelli, 1992.

MELUCCI, Alberto. A experiência individual na sociedade planetária. Revista Lua Nova. São Paulo: CEDEC, n.38, 1996, p.199-221.

MELUCCI, Alberto. Movimentos sociais e sociedade complexa. Cadernos do Núcleo de Estudos e Pesquisa sobre movimentos sociais: Movimentos sociais na contemporaneidade. São Paulo: PUC - Serviço Social, n.2, abr.1997a, p.11-32.

MELUCCI, Alberto. Sociedade complexa, identidade e ação coletiva - entrevista a Dalila M.Pedrini e Adrian O.Scribano. Cadernos do Núcleo de Estudos e Pesquisa sobre movimentos sociais: Movimentos sociais na contemporaneidade. São Paulo: PUC - Serviço Social, n.2, abr.1997b, p.33-63.

MELUCCI, Alberto. Culture in gioco. Differenze per convivere. Milano: il Saggiatore, 2000.

MERCADO, Ruth. Una reflexión critica sobre la noción "escuela-comunidad". In: MERCADO, Ruth e ROCKWELL, Elsie. La escuela, lugar del trabajo docente: descripciones y debates. México: Departamento de Investigaciones Educativas, 1983.

MICHELAT, Guy. Sobre a utilização da entrevista não-diretiva em sociologia. In: THIOLLENT, Michel J.M. Crítica metodológica, investigação social e enquete operária. 5.ed. São Paulo: Editora Polis, 1987. 
MIRANDA, Graziela Alves. Descentralização e democratização da educação: um estudo em escolas públicas baianas. Salvador, 1998. Dissertação de Mestrado, UFBA.

MOISÉS, José Álvaro. Classes populares e protesto urbano. Tese de Doutorado, 1978. São Paulo: FFLCH/USP.

MOLL, Jaqueline. Redes sociais e processos educativos: um estudo dos nexos da educação de adultos com o movimento comunitário e as práticas escolares no Morro Alegre (Porto Alegre). Porto Alegre, 1998. Tese de Doutorado, UFRGS.

MONTENEGRO, Neísse. O conselho de escola e a gestão participativa. São Paulo, 1991. Dissertação de Mestrado, PUC-SP.

NISBET, Robert A. Comunidade. In: FORACCHI, Marialice M. e MARTINS, José de Souza (compilação de textos por) Sociologia e sociedade: leituras de introdução à sociologia. 14 tiragem. Rio de Janeiro: Livros Técnicos e Científicos Editora Ltda., 1990.

NOVAES, Ivan Luiz. A democratização da gestão da educação - um estudo da eleição de diretores e vice-diretores das escolas da rede municipal de ensino de Salvador. Salvador, 1996. Dissertação de Mestrado, UFBA.

OLIVEIRA, Ana Angélica Rodrigues de. A eleição para diretores e a gestão democrática da escola pública: uma reflexão sobre suas possibilidades e limitações. Rio de Janeiro, 1994. Dissertação de Mestrado, UFRJ.

OLIVEIRA, Cleusa Couto de. Planejamento educacional participativo: uma experiência de democratização do ensino público, em Lages - SC. Porto Alegre, 1988. Dissertação de Mestrado, PUC-RS.

OLIVEIRA, Francisco de. Os direitos do antivalor: a economia política da hegemonia imperfeita. Petrópolis: Vozes, 1998.

OLIVEIRA, Maristela Costa de. Participação da família na escola: possibilidades, limites, alternativas. Porto Alegre, 1998. Dissertação de Mestrado, PUC-RS.

OSORES, Norma J. Fuller. Identidades masculinas: varones de classe media em el Peru. Lima: PUC-Peru, 1997, p.17-47.

PALHARES, Marina Silveira. Movimentos comunitários urbanos em São Carlos: a conquista da cidadania num universo relacional. São Paulo, 1995. Tese de Doutorado, FEUSP. 
PARO, Vitor Henrique. Gestão da escola pública: alguns fundamentos. Subsídios para os encontros regionais. XIV Congresso Estadual de Educação. São Paulo, Apeoesp, 1995, p.4-5.

PARO, Vitor Henrique. Administração escolar: introdução crítica. 7.ed. São Paulo: Cortez, 1996a.

PARO, Vitor Henrique. Eleição de diretores: a escola pública experimenta a democracia. Campinas: Papirus, 1996 b.

PARO, Vitor Henrique. Gestão democrática da escola pública. São Paulo: Ática, 1997.

PARO, Vitor Henrique. Parem de preparar para o trabalho!!! Reflexões acerca dos efeitos do neoliberalismo sobre a gestão e o papel da escola básica. In: FERRETTI, Celso J.; SILVA JR., João dos Reis; OLIVEIRA, Maria Rita N.Sales (Org.) Trabalho, formação e currículo: para onde vai a escola? São Paulo: Xamã, 1999.

PARO, Vitor Henrique. Qualidade do ensino: a contribuição dos pais. São Paulo: Xamã, 2000.

PARO, Vitor Henrique. Reprovação escolar: renúncia à educação. São Paulo: Xamã, 2001.

PARSONS, Talcott. Il ruolo dell'identità nella teoria generale dell'azione. In: SCIOLLA, Loredana. Identità: percorsi di analisi in sociologia. Torino: Rosenberg e Sellier, 1983.

PASSOS, Inah, CARVALHO, Marília e SILVA, Zoraide I. Faustinoni da. Uma experiência de gestão colegiada. Cadernos de Pesquisa, São Paulo, n.66, ago.1988, p. 81-94.

PATTO, Maria Helena Souza. A produção do fracasso escolar. São Paulo: T.A.Queiroz, 1996.

PAZETO, Antonio Elizio. Processo decisório e participação comunitária no planejamento da educação: a experiência catarinense. Rio de Janeiro, 1988. Dissertação de Mestrado, IESAE/FGV.

PEPE, Theresa M.de Freitas Adrião. A gestão democrática nas escolas da rede municipal de São Paulo: 1989-1992. São Paulo, 1995. Dissertação de Mestrado, FEUSP.

PEREIRA, Luiz. A escola numa área metropolitana: crise e racionalização de uma empresa pública de serviços. São Paulo: Pioneira/ EDUSP, 1967. 
PESENTE, José Carlos. O colegiado escolar: avanços e limites na construção de uma escola democrática. Campo Grande/MS, 1995. Dissertação de Mestrado, UFMS.

PINTO, José Marcelino de Rezende. Administração e liberdade: um estudo do Conselho de Escola à luz da teoria da ação comunicativa de Jürgen Habermas. Campinas, 1994. Tese de Doutorado, UNICAMP.

PIZA, Edith. As professoras: o fazer-se de um ofício; contaminação de práticas no trabalho de magistério: notas para reflexão. Projeto História, São Paulo, n.11, novembro de 1994.

PIZZORNO, Alessandro. Identità e interesse. In: SCIOLLA, Loredana. Identità: percorsi di analisi in sociologia. Torino: Rosenberg e Sellier, 1983.

PRAIS, Maria de Lourdes Melo. Administração colegiada e prática pedagógica progressista na escola pública mineira. São Paulo, 1987. Dissertação de Mestrado, PUC-SP.

QUEIROZ, Imar Domingos. Governos locais, participação e reivindicações populares por educação escolar em Cuiabá. Cuiabá, 1998. Dissertação de Mestrado, UFMT.

REIS, Léa de Carvalho. Eleições de diretores e democratização da educação: a experiência do município do Rio de Janeiro. Rio de Janeiro, 1995. Dissertação de Mestrado, UFRJ.

REVILLA BLANCO, Marisa. El concepto de movimiento social: acción, identidad y sentido. Zona Abierta, n.69, 1994, p.181-213.

RIBEIRO, Heloisa Wallau Souto. Escola, pra que te quero? Um estudo de caso sobre as relações entre a escola pública e os pais de classes populares. Porto Alegre, 1992. Dissertação de Mestrado, UFRGS.

RIBEIRO, Maria das Graças M. Movimentos sociais urbanos, educação e hegemonia: a luta das associações de moradores por educação escolar. Rio de Janeiro, 1990. Dissertação de Mestrado, IESAE/FGV-RJ.

RIBEIRO, Maria Stella Mendes. Da democracia concedida à democracia desejada: o significado da luta por escola no Bairro Paulo VI de Belo Horizonte. Belo Horizonte, 1986. Dissertação de Mestrado, UFMG.

RIO DE JANEIRO (Estado). Secretaria de Estado de Planejamento. Secretaria de Estado de Desenvolvimento Econômico e Turismo. Plano Diretor de Turismo Relatório Executivo, agosto de 1999. 
ROMANELli, Otaíza de Oliveira. História da educação no Brasil (1930-1973). 11.ed. Petrópolis: Vozes, 1989.

ROSAS, Lúcia Barreto Collares. A transformação do colegiado de uma escola estadual de Minas Gerais: um aprendizado de democratização. Rio de Janeiro, 1988. Dissertação de Mestrado, UFRJ.

RUSSO, Miguel Henrique. Teoria e prática da administração escolar: confluências e divergências. São Paulo, 1995. Tese de Doutorado, FEUSP.

SADER, Eder. Quando novos personagens entraram em cena: experiências, falas e lutas dos trabalhadores da Grande São Paulo, 1970-1980. 3.reimpressão. Rio de Janeiro: Paz e Terra, 1995.

SALES, Josete de Oliveira Castelo Branco. A proposta de gestão colegiada no cotidiano da escola pública. Fortaleza, 1993. Dissertação de Mestrado, UFC.

SAMARTINI, Luci Silva. Direito de voz: a participação de pais e alunos na gestão da escola pública de $1^{\circ}$ e $2^{\circ}$ graus - perspectivas. São Paulo, 1994. Tese de Doutorado, FEUSP.

SANTOS, Manira Aboud. Educação e democracia no governo democrático-popular da cidade de São Paulo (1989-1992). São Paulo, 1997. Tese de Doutorado, FEUSP.

SANTOS, Rita Maria Maciel. Avaliação do desempenho do colegiado das escolas de Juiz de Fora. Rio de Janeiro, 1987. Dissertação de Mestrado, UFRJ.

SCHERER-WARREN, Ilse. O caráter dos novos movimentos sociais. In: SCHERERWARREN, Ilse e KRISCHKE, Paulo J. (Org.). Uma revolução no cotidiano? Os novos movimentos sociais na América Latina. São Paulo: Brasiliense, 1987.

SCHNEIDER, Ledi. Município, escolas e comunidade escolar integrados - uma proposta participativa em construção. Porto Alegre, 1997. Dissertação de Mestrado, PUC-RS.

SCIOLLA, Loredana. Teorie dell'identità. In: SCIOLLA, Loredana. Identità: percorsi di analisi in sociologia. Torino: Rosenberg e Sellier, 1983.

SCOTT, Joan. Gênero: uma categoria útil de análise histórica. Educação \& Realidade, Porto Alegre, v.20, n.2, jul./dez.1995, p.71-99.

SILVA, Dener Luiz da. Interações sociais no Conselho de Escola: o estudo de um caso. São Paulo, 1996. Dissertação de Mestrado, PUC-SP.

SILVA, Jair Militão da. Democracia e educação: a alternativa da participação popular na administração escolar. São Paulo, 1989. Tese de Doutorado, FEUSP. 
SILVA, Lázara Cristina da. Participação e sucesso escolar: construções cotidianas. Brasília, 1998. Dissertação de Mestrado, UnB.

SILVA, Luís A. Machado da e RIBEIRO, Ana Clara T. Paradigma e movimento social: por onde andam nossas idéias? Ciências Sociais Hoje, São Paulo, ANPOCS/Cortez, 1985, p.318-336.

SIQUEIRA, Sena A.de. A participação da comunidade na gestão de escolas no Distrito Federal - A Teoria e A Prática: confluência ou conflito? Brasília, 1998. Dissertação de Mestrado, UnB.

SOUSA, Leliana Santos de. O imaginário social e o movimento de mães e pais na escola pública estadual. Salvador, 1996. Dissertação de Mestrado, UFBA.

SOUZA, Edmar Pereira de. Participação dos pais e gestão escolar: o caso da escola Aureolina Eustácia Ribeiro, Cuiabá/MT. Cuiabá, 1996. Dissertação de Mestrado, UFMT.

SPÓSITO, Marília P. O povo vai à escola: a luta popular pela expansão do ensino público em São Paulo. São Paulo: Edições Loyola, 1984. (Coleção Educação Popular, n.2).

SPÓSITO, Marília P. Redefinindo a participação popular na escola. In: RIBEIRO, Vera Masagão (Org.). Participação popular e escola pública. São Paulo, jan.1989. (Cadernos do CEDI, n.19)

SPÓSITO, Marília P. A ilusão fecunda: a luta por educação nos movimentos populares. São Paulo: Hucitec / EDUSP, 1993.

STAKE, Robert E. Pesquisa qualitativa/naturalista - problemas epistemológicos. Educação e Seleção, São Paulo, n.7, jun.1983, p.19-27.

TELlES, Vera da Silva. A experiência do autoritarismo e práticas instituintes : os movimentos sociais em São Paulo nos anos 70. São Paulo, 1984. Dissertação de Mestrado, FFLCH/USP.

TELLES, Vera da Silva. Movimentos sociais - reflexões sobre a experiência dos anos 70. In: SCHERER-WARREN, Ilse e KRISCHKE, Paulo J. (Org.). Uma revolução no cotidiano? Os novos movimentos sociais na América Latina. São Paulo: Brasiliense, 1987.

TELLES, Vera da Silva. Sociedade civil e a construção de espaços públicos. In: DAGNINO, Evelina (Org.). Os anos 90: política e sociedade no Brasil. São Paulo: Brasiliense, 1994. 
TÖNNIES, Ferdinand. Comunidade e sociedade como entidades típico-ideais. In: FERNANDES, Florestan (Org.). Comunidade e sociedade - leituras sobre problemas conceituais, metodológicos e de aplicação. São Paulo: Companhia Editora Nacional/ Ed.da Universidade de São Paulo, 1973.

TOURAINE, Alain. Production de la société. Paris: Seuil, 1973.

TOURAINE, Alain. I due volti dell'identità. In: SCIOLLA, Loredana. Identità: percorsi di analisi in sociologia. Torino: Rosenberg e Sellier, 1983.

TOURAINE, Alain. An introduction to the study of social movements. Social Research, New York, vol.52, n.4, 1985, p.749-787.

VALLA, Victor Vincent. A crise de interpretação é nossa: procurando compreender a fala das classes subalternas. Educação e Realidade, Porto Alegre, v.21, n.2, jul./dez.1996, p.177-190.

VIANNA, Cláudia Pereira. O sonho que nos move: mães de alunos do Movimento Pró-Educação na luta pela melhoria do ensino público. São Paulo, 1992. Dissertação de Mestrado, PUC-SP.

VIANNA, Cláudia Pereira. Os nós do "nós": crise e perspectivas da ação coletiva docente em São Paulo. São Paulo: Xamã, 1999.

VIEIRA, Márcio F. Xavier. MAB: movimento social urbano e a luta pela educação. Rio de Janeiro, 1994. Dissertação de Mestrado, UERJ.

VILLELA, Delfina de Paiva. O conselho de escola: impasses, perspectivas e busca da participação. Campinas, 1997. Tese de Doutorado, UNICAMP.

VON GAL, Maria de Lourdes Gallo. Conselho de escola: a participação da comunidade na gestão administrativa e pedagógica da escola pública paulista de $1^{\circ}$ grau. São Carlos, 1991. Dissertação de Mestrado, UFSCar.

WEBER, Max. Comunidade e sociedade como estruturas de socialização. In: FERNANDES, Florestan (Org.). Comunidade e sociedade - leituras sobre problemas conceituais, metodológicos e de aplicação. São Paulo: Companhia Editora Nacional/ Ed.da Universidade de São Paulo, 1973.

WEFFORT, Francisco C. O populismo na política brasileira. 4.ed. Rio de Janeiro, Paz e Terra, 1989.

WEFFORT, Francisco C. Qual democracia? 2.reimpr. São Paulo: Companhia das Letras, 1996.

WIRTH, Louis. Delineamento e problemas da comunidade. In: FERNANDES, Florestan (Org.). Comunidade e sociedade - leituras sobre problemas conceituais, 
metodológicos e de aplicação. São Paulo: Companhia Editora Nacional/ Ed.da Universidade de São Paulo, 1973. 


\section{ANEXO \\ O PERFIL DOS ENTREVISTADOS}

\section{BETE}

Idade: 30 anos.

Casada, é manicure (trabalha a domicílio, e, ocasionalmente, consegue emprego em salão de cabeleireiro); o marido trabalha como segurança de vereador, já tendo sido vendedor em comércio.

Estudou até a $6^{\mathrm{a}}$ série.

Tem uma filha, Carla, de 10 anos, que está na $4^{a}$ série (estuda há três anos na escola).

Mora há quatro anos no bairro.

\section{CHICO}

Idade: 29 anos.

Casado, é um pequeno comerciante: tem um boteco, um "sacolão" e um mercadinho; a esposa é dona-de-casa.

Estudou até a $8^{\mathrm{a}}$ série.

Tem três filhos: Vanusa, de 4 anos; Josias, de 5 anos, que está na Classe de Alfabetização; e Shirlei, de 8 anos, que está na $2^{\mathrm{a}}$ série (os dois últimos sempre estudaram na Altino Malafaia).

Mora há dez anos no bairro.

\section{CIDA}

Idade: 41 anos.

Casada, é dona-de-casa, mas ajuda o orçamento doméstico vendendo roupa a domicílio; o marido é gerente de uma loja de autopeças.

Estudou até a $4^{\mathrm{a}}$ série.

Tem uma filha, Sueli, de 7 anos, que está na $1^{a}$ série (estuda desde o Pré-Escolar na Altino Malafaia).

Mora há dezesseis anos no bairro.

\section{ELISA}

Idade: 38 anos.

Casada, trabalha como auxiliar de produção em uma fábrica de fogos de artifício; o marido é chefe de cozinha em restaurante de cidade litorânea próxima.

Estuda na Altino Malafaia há dois anos (está na Etapa III da Educação de Jovens e Adultos).

Tem três filhos: Juliana, de 12 anos, que está na $6^{\text {a }}$ série; Adriana, de 15 anos, que está na $8^{\text {a }}$ série; e Saulo, de 17 anos, que abandonou a escola na $7^{\text {a }}$ série.

Mora há dezoito anos no bairro.

\section{IVETE}

Idade: 27 anos.

Casada, é dona-de-casa; o marido é operador de máquina em uma usina siderúrgica.

Estuda na Altino Malafaia há dois anos (na época da entrevista, acabara de completar a

Etapa IV da Educação de Jovens e Adultos); já havia estudado anteriormente na escola, onde fez a $5^{\mathrm{a}}$, a $6^{\mathrm{a}}$ e parte da $7^{\mathrm{a}}$ série. 
Tem dois filhos: Marcos, de 5 anos; e Gisela, de 9 anos, que está na $2^{\text {a }}$ série (estuda na Altino Malafaia desde o início da vida escolar).

É nascida e criada no bairro.

IVONE

Idade: 48 anos.

Casada, estava desempregada na ocasião da entrevista (já havia trabalhado, quando morava em outro município, em fábrica de costura); o marido trabalha ocasionalmente, quando surge algum tipo de serviço.

Estudou até a $3^{\text {a }}$ série.

Tem dois filhos: Janaína, de 11 anos, que está na $5^{\text {a }}$ série; e Carlos, de 17 anos, que está na Etapa III da Educação de Jovens e Adultos.

Mora há dois anos no bairro, mesmo período em que seus filhos freqüentam a escola.

\section{MARTA}

Idade: 33 anos.

Casada, é dona-de-casa; o marido é soldador maçariqueiro na Nuclep, indústria produtora de equipamentos pesados para usinas nucleares.

Estudou até a $6^{\mathrm{a}}$ série.

Tem dois filhos: Francisco, de 9 anos, que está na $2^{\mathrm{a}}$ série (estuda há um ano na escola); e Miguel, de 11 anos, que está na $5^{\text {a }}$ série (estuda há dois anos na escola).

Mora há onze anos no bairro.

\section{NEUSA}

Idade: 27 anos.

Casada, é dona-de-casa (já trabalhou como vigia na cozinha de uma firma); o marido trabalha em uma fábrica de manilhas.

Estudou até a $8^{\mathrm{a}}$ série.

Tem três filhos: Roberto, de seis meses; Tiago, de 5 anos, que está no Pré-Escolar em outra escola municipal; e Lúcia, de 8 anos, que está na $2^{a}$ série da Altino Malafaia.

Mora há oito anos no bairro.

\section{NICE}

Idade: 51 anos.

Casada, é dona-de-casa; o marido é empregado de empreiteira que presta serviços a uma indústria siderúrgica.

Estuda na Altino Malafaia há três anos (está na Etapa I da Educação de Jovens e Adultos).

Tem sete filhos, dois quais cinco fizeram todo o ensino fundamental na escola; a mais nova, Maria, de 13 anos, está na $5^{\text {a }}$ série.

Mora há onze anos no bairro.

ROSA

Idade: 40 anos.

Viúva (o marido morreu atropelado na rodovia federal), trabalha como empregada diarista; já trabalhou como caseira, vendendo queijo, lavando e passando roupa para fora.

Estuda na Altino Malafaia há três anos (está na Etapa II da Educação de Jovens e Adultos); anteriormente, nunca havia estudado. 
Tem três filhos: Edivaldo, de 16 anos, que está na $7^{\mathrm{a}}$ série; Emerson, de 17 anos; e Emília, de 19 anos (todos os três sempre estudaram na Altino Malafaia, sendo que os dois últimos já concluíram o ensino fundamental).

Mora há mais de dezoito anos no bairro.

\section{RUTE}

Idade: 28 anos.

Casada, é dona-de-casa, mas ajuda o orçamento doméstico vendendo roupa a domicílio; o marido trabalha ocasionalmente, quando surge algum tipo de serviço. Antes de mudarem para o bairro, ambos eram colonos no Espírito Santo.

Estudou até a $4^{\mathrm{a}}$ série.

Tem três filhos: José, de 10 anos, que está na $3^{\mathrm{a}}$ série; João, de 12 anos, que está na $4^{\mathrm{a}}$ série; e Joana, de 13 anos, que está na $5^{\text {a }}$ série.

Mora há quatro anos no bairro, mesmo período em que seus filhos freqüentam a escola.

\section{SEU CAMPOS}

Idade: 83 anos.

Casado, é aposentado, e tem ajuda financeira de seu filho mais velho, do primeiro casamento; sua segunda esposa, de 38 anos, é dona-de-casa.

Estudou até a $3^{\mathrm{a}}$ série.

Tem duas filhas do segundo casamento: Paula, de 15 anos, que está na $8^{\text {a }}$ série; e Júlia, de 16 anos, que está no $1^{\circ}$ ano do Ensino Médio em escola no centro de Itaguaí (Júlia fez todo o ensino fundamental na Altino Malafaia, o que é ainda o caso de Paula).

Mora há treze anos no bairro.

\section{ZEFA}

Idade: 30 anos.

Casada, é dona-de-casa; o marido trabalha no almoxarifado de um hotel em cidade litorânea próxima.

Estudou até a $6^{\mathrm{a}}$ série.

Tem três filhos: Glória, de 3 anos; Ronald, de 8 anos, que está na 2a série; e Elder, de 11 anos, que está na $3^{\text {a }}$ série (os dois filhos estão, desde o início da vida escolar, na Altino Malafaia, com exceção de um período de seis meses, em que residiam em outro município).

Mora há dezenove anos no bairro, com interrupções. 